US Army Corps

of Engineers

Waterways Experiment

Station

Natural Resources Research Program

\title{
Demand and Marketing Study at Army Corps of Engineers Day-Use Areas
}

\author{
by Stephen D. Reiling \\ University of Maine \\ Ronald E. McCarville \\ University of Waterloo \\ Christopher M. White
}

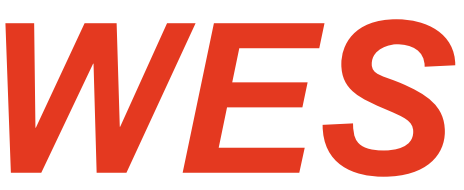

Approved For Public Release; Distribution Is Unlimited

Prepared for Headquarters, U.S. Army Corps of Engineers 
The contents of this report are not to be used for advertising, publication, or promotional purposes. Citation of trade names does not constitute an official endorsement or approval of the use of such commercial products.

The findings of this report are not to be construed as an official Department of the Army position, unless so designated by other authorized documents. 


\section{Demand and Marketing Study at Army Corps of Engineers Day-Use Areas}

by Stephen D. Reiling

Department of Resource Economics and Policy

University of Maine

Orono, ME 04469-5782

Ronald E. McCarville

Department of Recreation and Leisure Studies

University of Waterloo

Waterloo, Ontario N2L 3G1

Christopher M. White

U.S. Army Corps of Engineers

Waterways Experiment Station

3909 Halls Ferry Road

Vicksburg, MS 39180-6199

Final report

Approved for public release; distribution is unlimited 


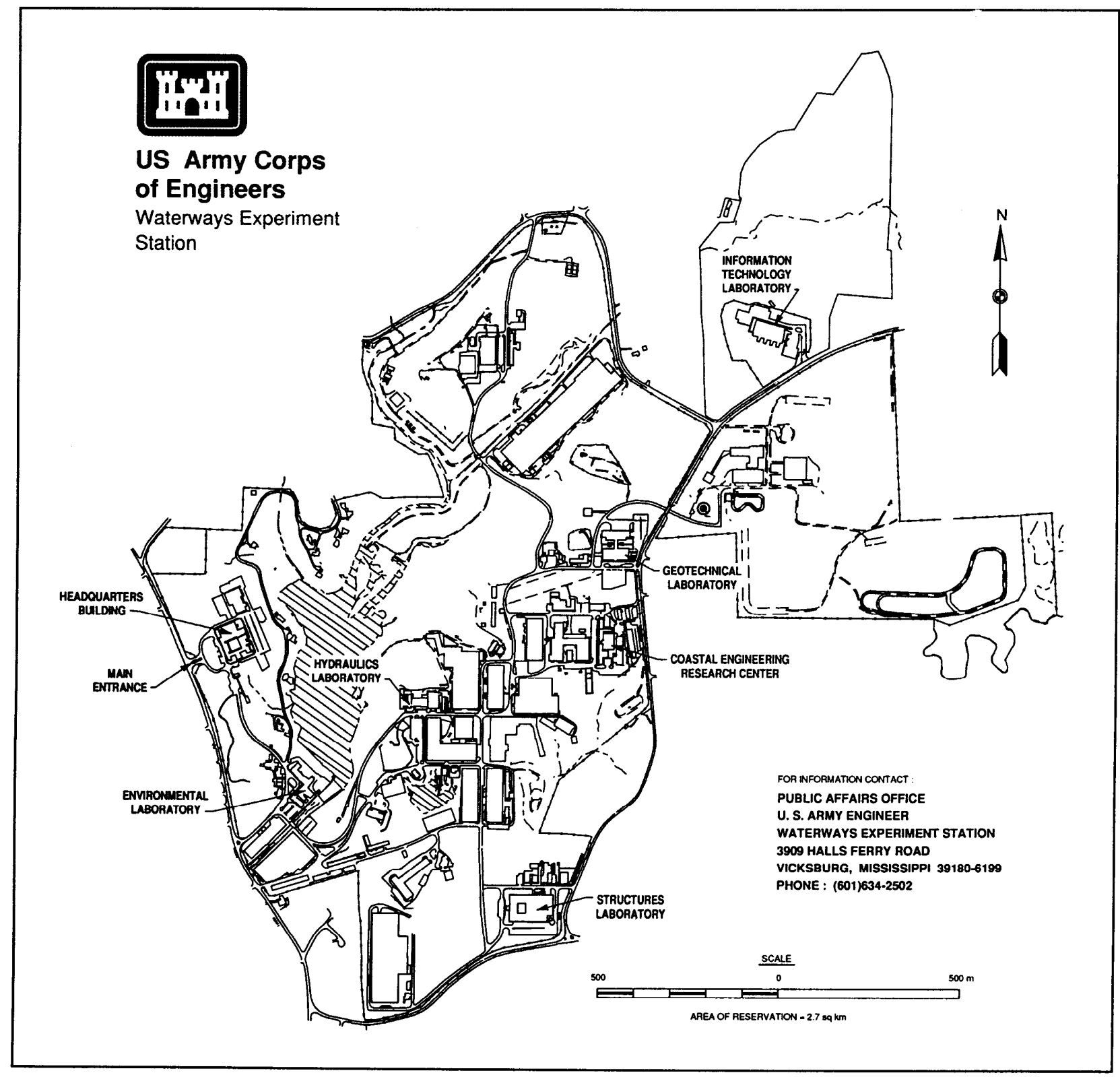

\section{Waterways Experiment Station Cataloging-in-Publication Data}

Reiling, Stephen C.

Demand and marketing study at Army Corps of Engineers day-use areas / by Stephen C. Reiling, Ronald E. McCarville, Christopher M.

White ; prepared for U.S. Army Corps of Engineers.

106 p. : ill. ; $28 \mathrm{~cm}$. - (Miscellaneous paper ; R-94-1)

Includes bibliographic references.

1. Recreation areas - Costs - Public opinion. 2. Outdoor recreation - Finance - Case studies. 3. Reservoirs - Recreational use - Fees. I. McCarville, Ronald E. II. White, Christopher M. III. United States. Army. Corps of Engineers. IV. U.S. Army Engineer Waterways Experiment Station. V. Natural Resources Research Program (US Army Corps of Engineers) VI. Title. VII. Series: Miscellaneous paper (U.S. Army Engineer Waterways Experiment Station) ; R-94-1. 


\section{Contents}

Preface $\ldots \ldots \ldots \ldots \ldots \ldots \ldots \ldots \ldots$ vi

Summary $\ldots \ldots \ldots \ldots \ldots \ldots \ldots \ldots \ldots$ viii

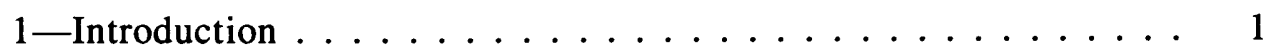

Background and Objectives . . . . . . . . . . . 1

Organization of Report $\ldots \ldots \ldots \ldots \ldots \ldots \ldots \ldots$

2-Study Procedures . . . . . . . . . . . . . . . 3

Selection of Corps Projects and Recreation Areas . . . . . . . 3

Data Collection Procedures . . . . . . . . . . . . . 4

Sampling Plan $\ldots \ldots \ldots \ldots \ldots \ldots \ldots \ldots$

3-User Profiles $\ldots \ldots \ldots \ldots \ldots \ldots \ldots \ldots \ldots$

Data Collection Results . . . . . . . . . . . . . . . 8

Sociodemographic and Trip Characteristics of Day Users .... . 9

4-Revenue Projections and Fee Impacts on Population Subgroups . . 12

Estimation of Fee Revenue . . . . . . . . . . . . . . . . . . 13

Fee Impacts on Population Subgroups . . . . . . . . . . . . 23

5-Respondent Motivations, Attitudes, and Expectations

Toward Fees . . . . . . . . . . . . . . . . . . . 27

Motivations to Visit Corps Site . . . . . . . . . . . . . . 27

Importance/Performance Analyses . . . . . . . . . . . . . . 27

Agreement with Fees . . . . . . . . . . . . . 30

Price Sensitivity . . . . . . . . . . . . . . . 34

6-Discussion and Recommendations . . . . . . . . . . . . 39

Recommendation I: Equity and the Charging of Fees . . . . . . 39

Recommendation I A . . . . . . . . . . . . . 40

Recommendation I B . . . . . . . . . . . . 40

Recommendation I C . . . . . . . . . . . . . . . 40

Recommendation I D . . . . . . . . . . . . . . . 40

Recommendation IE . . . . . . . . . . . . . 41 
Recommendation II: Value and the Setting of Fees . . . . . . . 41

Recommendation II A . . . . . . . . . . . . . . 41

Recommendation II B ................. 42

Recommendation III: Choice and the Setting of Fees . . . . . . 42

Recommendation III A . . . . . . . . . . . . 42

Recommendation III B ................ 43

Appendix A: Corps Day-Use Questionnaire . . . . . . . . . . . A1

Appendix B: Sampling Information ................... B1

Appendix C: Day-Use Survey Comments ........... C1

SF 298

\section{List of Tables}

Table 1. Projects and Day-Use Recreation Areas Included in the Corps Day-Use Fee Study . . . . . . . . . . . . . 4

Table 2. Day-Use Data Collection Results for the Corps Day-Use Fee Study, by Project . . . . . . . . . 8

Table 3. Sociodemographic Characteristics of Corps Day-Use Visitors, by Project . . . . . . . . . . . 10

Table 4. Trip Characteristics of Corps Day-Use Visitors, by Project . . . . . . . . . . . . . .

Table 5. Independent Variables Included in the Multinomial Logit Model . . . . . . . . . . . . . . . . 13

Table 6. Independent Variables Included in the Demand Model . . 15

Table 7. Maximum Likelihood Estimates for the Multinomial Logit Model . . . . . . . . . . . . . 16

Table 8. Ordinary Least Squares Estimates for the Demand Equation . . . . . . . . . . . . . 18

Table 9. Day-Use Areas Identified as Fees Areas by Corps Personnel, by Project . . . . . . . . . . .

Table 10. Projected Revenue at Alternative Fee Levels, Burnsville Project ............... 20

Table 11. Projected Revenue at Alternative Fee Levels, Strom Thurmond Project . . . . . . . . . . . 20

Table 12. Projected Revenue at Alternative Fee Levels, J. Percy Priest Project . . . . . . . . . . . . . 21

Table 13. Projected Revenue at Alternative Fee Levels, Truman Project $\ldots \ldots \ldots \ldots \ldots$ 
Table 14. Projected Revenue at Alternative Fee Levels,

Canyon Project ................ 21

Table 15. Projected Revenue at Alternative Fee Levels,

Mendocino Project . . . . . . . . . . . . 21

Table 16. Sociodemographic and Trip Characteristics of Corps

Day-Use Visitors, by Willingness to Pay Day-Use Fee . . 24

Table 17. Importance of Service and Facility Characteristics . . . 28

Table 18. Quality of Services and Facilities . . . . . . . . 29

Table 19. Level of Agreement with Statements Regarding

Prices Across Projects . . . . . . . . . . . . 31

Table 20. Mean Expected Prices for Boat and Picnic

Packages Across Projects . . . . . . . . . . . . 34 


\section{Preface}

The work reported herein was conducted as part of the Natural Resources Research Program (NRRP). The NRRP is sponsored by the Headquarters, U.S. Army Corps of Engineers (HQUSACE), and is assigned to the U.S. Army Engineer Waterways Experiment Station (WES) under the purview of the Environmental Laboratory (EL). Funding was provided under Department of the Army Appropriation No. 96X3121, General Investigation. The NRRP is managed under the Environmental Resources Research and Assistance Programs (ERRAP), Mr. J. L. Decell, Manager. Ms. Carolyn B. Schneider was Assistant Manager, ERRAP, for the NRRP. Technical monitors during this study were Mr. Robert Daniels and Ms. Judy Rice, HQUSACE.

The report was prepared by Dr. Stephen D. Reiling, University of Maine; Dr. Ronald McCarville, University of Waterloo; and Mr. Christopher M. White, Outdoor Recreation Planner, Resource Analysis Branch (RAB), EL. Review and comments were provided by Messrs. Scott Jackson and John Titre, RAB.

This report presents a comprehensive study on fees related to outdoor recreation. It was completed as one of the tasks for Work Unit 32745 , Measuring the Effects of Recreation Fee Programs. It represents a cooperative effort bridging the fields of economics and marketing. These insights could not have been gathered without the assistance of literally hundreds of individuals. The authors would like to thank the many Corps staff members, contractors, and Bicentennial Volunteers, Inc., personnel who assisted with the collection of this data. Special thanks to the staff at the Strom Thurmond Lake for their aid in pretesting the survey instruments and procedures early in the project and their assistance in all stages of the study.

The greatest debt is owed to the hundreds of Corps users who completed the surveys. The authors would like to thank them for their willingness to share their thoughts and feelings.

The authors also wish to thank all who helped in all stages of data collection and in the preparation of this final report. At the University of Maine, Carol Edgecomb, Steve Jacobs, Chris Robinson, Rod Bennett, Pam Kaval, and Ed Eshelman made important contributions to the project. 
Dr. Ty Cheng spent many hours on the econometric models used in the study. Linda Kupp, a graduate assistant at the University of Waterloo, provided ongoing assistance throughout the project.

The report was prepared under the general supervision of Mr. Scott Jackson, Acting Chief, RAB, EL; Mr. H. Roger Hamilton, Acting Chief, Natural Resources Division, EL; and Dr. John W. Keeley, Director, EL.

At the time of publication of this report, Director of WES was Dr. Robert W. Whalin. Commander was COL Bruce K. Howard, EN.

This report should be cited as follows:

Reiling, S. D., McCarville, R. E., and White, C. M. (1994). "Demand and marketing study at Army Corps of Engineers day-use areas," Miscellaneous Paper R-94-1, U.S. Army Engineer Waterways Experiment Station, Vicksburg, MS. 


\section{Summary}

Data concerning fees for outdoor recreation at Corps day-use areas and campgrounds were collected in the summer of 1993 at six Corps projects (Burnsville, Strom Thurmond, Truman, Canyon, and Mendocino). This report deals only with day-use fees. A separate report concerning campground fees is being prepared for submission at a later date.

The annual pass/daily fee combinations that yield the maximum revenue projections for the six projects range from $\$ 20 / \$ 3$ (J. Percy Priest Lake) to $\$ 50 / \$ 4$ (Canyon Lake). However, several of the other annual fee combinations produce close to that revenue with much lower fee combinations. Setting fees "too high" results in more lost revenue than setting fees "too low" at four of the six projects. At J. Percy Priest Lake, the fee combination of $\$ 50 / \$ 5$ results in estimated revenue of only $\$ 22,000$. The lowest fee combination of $\$ 10 / \$ 1$ results in estimated revenue of over $\$ 150,000$. The same pattern exists at Burnsville, Truman, and Mendocino Lakes.

The projections presented above are considered to be minimum estimates of annual fee revenues. First, users' responses to the three-choice fee question are based on their "behavioral intentions" rather than actual behavior. Many people who said they would stop using the Corps day-use areas if fees were implemented still expressed favorable quality and preference ratings for the sites. Second, the strong negative attitudes toward fees expressed by users seem to be based on philosophical grounds. Consequently, they may have behaved "strategically" by indicating they would not visit the Corps areas in the future if a fee system was implemented. Third, this survey only considered current users. There may well be current nonusers who would visit the day-use areas in the future, and thereby partially or completely offset the current users who will be displaced by the fee system.

Reports of commitment to Corps sites and perceptions of high service quality did not, however, correspond with willingness to pay fees. In spite of the overall positive attitudes and perceptions expressed by visitors, they generally expressed a very negative attitude toward fees at the day-use areas. Although the rejection of fees was quite pervasive, it was strongest at Burnsville, Truman, and Mendocino projects. It was more pervasive among frequent users than occasional users. 
The negative attitude toward fees was also expressed in terms of visitors' stated reaction to fees if implemented. Overall, over 41 percent of respondents stated they would no longer visit the Corps day-use areas if fees were charged. These users reported lower incomes and lower education levels than did the respondents who indicated they would pay a fee. Those unwilling to pay a fee also spent less time at the sites visited, traveled shorter distances to reach the sites, and expressed lower quality and preference ratings for the areas visited. On the other hand, they made many more trips to the day-use areas during the last year than did their counterparts who expressed a willingness to pay fees.

Survey results suggest that a fee system would not affect minority group users any more severely than nonminority users. However, the results consistently indicate that users with lower incomes would respond differently to fees than users with higher incomes. Specifically, a larger proportion of low-income users would stop visiting the site if a fee system was implemented. Furthermore, users with lower incomes were more sensitive to the magnitude of the fees charged. Higher fees would displace a higher proportion of the users with lower income levels.

Respondents reported that several issues were very important to them when they decided upon a day-use area. The most important of these issues were cleanliness of restrooms, adequate parking, friendliness of staff, scenery, swimming beaches, security patrols, and picnic tables near the beach. Passive activities enjoyed at the sites included relaxing and sunbathing, while swimming and fishing were most popular among active participants. Users were generally quite satisfied with the quality of these services now being provided at Corps sites. As a result, they often expressed strong commitment or loyalty to the sites.

Several recommendations are offered toward the establishment of dayuse fees: (a) the disposition of day-use fees that are collected need to be tied as much as possible to operation and maintenance of the specific dayuse area; (b) briefing the staff members in regard to the need for and disposition of the day-use fee will help bring about a more positive public support for the fee program; (c) initial setting of day-use fees at a conservative level may lead to some loss of revenue, but more importantly would lessen the initial resistance to day-use fees especially by lower income users; and (d) offering choices by setting fees based on the provision of services and facilities will lead to making the users feel they have options regarding the fee charged. 


\section{Introduction}

\section{Background and Objectives}

The Corps of Engineers provides recreational opportunities for millions of visitors each year. Like many public sector agencies, the Corps has expressed interest in diversifying its existing funding base. User fees are one means of achieving such diversification, and legislation was recently passed by Congress granting the Corps the authority to begin charging user fees at selected Corps day-use recreation areas. Unfortunately, little is known about how Corps day-use visitors may react to fees. Fees may cause considerable dissatisfaction among user groups. Such dissatisfaction is more likely when fees are introduced for the first time and may be expressed in complaint behavior, vandalism, or alienation and displacement of current users.

Public sector pricing initiatives are typically undertaken to maintain or improve current levels of service. Fees provide resources required to provide more and/or better services to user groups. Consequently, a balance between revenue and user satisfaction is the ultimate measure of success for any public sector pricing strategy. Successful fees are those that collect revenues with minimal displacement of users from the sites at which the fees were collected. However, fees often generate both negative and positive consequences simultaneously. The same fee that provides revenue and reduces crowding at popular recreation areas (thereby enhancing the experience of some users) may also displace loyal visitors. Further, fee increases designed to increase revenue may decrease use levels to such an extent that revenues are actually reduced. The key to effective pricing then is to develop pricing policies that anticipate and address user concerns before they arise. In this way, prices are least likely to generate dissatisfaction or displace large numbers of users.

The general goal of this project was to assess the potential effects of a fee program at Corps of Engineers day-use areas. Specifically, three objectives were pursued: (a) estimate the revenue that could be collected at these six Corps projects if a fee system was implemented; (b) determine whether specific subgroups within the population of current users would be more severely impacted by the proposed fee system than other current 
users; and (c) determine the attitudes, motivations, and expectations of Corps day users with regard to fees. Visitors to selected Corps day-use areas were surveyed and asked to consider many pricing issues and offer their personal preferences for various pricing strategies. Their responses are used to suggest how users will respond to the proposed fee system and to suggest how fees might best be instituted at Corps day-use sites.

The degree to which fees either encourage or discourage visitation is a function of user preferences and expectations, as well as the magnitude of the fee. Consequently, users' perceptions of Corps day-use areas were gathered. The survey instrument concentrated on (a) past experience/ knowledge; (b) importance/performance assessments of Corps sites; (c) preferences, expectations, and potential reactions to fees by individual users; and (d) sociodemographic characteristics. This information is used to provide insight into current users' expectations and their intentions should fees be initiated.

\section{Organization of Report}

The remainder of this report is comprised of four sections. In Chapter 2, an overview of the criteria used to select the projects included in the study is presented, along with a description of data collection procedures employed in the study. Chapter 3 offers results of the data collection process. In Chapter 4, revenue projections are presented along with the effects of fees on selected population subgroups. Chapter 5 includes an analysis of the data related to the attitudes, motivations, and perceptions of current users. Finally, Chapter 6 offers conclusions and recommendations from the study concerning fees at Corps day-use areas. 


\section{Study Procedures}

A brief description of the procedures used in the study is presented in this section. The criteria used to select the Corps projects and recreation areas used in the study are discussed first, followed by a description of the questionnaire development process. Finally, the data collection procedures used in the study are discussed. ${ }^{1}$

\section{Selection of Corps Projects and Recreation Areas}

Several criteria were used to evaluate and select the Corps projects used in the study. First, geographical diversity in terms of location within the United States was required to account for regional differences, if any, in users' attitudes toward fees and their willingness to pay fees at Corps day-use sites. Location of the projects relative to population centers was considered to ensure that both accessible and remote projects were included in the study. Project size (both land and water acreage) was also used as a criterion. Finally, the study addressed the question of fees' impact on different user groups. Consequently, sites were selected based on the potential for user group diversity in terms of activities pursued, age, income, and ethnic background.

The day-use recreation areas within the Corps projects also had to possess certain characteristics. First, the project had to contain at least two dayuse areas with the potential for implementing a day-use fee. Therefore, day-use areas had to contain beaches, picnic areas, and/or boat ramps; and visitation levels had to be sufficient to make a fee system cost-effective. The project also had to contain day-use areas that varied in terms of their level of development and the services they offered to users. The areas also had to have an adequate location where traffic could be safely intercepted. Finally, because surveys of both day users and campground users

1 Although a survey of Corps campers was performed in the study, this report only addresses the day-use portion of the study. The results of the camper survey will be included in a more comprehensive technical report. 
were planned, the project also had to contain Corps-operated campgrounds with varying levels of services and facilities available to campers.

A total of 18 Corps projects were visited during October and November of 1992 by the Corps representative who participated in the study. Geographically, the projects ranged from California to West Virginia. Each project was evaluated using the criteria outlined above. Based on the information collected at the projects and the onsite evaluation, the following six projects were selected for the study: Burnsville Lake (Huntington District), West Virginia; Strom Thurmond Lake (Savannah District) on the Georgia-South Carolina border; J. Percy Priest Lake (Nashville District), Tennessee; Truman Lake (Kansas City District), Missouri; Canyon Lake (Fort Worth District), Texas; and Mendocino Lake (Sacramento District), California. The specific day-use recreation areas selected for sample collection at the six projects are identified in Table 1.

\section{Table 1 \\ Projects and Day-Use Recreation Areas Included in the Corps Day-Use Fee Study}

\begin{tabular}{|l|l|}
\hline Project & Day-Use Areas \\
\hline Burnsville & Bulltown, Riffle Run \\
\hline Strom Thurmond & Clarks Hill, Lake Springs \\
\hline J. Percy Priest & Anderson Road, Cook \\
\hline Truman & Long Shoal, Shawnee Bend \\
\hline Canyon & Comal Park, Canyon Park \\
\hline Mendocino & Che-Ka-Ka, Pomo \\
\hline
\end{tabular}

\section{Data Collection Procedures}

The day-use survey instrument was developed over several months and was completed in mid-March of 1993. A preliminary draft of the instrument was reviewed by Corps personnel and revised accordingly. The questionnaire format was tested at Strom Thurmond in late April. Two focus groups were conducted and several changes were made, including wording changes to clarify questions and the removal of several questions to reduce the length of the instrument.

While at Strom Thurmond in late April, steps were also taken to pretest the data collection procedures described below. Names and addresses of 50 day-use visitors were collected by stopping their vehicles as they exited Lake Springs Recreation Area. Questionnaires were mailed about a week later to these 50 users. They were asked to complete the questionnaire and return it in the stamped envelope provided. Seventy-five percent of 
the questionnaires were completed and returned during this test of data collection procedures.

The final version of the survey instrument contained questions about the recreational activities in which respondents generally participated, the types of facilities and services they considered important, their assessment of the quality of the day-use area they visited, and specific information about their trip to the Corps recreation areas or campgrounds. Trip information included length of stay, distance traveled, and the number of people in the party. A series of questions was also included that probed respondents' attitudes toward fees and "fair" fee levels for facilities providing different levels of development or services. Sociodemographic information also was requested.

The day-use instrument contained questions related to the level of expenditures visitors made during the visit and the number of trips they made to the recreation area during the last 12 months. Finally, day users were asked how they would respond to a fee system at the Corps day-use area they visited and the number of trips they would make, if any, at alternative fee levels. These questions were used in the analysis presented below to estimate the impact of fees on different user groups and to project the revenue that could be generated by the fee system. A copy of the day-use survey is included in Appendix A of this report.

\section{Sampling Plan}

The major objective of the sampling plan was to obtain a representative random sample of current users of the day-use areas during the time period in which the survey was conducted. The sampling plan used to accomplish this is discussed briefly.

Based on the study's objectives and cost considerations, a target of 300 completed surveys was established for each of the six projects. With an assumed response rate of 65 percent, a sample size of 462 was adopted for each lake. The sample was collected between June 9 and July 5, 1993. The period July 6-12 was reserved for further sample selection if weather conditions prevented sample collection on selected days during the sampling period.

Visitation data (number of vehicles) for the months of July and August of 1992 were obtained for the day-use areas included in the study from the project using their best available data. ${ }^{1}$ Corps personnel also provided estimates of the percent of vehicles that visited on weekdays and weekends at the two selected day-use areas, and the percent of vehicles that departed

1 Because flooding affected 1992 and 1991 visitation levels, 1990 visitation data were used for Canyon Lake. 
the day-use areas during 4-hr time blocks between 6 a.m. and 10 p.m. on both weekends and weekdays. This information was used to allocate the total sample of 462 using the following procedures.

First, the total sample of 462 day-use vehicles or visitor parties was distributed among the two day-use areas in proportion to the number of vehicles entering the two sites in June and July 1992. That is, if Areas A and $B$ accounted for 60 percent and 40 percent, respectively, of the total number of the vehicles, then 60 percent of the sample was allocated to Area A, and 40 percent was allocated to Area $B$. The sample size at each recreation area was then distributed among weekdays and weekends using the information provided by Corps personnel at each project. Finally, the weekday and weekend sample sizes were allocated among the 4-hr time blocks based on the estimates of the percent of vehicles that depart the day-use areas during each period. The sample allocations for the six projects are shown in Appendix B, Table B1.

A schedule was constructed ${ }^{1}$ showing the area and time period in which names and addresses were to be collected on each day during the sampling period. Each weekday and weekend time period appeared twice in the schedule, with one-half of the sample names and addresses being collected during each of the two sessions. If weather conditions prevented sample collection on a given day and time period, the required number of names and addresses were to be collected on the same day and time period during the week reserved for that purpose. The weekday 4-hr time blocks were randomly assigned to the weekdays in the sampling period using a random numbers generator. For weekends, two nonsequential time blocks were paired, and the pairs were randomly assigned to the weekend days in the sampling period. The sampling schedules for the six projects are reported in Appendix B, Table B2.

Survey personnel were employed to collect the names and addresses for the sample at the selected day-use areas on the days and times indicated on the schedule. They were briefed on the purpose of the project and the procedures to be used to collect the sample names and addresses during a training session conducted at J. Percy Priest in late May of 1993.

Names and addresses for the day-use sample were obtained using traditional traffic-intercept procedures. The surveyors stopped randomly selected vehicles during each time period. Traffic-intercept procedures were used to minimize the potential for sample selection bias that could occur if visitors were contacted while in the day-use areas. For example, contacting visitors while in the day-use area may result in contacting fewer swimmers, boaters, or others actively engaged in activities during the time in which visitors were contacted.

1 Names and addresses for the sample were not collected on Tuesday or Wednesday during the sampling period, as these were scheduled days off for the personnel hired to collect this information. 
After explaining the purpose of the survey, potential respondents were given the opportunity to decline to participate in the study. If they agreed to take part, survey personnel collected the name, address, and other information about the visit from the driver. A sample of the data sheet completed for each potential respondent is shown in Appendix B, Table B3. Potential respondents were also given an introductory letter explaining the study in more detail and asking for their cooperation.

The data sheets filled out by survey personnel were mailed to the University of Maine every Monday during the sampling period. Questionnaires were mailed to potential respondents from the University of Maine, and completed surveys were mailed back to the University using the postage-paid address label provided. The Total Design Method for mail surveys was used to conduct the mail survey. ${ }^{1}$ A postcard reminder was mailed about 3 to 5 days after the first copy of the questionnaire was mailed. A second copy of the questionnaire was mailed to nonrespondents approximately 2 to 3 weeks after the first questionnaire, and a third copy was mailed to those who had not responded about 2 to 3 weeks after the second mailing.

1 Dillman, D. A. (1978). Mail and telephone surveys. John Wiley and Sons, New York. 


\section{User Profiles}

Some of the results of the study are presented in this section. Data collection results are discussed first, followed by a general description of the Corps day-use visitors and their attitudes toward fees.

\section{Data Collection Results}

Data collection results for the day-use survey are reported in Table 2. A total sample of 2,665 names and addresses were collected at the projects, excluding the names and addresses of six people who wrote or telephoned to indicate that someone else must have used their name because they had not visited the projects during the sampling period.

\begin{tabular}{|c|c|c|c|c|c|}
\hline Project & $\begin{array}{l}\text { Names } \\
\text { Collected }\end{array}$ & $\begin{array}{l}\text { Undeliverable } \\
\text { Surveys }\end{array}$ & $\begin{array}{l}\text { Adjusted } \\
\text { Sample Size }\end{array}$ & $\begin{array}{l}\text { Number of } \\
\text { Surveys } \\
\text { Returned }\end{array}$ & $\begin{array}{l}\text { Response } \\
\text { Rate as \% } \\
\text { of Adjusted } \\
\text { Sample Size }\end{array}$ \\
\hline Burnsville & 394 & 7 & 387 & 230 & 59.4 \\
\hline Strom Thurmond & 462 & 11 & 451 & 241 & 53.4 \\
\hline J. Percy Priest & 461 & 45 & 416 & 210 & 50.5 \\
\hline Truman & 428 & 22 & 406 & 232 & 57.1 \\
\hline Canyon & 461 & 31 & 430 & 236 & 54.9 \\
\hline Mendocino & 459 & 27 & 432 & 230 & 53.2 \\
\hline Unknown & & & & 26 & \\
\hline Total & 2,665 & 143 & 2,522 & 1,405 & 55.7 \\
\hline
\end{tabular}


The target sample size of $\mathbf{4 6 2}$ for each project was not achieved at Burnsville or Truman. In the former case, an illness in the family forced the survey couple to leave prior to the completion of the sample collection process. Although another couple replaced them, it was not possible to collect all the names and addresses desired. At Truman, high-water levels during the last week of the sample collection process forced the closing of the day-use areas where names and addresses were being collected.

A total of 143 questionnaires were undeliverable because of insufficient or incorrect addresses. The number of undeliverable questionnaires was higher than anticipated, especially at J. Percy Priest, where almost 10 percent of the questionnaires could not be delivered. Subtracting the undeliverable questionnaires from the total names and addresses collected yields an adjusted sample size of 2,522 for the study. The adjusted sample size ranges from a low of 406 at Truman to 451 at Strom Thurmond.

A total of 1,405 surveys were returned by October 1,1993 . The number of returned questionnaires varied from 210 at J. Percy Priest to 241 at Strom Thurmond. Twenty-six completed questionnaires were returned with the identification number crossed out; hence, the project from which they were returned is unknown.

The overall response rate to the survey was 55.7 percent of the adjusted sample size and ranged from 50.5 percent at J. Percy Priest to 59.4 percent at Burnsville. The overall and individual project response rates are about 10 percent lower than expected. Respondents also failed to answer individual questions at a higher rate than in the companion camper survey.

Several factors may have contributed to this response rate. They include the length of the questionnaire, uncertain mail delivery partly because of extensive flooding in the Midwest, and low levels of commitment to the survey among day-use visitors.

\section{Sociodemographic and Trip Characteristics of Day Users}

A summary of the sociodemographic characteristics of Corps day-use respondents is provided in Table 3 . The average age was 40 years, and males accounted for 61.5 percent of all respondents. Average household size was three people. Respondents reported an average of 13.3 years of education and an average income of $\$ 36,300$. The number of respondents who identified themselves as members of minority groups was 11.6 percent. Note that a statistically significant variation exists across the six lakes for all the sociodemographic variables presented in Table 3. In particular, there is about a $\$ 15,000$ difference between the highest average income (J. Percy Priest) and the lowest (Burnsville). Income levels of respondents at Strom Thurmond, J. Percy Priest, Truman, and Canyon are 
quite similar, but are significantly higher than the levels reported for Burnsville and Mendocino.

Table 3

Sociodemographic Characteristics of Corps Day-Use Visitors, by Project

\begin{tabular}{|l|l|l|l|l|l|l|l|}
\hline Characteristic & Burnsville & $\begin{array}{l}\text { Strom } \\
\text { Thurmond }\end{array}$ & $\begin{array}{l}\text { J. Percy } \\
\text { Priest }\end{array}$ & Truman & Canyon & Mendocino & All Lakes \\
\hline Average age* & 39.5 & 35.5 & 38.2 & 44.7 & 42.1 & 41.5 & 40.2 \\
\hline Sex, \% male* & 60.0 & 64.5 & 59.8 & 69.4 & 56.3 & 60.5 & 61.5 \\
\hline $\begin{array}{l}\text { Average } \\
\text { household size* }\end{array}$ & 3.1 & 3.3 & 3.3 & 2.8 & 2.9 & 3.0 & 3.1 \\
\hline $\begin{array}{l}\text { Average } \\
\text { education, years* }\end{array}$ & 12.5 & 13.6 & 13.5 & 13.3 & 13.9 & 13.2 & 13.3 \\
\hline $\begin{array}{l}\text { Average income,* } \\
\text { in thousands }\end{array}$ & 25.6 & 39.8 & 40.1 & 38.4 & 40.3 & 33.3 & 36.3 \\
\hline $\begin{array}{l}\text { Race, \% } \\
\text { non-Caucasian* }\end{array}$ & 11.2 & 13.2 & 8.2 & 4.0 & 18.9 & 13.4 & 11.6 \\
\hline
\end{tabular}

Note: * Denotes a statistically significant difference in Project means at the 10-percent level, two-tail test.

Trip characteristics of respondents are reported in Table 4. Average party size was 3.2 overall, and the average number of hours spent at the site was 5. Average one-way travel distance varied from only 12 miles $^{1}$ at J. Percy Priest to 45 miles at Canyon. As expected, travel costs at the six lakes were highly correlated with the one-way distance traveled. Note that respondents took an average of 21 trips per year to the day-use area at which they were contacted. Respondents at Mendocino reported the highest number of annual trips.

Respondents were also asked to rank the overall quality of the day-use area they visited and to express their overall preference for the area visited. Quality was rated using a 5-point scale, with " 1 " representing "poor" and "5" representing "excellent." While all six lakes rated quite highly in terms of quality, some differences were observed. Strom Thurmond received the highest rating (4.0 on the 5-point scale) and Canyon received the lowest (3.2), probably because of the damages caused by flooding during recent years. All other lakes have a quality rating in the range of 3.5 to 3.9 on the 5-point scale.

1 To convert miles (U.S. statute) to kilometers, multiply number of miles by 1.609347 . 


\section{Table 4}

\section{Trip Characteristics of Corps Day-Use Visitors, by Project}

\begin{tabular}{|l|l|l|l|l|l|l|l|}
\hline $\begin{array}{l}\text { Trip } \\
\text { Characteristic }\end{array}$ & Burnsville & $\begin{array}{l}\text { Strom } \\
\text { Thurmond }\end{array}$ & $\begin{array}{l}\text { J. Percy } \\
\text { Priest }\end{array}$ & Truman & Canyon & Mendocino & All Lakes \\
\hline $\begin{array}{l}\text { Average no. of } \\
\text { people in party* }\end{array}$ & 3.2 & 3.6 & 3.0 & 3.0 & 3.4 & 2.9 & 3.2 \\
\hline $\begin{array}{l}\text { Average no. of } \\
\text { hours spent at } \\
\text { rec. area* }\end{array}$ & 4.8 & 6.7 & 4.6 & 4.5 & 5.2 & 4.2 & 5.0 \\
\hline $\begin{array}{l}\text { Average } \\
\text { one-way travel } \\
\text { distance* }\end{array}$ & 33.1 & 24.8 & 12.0 & 44.5 & 45.0 & 20.1 & 30.2 \\
\hline $\begin{array}{l}\text { Average total trip } \\
\text { expenses* }\end{array}$ & 22.45 & 24.32 & 16.50 & 38.10 & 46.80 & 25.60 & 36.40 \\
\hline $\begin{array}{l}\text { Average annual } \\
\text { trips }\end{array}$ & 20.4 & 14.6 & 24.6 & 17.5 & 8.7 & 40.7 & 21.0 \\
\hline $\begin{array}{l}\text { Average quality } \\
\text { rating for area } \\
\text { visited }\end{array}$ & 3.8 & 4.0 & 3.8 & 3.9 & 3.2 & 3.5 & 3.7 \\
\hline $\begin{array}{l}\text { Average } \\
\text { preference rating } \\
\text { for area visited }\end{array}$ & 2.4 & 2.2 & 2.2 & 2.3 & 2.5 & 2.3 & 2.3 \\
\hline \begin{tabular}{l} 
Ant* \\
\hline
\end{tabular} & & & & & & & \\
\hline
\end{tabular}

Note: * Denotes a statistically significant difference in Project means at the 10-percent level, two-tail test.

${ }^{1}$ The following numerical scale was used to measure quality: 1 = excellent; 2 = very good; $3=$ good; 4 = fair; and $5=$ poor.

${ }^{2}$ The following numerical scale was used to measure preferences: $1=1$ would not go elsewhere in this region; $2=1$ would go elsewhere, but I prefer this day-use area; 3 = It makes no difference to me whether I use this day-use area or another area; 4 = I would come here again, but I would prefer to go elsewhere; and 5 = I would not come here again.

Users' preferences for the day-use area they visited were also measured using a 5-point Likert-type scale. In this case, a value of 1 was assigned to a very high preference, and a value of 5 was used to denote a very low preference for the area visited. Again, users expressed a high preference of the areas visited, with Strom Thurmond and J. Percy Priest each receiving a rating of 2.2 on the five-point scale. Canyon Lake received the lowest rating of 2.5 , again probably because of the damages that occurred during recent flooding. All trip-related characteristics reported in Table 4 are also statistically different across the six projects at the 10 -percent level. 


\section{Revenue Projections and Fee Impacts on Population Subgroups}

Two objectives of the study were to estimate the revenue that could be collected at alternative fee levels if a fee system was implemented and to determine the impact that fees would have on selected subgroups of visitors. The procedures used to address these objectives and the results obtained are discussed below.

The fee portion of the study was designed on the assumption that both a daily per vehicle fee and an annual pass fee would be offered to visitors if a fee system was implemented by the Corps. Consequently, the introduction of a fee system would present potential visitors with three choices: pay the daily per vehicle fee; purchase the annual pass; or pay neither fee and stop visiting the site. Respondents were presented with these options in the question:

There is legislation before Congress that would establish day-use fees at Corps of Engineer day-use areas, like the one where your vehicle was stopped. The Corps is interested in your views on recreation day-use fees. Suppose a recreation dayuse fee was charged at the recreation day-use area where your vehicle was stopped, and at other similar Corps-operated day-use areas nationwide. If the fee was $\$ \_$per vehicle per day, or $\$ \_$per vehicle for an annual pass that would allow you to use all the day-use areas located on this lake for one year, which option would you personally choose? (please circle one number)
1. I would pay the per-vehicle per-day fee
2. I would purchase the annual pass
3. Neither-I would not visit Corps day-use areas anymore

Fee levels ranging from $\$ 1$ to $\$ 5$ for the daily fee and from $\$ 10$ to $\$ 100$ for the annual pass were written in the appropriate spaces prior to mailing the surveys. The wording of the question notes the possibility of a fee system in the future and that the fee system would be implemented nationwide at selected Corps day-use areas, and not just the area they visited. 
It also presented respondents with the choices they would face and allowed them to indicate which of the three options they would exercise.

\section{Estimation of Fee Revenue}

Responses to the three-choice fee question were also used to estimate the amount of revenue that could be collected at the six projects if a fee system was implemented. A polychotomous choice selectivity model was used to obtain the information needed to estimate revenues at each lake. This model involved two steps. In the first, a multinomial logit model was estimated to assess the impact of the independent variables on respondents' choices. It was then used to assign each respondent to the fee category with the highest probability for that person at different fee levels. Thus, the multinomial logit model essentially partitioned respondents into three categories: those predicted to pay the daily fee; those predicted to pay the annual pass fee; and those predicted to pay neither fee. The predictions were made on the basis of the independent variables in the model. The independent variables included in the multinomial logit model are shown in Table 5.

\section{Table 5}

Independent Variables Included in the Multinomial Logit Model

\begin{tabular}{|c|c|}
\hline Variable & Description \\
\hline $\begin{array}{l}\text { DAYFEE } \\
\text { ANNFEE } \\
\text { INCOME } \\
\text { DISTANCE } \\
\text { VISITS }\end{array}$ & $\begin{array}{l}\text { Daily fee, with a range of } \$ 1 \text { to } \$ 5 \text {. } \\
\text { Annual pass fee, with a range of } \$ 10 \text { to } \$ 100 \text {. } \\
\text { Total } 1992 \text { gross household income ( } \$ 1000) \text {. } \\
\text { One-way travel distance from home to day-use area. } \\
\text { Number of visits made to day-use area in last year (without fees). }\end{array}$ \\
\hline $\begin{array}{l}\text { Binary (dummy) } \\
\text { variables for each } \\
\text { lake: } \\
\text { LAKE1 } \\
\text { LAKE2 } \\
\text { LAKE3 } \\
\text { LAKE4 } \\
\text { LAKE5 } \\
\text { LAKE6 }\end{array}$ & $\begin{array}{l}=1 \text { if Bumsville } ;=0 \text { otherwise. } \\
=1 \text { if Strom Thurmond; }=0 \text { otherwise. } \\
=1 \text { if J.Percy Priest } ;=0 \text { otherwise. } \\
=1 \text { if Truman }=0 \text { otherwise. } \\
=1 \text { if Canyon }=0 \text { otherwise. } \\
\text { Mendocino Lake, the omitted category. }\end{array}$ \\
\hline QLTY & $=1$ if respondent rated quality of site as very good or excellent; = 0 otherwise. \\
\hline PREFER & $=1$ if respondent indicated a strong preference for the site; $=0$ otherwise. \\
\hline PAIDFEE & $=1$ if respondent had paid a day-use fee at a lake during last year; = 0 otherwise. \\
\hline BOAT & $=1$ if a boat was used during visit when respondent's vehicle was stopped; $=0$ otherwise. \\
\hline RACE & $=1$ if respondent was not Caucasian; $=0$ otherwise. \\
\hline
\end{tabular}

The dependent variable in the multinomial logit model was limited to three values corresponding to the three choices available to respondents: "zero" if the respondent indicated they would not pay either fee; "one" if 
the respondent chose the daily fee option; and "two" if the respondent chose the annual pass. The independent variables are used to "explain" the observed differences in the responses to the fee question.

This initial step in the polychotomous choice selectivity model provided an estimate of the number of people in the sample who would choose the annual pass option at alternative daily and annual fee levels. Revenue projections from the sale of annual passes were calculated by multiplying the number of people in the sample who would purchase the annual pass at alternative prices. The revenue collected from the people in the sample was then expanded to the population of day-users using appropriate expansion factors.

In the second step of the polychotomous choice selectivity model, data from the respondents who were predicted to choose the daily-fee option were used to estimate a demand equation describing the number of visits that would be made to the site at alternative daily fee levels. Ordinary least squares techniques were used to estimate the demand equation. The dependent variable was the number of visits respondents would have made during the last 12 months if the fees specified in the fee question had been charged. ${ }^{1}$

The independent variables included in the demand equation are very similar to those included in the multinomial logit model and are reported in Table 6. The annual pass fee was not included in the demand model. Its effect had already been included when respondents were assigned to the daily fee category. However, a new variable, an interaction term between income and the daily fee (FEEINCOME), was included in the demand model. This term was used to determine whether users with different income levels would respond to changes in the daily fee in similar or different ways. For example, a positive significant coefficient associated with the interaction term would indicate that, at higher fee levels, low-income users would reduce their visitations more than high-income users. Consequently, this variable provided an opportunity to determine whether fees discriminate against lower income people currently using Corps day-use areas.

The demand model described above empirically specified the relationship between the daily fee and the number of visits that would be made by respondents predicted to choose the daily-fee option. This price-quantity relationship was used to estimate the revenue that would be collected through the daily fee from the sample respondents at different fee levels. Revenues were then projected to the population using appropriate expansion factors (Appendix B, Table B5). Finally, revenues from the daily fee and annual pass fee were summed to estimate the total revenue that could be collected.

1 Respondents who selected the daily fee option were asked how many trips they would have made in the last 12 months if the fees specified in the initial fee question had been charged. Their responses are the dependent variable in the equation. 


\section{Table 6 Independent Variables Included in the Demand Model}

\begin{tabular}{|c|c|}
\hline Variable & Description \\
\hline $\begin{array}{l}\text { DAYFEE } \\
\text { INCOME } \\
\text { FEEINC } \\
\text { DISTANCE } \\
\text { VISITS }\end{array}$ & $\begin{array}{l}\text { Daily fee, with a range of } \$ 1 \text { to } \$ 5 \text {. } \\
\text { Total } 1992 \text { gross household income }(\$ 1000) \text {. } \\
\text { Interaction term: daily fee * income. } \\
\text { One-way travel distance from home to day-use area. } \\
\text { Number of visits made to day-use area in last year (without fees). }\end{array}$ \\
\hline $\begin{array}{l}\text { Binary (dummy) } \\
\text { variables for each } \\
\text { lake: } \\
\text { LAKE1 } \\
\text { LAKE2 } \\
\text { LAKE3 } \\
\text { LAKE4 } \\
\text { LAKE5 } \\
\text { LAKE6 }\end{array}$ & $\begin{array}{l}=1 \text { if Burnsville; }=0 \text { otherwise. } \\
=1 \text { if Strom Thurmond; }=0 \text { otherwise. } \\
=1 \text { if J.Percy Priest; }=0 \text { otherwise. } \\
=1 \text { if Truman; }=0 \text { otherwise. } \\
=1 \text { if Canyon; }=0 \text { otherwise. } \\
\text { Mendocino Lake, the omitted category. }\end{array}$ \\
\hline QLTY & $=1$ if respondent rated quality of site as very good or excellent; $=0$ otherwise. \\
\hline PREFER & $=1$ if respondent indicated a strong preference for the site; $=0$ otherwise. \\
\hline PAIDFEE & $=1$ if respondent had paid a day-use fee at a lake during last year; $=0$ otherwise. \\
\hline BOAT & $=1$ if a boat was used during visit when respondent's vehicle was stopped; = 0 otherwise. \\
\hline RACE & $=1$ if respondent was not Caucasian; $=0$ otherwise. \\
\hline
\end{tabular}

The estimated multinomial logit model is presented in Table 7. An intuitive description of the results is presented here. Two equations were estimated: one for the daily fee option and the other for the annual pass option. The "neither fee" option was the base category; hence, the coefficients in the daily fee equation indicated how the independent variables affect the probability of choosing the daily fee over the "neither fee" option. Likewise, the coefficients in the annual pass equation described how the independent variables affect the probability of choosing the annual pass over the "neither fee" option. The daily fee multinomial logit equation is discussed first.

First, three variables in the equation were statistically insignificant at the 10-percent level: INCOME, RACE, and BOAT. That is, none of these variables had a significant effect on the probability that respondents would choose the daily fee over the "neither fee" option. These results indicate that the daily fee did not discriminate against users based on their income, race, or boat use while at the day-use areas.

All other variables in the daily fee equation were significant at the 10-percent level. The coefficient on DAYFEE was negative, indicating that the probability of a respondent choosing the daily fee option over the "neither fee" option decreased as the daily fee increased. The ANNFEE coefficient was positive, suggesting that the probability of choosing the daily fee option increased as the annual fee increased. The coefficient on the DISTANCE variable was positive, so the probability of choosing the 
Table 7

Maximum Likelihood Estimates for the Multinominal Logit Model

\begin{tabular}{|c|c|c|c|c|c|c|}
\hline \multirow[b]{2}{*}{ Variable } & \multicolumn{3}{|c|}{ Daily Fee Equation } & \multicolumn{3}{|c|}{ Annual Pass Equation } \\
\hline & Coefficient & Std. Error & t-ratio & Coefficient & Std. Error & t-ratio \\
\hline Constant & 0.321 & 0.417 & 0.77 & -0.319 & 0.438 & -0.73 \\
\hline DAYFEE & $-0.461^{*}$ & 0.0768 & -6.00 & 0.073 & 0.076 & -0.95 \\
\hline ANNFEE & $0.017^{*}$ & 0.0042 & 4.09 & $-0.037^{*}$ & 0.005 & -7.00 \\
\hline INCOME & 0.004 & 0.0034 & 1.22 & $0.007^{\star}$ & 0.004 & 1.98 \\
\hline DISTANCE & $0.008^{*}$ & 0.0032 & 2.51 & -0.005 & 0.004 & -1.38 \\
\hline VISITS & $-0.047^{\star}$ & 0.0072 & -6.55 & 0.001 & 0.002 & 0.55 \\
\hline LAKE1 & $-0.680^{*}$ & 0.284 & -2.40 & -0.246 & 0.314 & -0.78 \\
\hline LAKE2 & -0.052 & 0.279 & -0.19 & $0.518^{*}$ & 0.301 & 1.72 \\
\hline LAKE3 & $-0.498^{*}$ & 0.292 & -1.71 & 0.366 & 0.297 & 1.23 \\
\hline LAKE4 & $-0.586^{\star}$ & 0.292 & -2.01 & 0.175 & 0.328 & 0.53 \\
\hline LAKE5 & 0.486 & 0.295 & 1.65 & $0.897^{*}$ & 0.0333 & 2.69 \\
\hline QLTY & $0.496^{*}$ & 0.170 & 2.92 & 0.371 & 0.185 & 2.01 \\
\hline PREFER & $0.806^{*}$ & 0.169 & 4.77 & 1.039 & 0.196 & 5.32 \\
\hline PAIDFEE & $0.782^{*}$ & 0.213 & 3.67 & $1.142^{*}$ & 0.222 & 5.15 \\
\hline BOAT & -0.043 & 0.187 & -0.23 & 0.022 & 0.197 & 0.11 \\
\hline RACE & -0.059 & 0.251 & -0.23 & -0.243 & 0.265 & -0.92 \\
\hline
\end{tabular}

daily fee option increased as the distance traveled to reach the site increased. The negative coefficient on the VISITS variable indicates that the probability of choosing the daily fee over "neither fee" decreased as the number of visits made to the day-use area in the last year increased. The set of LAKE dummy variables suggests that significant differences existed across the six lakes with respect to the probability of choosing the daily fee over the "neither fee" choice. The QLTY and PREFER coefficients were both positive indicating that higher quality and preference ratings increase the probability of choosing the daily fee option over the "neither fee" option. Finally, the positive coefficient on the PAIDFEE variable suggests that the probability of choosing the daily fee over "neither fee" increased if the respondent had paid a day-use fee at a lake in the last year. The signs on all the significant variables were consistent with expectations.

For the annual pass equation, five variables are statistically insignificant at the 90-percent level: DAYFEE, DISTANCE, VISITS, RACE, and BOAT. Consequently, these variables did not significantly influence 
users' probability of choosing the annual pass option over the "neither fee" option. It is important to note that RACE is not significant in either of the multinomial equations estimated. Hence, this analysis also suggests that minority users will not be more severely affected by a fee system than nonminority users.

The coefficients associated with the following variables in the annual pass equation were positive and statistically significant at the 10-percent level: INCOME, QLTY, PREFER, and PAIDFEE. Consequently, increases in the value of these variables increase the probability that visitors will choose the annual pass option over the "neither fee" option. It is important to note that, contrary to the daily fee equation discussed above, INCOME was statistically significant in the annual pass equation. This result suggests that lower income users are more likely to select the "neither fee" option over the annual pass than are current users with higher incomes. Therefore, the probability that users with lower incomes will be excluded by a fee system is higher than for high-income users.

As expected, the coefficient on ANNFEE is statistically significant and negative, which indicates that the probability of choosing the annual pass instead of the "neither fee" option decreased as the magnitude of the annual pass fee increases. The set of dummy variables for each LAKE is also statistically significant. That is, significant differences exist across the six lakes with respect to the probability that users will select the annual pass fee over the "neither fee" option.

Overall, the multinomial logit model seems to perform well in that the results conform closely with the results obtained by comparing users who chose to pay one of the two fees with those that chose the "neither fee" option. The coefficients generally possess the hypothesized signs, and most are statistically significant. The model correctly categorized 58 percent of the respondents, which is considered quite acceptable for a three-choice model.

The demand equation estimated for the respondents who were predicted to belong to the daily fee category is presented in Table 8. Again, only an intuitive interpretation of the results is presented here.

Six of the coefficients, excluding the constant term, are statistically significant at the 10-percent level: DAYFEE, INCOME, FEEINCOME, DISTANCE, VISITS, and BOAT. ${ }^{1}$ The negative sign on DAYFEE indicates a negative relationship between the number of trips taken and the magnitude of the daily fee. That is, the demand curve had a negative

1 The coefficient "LAMBDA" in Table 8 has no meaning in terms of the results or their interpretation. One of the primary reasons the polychotomous choice selectivity model was chosen for this study is that it incorporates a "correction procedure" whereby the demand equation estimated in the second step is adjusted for the results of the multinomial logit model estimated in the first step. This adjustment is required because of potential sample selection bias. LAMBDA is associated with the correction procedure. 


\begin{tabular}{|l|l|l|l|}
\hline \multicolumn{4}{|l|}{$\begin{array}{l}\text { Table } 8 \\
\text { Ordinary Least Squares Estimates for the Demand Equation }\end{array}$} \\
\hline \hline Variable & Coefficient & Standard Error & t-ratio \\
\hline LAMBDA & $-2.40^{*}$ & 1.358 & -1.77 \\
\hline Constant & $10.50^{*}$ & 2.103 & 4.99 \\
\hline DAYFEE & -1.31 & 0.428 & -3.05 \\
\hline INCOME & $-0.076^{*}$ & 0.032 & -2.38 \\
\hline FEEINCOME & $0.0181^{*}$ & 0.009 & 2.00 \\
\hline DISTANCE & $-0.034^{*}$ & 0.013 & -2.63 \\
\hline VISITS & $0.331^{*}$ & 0.035 & 9.45 \\
\hline LAKE1 & 1.09 & 1.219 & 0.90 \\
\hline LAKE2 & 1.09 & 1.084 & 1.00 \\
\hline LAKE3 & 0.55 & 1.305 & 0.42 \\
\hline LAKE4 & 1.58 & 1.180 & 1.34 \\
\hline LAKE5 & 1.48 & 1.039 & 1.43 \\
\hline BOAT & $1.88^{*}$ & 0.705 & 2.67 \\
\hline RACE & -0.912 & 0.961 & -0.95 \\
\hline Note: * Statistically significant at 10-percent level, two-tail test. \\
\hline
\end{tabular}

slope, as is the case for almost all demand curves. The coefficient on income was also negative, signifying that higher income users take fewer trips, at a given fee level, than their lower income counterparts. Likewise, the negative coefficient on the DISTANCE variable indicates that people who live farther from the site make fewer trips than those who live near the site. The positive coefficient on the VISITS variable suggests that visitors who made frequent trips to the day-use areas during the last year will continue to make more trips with a fee system than those users who visited the sites less frequently. Finally, the positive coefficient on the BOAT variable indicates that current visitors who used a boat on the visit and were contacted would visit the areas more frequently after the fee system was implemented than visitors who did not use a boat on that trip.

The interaction term FEEINCOME had a positive coefficient. As noted above, this indicates that the slope of the demand curve for lowincome users was less than the slope of the demand curve for higher income users. Consequently, low-income users would reduce their use of the Corps day-use areas more at higher fee levels than would users with higher incomes. That is, low-income users were more sensitive to the magnitude of the daily fee charged. Hence, this result is consistent with the results of the multinomial logit equation. 
Finally, because the coefficient on the RACE variable was insignificant, there is no evidence to suggest that the daily fee level will cause minority groups to respond to the daily fee differently from nonminorities. This result is consistent with earlier findings.

As noted above, the multinomial logit and demand equations, along with expansion factors, are used to estimate the revenue that the Corps could collect at alternative daily and annual fee levels. Before presenting the revenue projections, however, several assumptions on which they are based should be noted.

First, Corps personnel at the projects provided a list of the day-use areas where fees would be charged if a day-use fee system was implemented. They also provided estimates of the annual vehicle count for those dayuse areas. Hence, the revenue projections were based on the assumption that fees would be charged at those day-use areas identified in Table 9.

\section{Table 9 \\ Day-Use Areas Identified as Fees Areas by Corps Personnel, by Project}

\begin{tabular}{|c|c|}
\hline Project & Day-Use Areas Where Fees Would Be Charged \\
\hline Burnsville & Riffle Run and Bulltown. \\
\hline Strom Thurmond & West Dam, Lake Springs, and Amity. \\
\hline J. Percy Priest & Elm Hill, Cook, Seven Points, and Anderson Road. \\
\hline Truman & $\begin{array}{l}\text { Berry Bend, Bledsoe Ferry, Crowe's Crossing, Fairfield, Long Shoal, Osage } \\
\text { Bluff, Sac River, Shawnee Bend, Sparrowfoot, Talley Bend, Thibaut Point, } \\
\text { and Windsor Crossing. }\end{array}$ \\
\hline Canyon & Jacobs Creek, Canyon, Potters Creek, Cranes Mill, and Comal. \\
\hline Mendocino & $\begin{array}{l}\text { Che-Ka-Ka (including Joe Riley and Overlook), Pomo (including Cultural } \\
\text { Center), Ky-En (including Oak Grove and Marina), and Bu Shay (including } \\
\text { Mesa and Inlet). }\end{array}$ \\
\hline
\end{tabular}

Second, recall that samples were collected at only two day-use areas at each project. Because fees will be collected at additional sites at most projects, the revenue projections implicitly assume that users at the other dayuse areas identified as fee areas are similar to those who participated in the study in all important aspects (such as attitudes toward fees, preferences, trip characteristics, and responses to fees).

Also, recall that visitors were surveyed during a 4-week period in June and early July of 1993. However, the revenue projections were based on annual vehicle counts provided by Corps personnel for the entire year of 1992. Hence, the revenue projections implicitly assume that the visitors who use the areas during the other 11 months of the year are similar to those who were selected for the sample in June and July. 
Furthermore, because the revenue analysis was based on annual vehicle counts, it is assumed that fees will be collected during the entire year. If the Corps only collects fees during the summer or some other fraction of the year, different expansion factors would be required to estimate revenues. These expansion factors could not be determined from the survey data because of the way specific questions were worded in the questionnaire.

Revenue projections for each of the six projects are presented in Tables 10-15. ${ }^{1}$ Each table is in matrix form, with the rows representing alternative levels of the annual pass fee and the columns representing alternative levels of the daily fee. Daily fee levels range from $\$ 1$ to $\$ 5$, in one-dollar increments, and the annual pass fee ranges from $\$ 10$ to $\$ 50$ in ten-dollar increments. Each cell in the matrix represents the projected revenue associated with the annual pass fee and daily fee indicated for the intersecting row and column. For example, using projections for Burnsville (Table 10), a daily fee of $\$ 3$ and an annual pass fee of $\$ 20$ yield an estimate of $\$ 20,889$ in total revenue. Other total revenue estimates in the matrix cells are interpreted in the same manner.

\begin{tabular}{|c|c|c|c|c|c|}
\hline \multirow[b]{2}{*}{ Annual Fee } & \multicolumn{5}{|c|}{ Daily Fee } \\
\hline & $\$ 1$ & $\$ 2$ & $\$ 3$ & $\$ 4$ & $\$ 5$ \\
\hline$\$ 10$ & 30,883 & 29,566 & 24,810 & 18,961 & 15,747 \\
\hline$\$ 20$ & 34,258 & 32,715 & 20,889 & 13,369 & 14,462 \\
\hline$\$ 30$ & 34,676 & 40,428 & 27,284 & 18,125 & 16,872 \\
\hline$\$ 40$ & 37,664 & 47,627 & 34,965 & 19,154 & 12,694 \\
\hline$\$ 50$ & 37,150 & 50,648 & 39,528 & 20,889 & 8,677 \\
\hline
\end{tabular}

\section{Table 11 \\ Projected Revenue at Alternative Fee Levels, Strom Thurmond Project}

\begin{tabular}{||l|l|l|l|l|l|}
\hline \multirow{2}{*}{ Annual Fee } & \multicolumn{5}{|c|}{ Daily Fee } \\
\cline { 2 - 6 } & $\$ 1$ & $\$ 2$ & $\$ 3$ & $\$ 4$ & $\$ 5$ \\
\hline$\$ 10$ & 98,941 & 109,974 & 106,237 & 105,821 & 104,991 \\
\hline$\$ 20$ & 123,320 & 174,748 & 193,789 & 203,576 & 198,119 \\
\hline$\$ 30$ & 122,549 & 190,223 & 223,328 & 226,828 & 210,872 \\
\hline$\$ 40$ & 112,999 & 189,993 & 221,964 & 182,934 & 135,243 \\
\hline$\$ 50$ & 114,007 & 194,678 & 231,573 & 206,067 & 148,292 \\
\hline
\end{tabular}

1 The expansion factors used to project revenues for the six projects are reported in Appendix B, Table B5. 


\begin{tabular}{|c|c|c|c|c|c|}
\hline \multirow[b]{2}{*}{ Annual Fee } & \multicolumn{5}{|c|}{ Daily Fee } \\
\hline & $\$ 1$ & $\$ 2$ & $\$ 3$ & $\$ 4$ & $\$ 5$ \\
\hline$\$ 10$ & 151,212 & 147,437 & 145,439 & 114,328 & 142,108 \\
\hline$\$ 20$ & 221,822 & 256,682 & 257,904 & 248,689 & 228,705 \\
\hline$\$ 30$ & 224,708 & 240,473 & 248,800 & 196,509 & 136,557 \\
\hline$\$ 40$ & 163,757 & 162,980 & 112,243 & 61,728 & 48,850 \\
\hline$\$ 50$ & 137,778 & 152,766 & 113,797 & 67,945 & 22,202 \\
\hline
\end{tabular}

\begin{tabular}{|c|c|c|c|c|c|}
\hline \multirow[b]{2}{*}{ Annual Fee } & \multicolumn{5}{|c|}{ Daily Fee } \\
\hline & $\$ 1$ & $\$ 2$ & $\$ 3$ & $\$ 4$ & $\$ 5$ \\
\hline$\$ 10$ & 224,960 & 248,130 & 227,909 & 223,275 & 208,530 \\
\hline$\$ 20$ & 289,204 & 343,759 & 313,217 & 255,292 & 210,637 \\
\hline$\$ 30$ & 257,609 & 310,479 & 247,709 & 140,705 & 78,989 \\
\hline$\$ 40$ & 244,128 & 337,019 & 250,026 & 160,927 & 78,989 \\
\hline$\$ 50$ & 269,194 & 397,682 & 320,168 & 206,003 & 91,627 \\
\hline
\end{tabular}

\begin{tabular}{|c|c|c|c|c|c|}
\hline \multirow[b]{2}{*}{ Annual Fee } & \multicolumn{5}{|c|}{ Daily Fee } \\
\hline & $\$ 1$ & $\$ 2$ & $\$ 3$ & $\$ 4$ & $\$ 5$ \\
\hline$\$ 10$ & 362,068 & 465,042 & 453,416 & 414,662 & 417,982 \\
\hline$\$ 20$ & 413,002 & 641,094 & 701,992 & 684,276 & 701,715 \\
\hline$\$ 30$ & 446,772 & 712,511 & 842,058 & 848,702 & 840,120 \\
\hline$\$ 40$ & 470,578 & 766,212 & 888,562 & 864,757 & 740,469 \\
\hline$\$ 50$ & 454,800 & 770,641 & 958,042 & 960,533 & 798,599 \\
\hline
\end{tabular}

Table 15

Projected Revenue at Alternative Fee Levels, Mendocino Project

\begin{tabular}{|l|l|l|l|l|l|}
\hline \multirow{2}{*}{ Annual Fee } & \multicolumn{5}{|c|}{ Daily Fee } \\
\cline { 2 - 6 } & $\$ 1$ & $\$ 2$ & $\$ 3$ & $\$ 4$ & $\$ 5$ \\
\hline$\$ 10$ & 30,646 & 33,197 & 29,867 & 26,644 & 24,979 \\
\hline$\$ 20$ & 42,007 & 45,069 & 44,693 & 32,875 & 25,516 \\
\hline$\$ 30$ & 38,112 & 39,858 & 34,889 & 25,838 & 18,935 \\
\hline$\$ 40$ & 35,480 & 43,672 & 40,449 & 30,834 & 21,621 \\
\hline$\$ 50$ & 37,683 & 48,775 & 41,658 & 34,325 & 20,278 \\
\hline
\end{tabular}


It is important to note that the revenue patterns for the six lakes are the result of a complex array of factors, including the total number of vehicles entering the designated fee areas in 1992, expansion factors, user's attitudes toward fees, and the percent of respondents categorized in the "daily fee," "annual pass," and "neither fee" options by the multinomial logit model for each lake. The rate at which respondents convert to annual passes as the daily fee increases is another important factor, as is the rate at which users convert to the daily fee as the annual pass increases in price. Finally, the rate at which users convert to the "neither fee" option as both the daily fee and annual pass increase in price is important.

The interaction of these factors produced revenue patterns that differ across the six lakes. For example, the annual pass/daily fee combinations that yield the maximum revenue projections for the six projects are listed in the adjacent tabulation.

\begin{tabular}{|l|l|}
\hline Burnsville & $\$ 50 / \$ 2$ \\
\hline Strom Thurmond & $\$ 50 / \$ 3$ \\
\hline J. Percy Priest & $\$ 20 / \$ 3$ \\
\hline Truman & $\$ 50 / \$ 2$ \\
\hline Canyon & $\$ 50 / \$ 4$ \\
\hline Mendocino & $\$ 50 / \$ 2$ \\
\hline
\end{tabular}

However, other annual/daily fee combinations result in almost as much income as the fee combination associated with maximum revenue. For example, the fee combination of $\$ 30 / \$ 3$ results only in a loss of about $\$ 8,000$ when compared with the maximum revenue reported for Strom Thurmond. Using J. Percy Priest data, the fee combination of $\$ 20 / \$ 2$ results only in about a $\$ 1,300$ loss in revenue when compared with the maximum.

Note that, at some of the projects, the loss in revenue associated with setting fees "too high" is greater than the revenue lost by setting fees "too low," at least over the fee ranges included in the tables. As an example, consider J. Percy Priest. Setting fees at the $\$ 50 / \$ 5$ rate results in an estimated revenue of only $\$ 22,200$. In contrast, the lowest fee combination of $\$ 10 / \$ 1$ yields an estimated revenue of over $\$ 150,000$. The same pattern exists for Burnsville, Truman, and Mendocino. Clearly, many of the current users at these projects would opt to not visit the day-use areas at the higher end of the fee ranges. These are the same lakes that expressed the strongest negative attitudes toward fees.

On the other hand, there is a larger risk of lost revenue from "underpricing" than "overpricing" at Strom Thurmond, within the range of fees reported in the tables. The highest fee combination of $\$ 50 / \$ 5$ yields about $\$ 148,000$ in revenue, compared with only $\$ 99,000$ for the lowest fee combination of $\$ 10 / \$ 1$. The same pattern holds for Canyon Lake. Again, these results are consistent in that users at these projects, in relative terms, had the strongest positive attitudes toward day-use fees. A higher proportion of the users at these projects also had paid a fee to use a dayuse area located on a lake or reservoir in the last year.

The projections presented above are considered to be minimum estimates of annual fee revenues. There are several reasons for this belief. First, users' responses to the three-choice fee question are based on their 
"behavioral intentions" rather than actual behavior. Although economists rely on behavioral intentions rather than actual behavior to predict behavior and/or values, respondents may behave differently from the way they indicated in the fee question. Many people who said they would stop using the Corps day-use areas if fees were implemented still expressed favorable quality and preference ratings for the sites. Furthermore, users may have only limited choices in terms of substitute sites. Therefore, some users may reconsider their decision in light of the available alternatives. Other current users who do stop visiting the facilities may, in fact, begin using them again after a period of absence.

Second, the strong negative attitudes toward fees expressed by users seem to be based on philosophical grounds. Consequently, they may have behaved "strategically" by indicating they would not visit the Corps areas in the future if a fee system was implemented, when, in fact, they would continue to use the areas after the fee system was implemented. The fact that the users who were unwilling to pay either fee had an average consumer's surplus per trip that is much greater than the daily fee also suggests that some users may continue to visit the areas. If this is the case, it would result in a downward bias in revenue projections.

Third, this survey only considered current users. There may well be current nonusers who would visit the day-use areas in the future, and thereby partially or completely offset the current users who will be displaced by the fee system. This is especially true at those day-use areas that currently turn people away because of capacity constraints, as is the case at the Lake Springs day-use area at Strom Thurmond.

\section{Fee Impacts on Population Subgroups}

Responses to the fee question were analyzed to determine how the introduction of a fee system would impact different subgroups of current visitors. A comparison was undertaken of users who self-selected the "neither fee" option with users who chose to pay one of the two fees. This comparison was useful in identifying the characteristics of users who may be displaced by the fee system. Such a comparison for selected sociodemographic and trip-related variables is presented in Table 16.

No statistically significant difference (at the 10-percent level) exists in terms of age, household size, and the percent minority group members in each group. These results indicate that the fee system would not discriminate among current users on the basis of these characteristics. The latter finding is particularly important because one of the objectives of the fee study was to determine whether the implementation of a fee system would disadvantage current minority users more than nonminority users. This result is also consistent with the results from the models presented in the previous section. 


\begin{tabular}{|c|c|c|}
\hline \multicolumn{3}{|c|}{$\begin{array}{l}\text { Table } 16 \\
\text { Sociodemographic and Trip Characteristics of Corps Day-Use } \\
\text { Visitors, by Willingness to Pay Day-Use Fee }\end{array}$} \\
\hline Characteristic & Would Pay Fee & Would Not Pay Fee \\
\hline Average age, years & 40.3 & 40.0 \\
\hline Sex, percent male* & 58.9 & 65.3 \\
\hline Average household size, people & 3.1 & 3.0 \\
\hline Average education, years & 13.5 & 13.0 \\
\hline Average income, $\$$ & 38,600 & 32,800 \\
\hline Race, \% non-Caucasian & 12.5 & 10.6 \\
\hline Average party size, ${ }^{*}$ persons & 3.3 & 3.0 \\
\hline Average no. of hours spent at rec. area* & 5.4 & 4.5 \\
\hline Average one-way travel distance, ${ }^{*}$ miles & 32.8 & 26.8 \\
\hline Average total trip expenses*, $\$$ & 29.80 & 25.33 \\
\hline Average preference rating for area visited ${ }^{1 *}$ & 2.1 & 2.4 \\
\hline Average no. of visits to rec. area in last 12 months* & 16.6 & 27.3 \\
\hline $\begin{array}{l}\text { Visited lake area in last } 12 \text { months where day-use fee } \\
\text { was charged, \% yes* }\end{array}$ & 26.8 & 12.2 \\
\hline \multicolumn{3}{|c|}{$\begin{array}{l}\text { Note: * Denotes a statistically significant difference in group means at the } 10 \text {-percent level, two-tail } \\
\text { test. } \\
\text { The following numerical scale was used to measure preferences; } 1=1 \text { would not go elsewhere } \\
\text { in this region; } 2=I \text { would go elsewhere, but I prefer this day-use area; } 3=\text { It makes no difference } \\
\text { to me whether I use this day-use area or another area; } 4=I \text { would come here again, but I would } \\
\text { prefer to go elsewhere; and } 5=I \text { would not come here again. }\end{array}$} \\
\hline
\end{tabular}

On the other hand, the comparison indicates that significant differences do exist for the other variables listed in Table 16. The group that selected the "neither fee" option has a higher percentage of males, a lower level of education, and a lower income level. The latter difference is especially important in that one of the questions to be addressed in the study is whether a fee system would discriminate against low-income users. The results based on self-selected choices by respondents suggest that income is a significant factor in users' decision about whether to pay one of the two fees or to stop visiting the day-use area. This result is also consistent with the model results.

In terms of trip-related variables, the observed difference between the number of trips taken to the day-use site where respondents were initially contacted is important. Those respondents who indicated they would no longer visit the site with a fee system took over 60 percent more trips during the last 12 months than their counterparts who would pay one of the two fees. One would think that this group would opt for the purchase of 
the annual pass. ${ }^{1}$ However, this was not the case. Other factors must explain this group's aversion to a fee system.

Differences in other trip-related variables are more consistent with expectations. Respondents who were unwilling to pay a fee spent less time at the site, reported lower quality and preference ratings for the areas visited, and fewer of them had paid a fee to use a day-use area located on a lake during the last year. The latter variable may partially explain the aversion to fees expressed by the "neither fee" group. Historical experience in paying fees is often a significant factor in explaining people's attitudes toward fees.

It is important to note that over 40 percent of all respondents indicated they would not visit Corps areas if a fee was charged. This clearly reflects a strong negative attitude toward fees at Corps day-use areas. Responses to the fee question also varied significantly across the six projects. At four of the projects (Burnsville, J. Percy Priest, Truman, and Mendocino) between 47 and 52 percent of the respondents indicated they would no longer visit the Corps day-use areas if a fee system was implemented. In contrast, only about 22 and 30 percent of the respondents at Canyon and Strom Thurmond, respectively, indicated they would no longer visit the day-use area if a fee system was implemented. Canyon and Strom Thurmond also had the highest proportion of respondents who had paid a fee to use other lake-oriented day-use areas in the last 12 months (40.4 and 29.8 percent, respectively).

There are a number of reasons why the "neither fee" subgroup of current day users would choose not to pay a fee. For example, they may feel that the fee is unfair or unnecessary, or they may think that they cannot afford to pay the fee because their current income is too low. Alternatively, they may oppose fees on philosophical grounds, or perhaps they do not value the experience enough to pay the fee. To determine whether the latter is the case, a dichotomous choice consumer's surplus model was estimated for the group of users who indicated that they would not pay the fee.

In the questionnaire, respondents were asked to report the expenditures they made while on the trip during the time their vehicle was stopped. Respondents were then asked whether they would have still made the trip if it had cost " $X$ " dollars more than their actual expenses. Respondents answered the question "yes" or "no." In the question, the value of the additional cost (" $X$ ") ranged from $\$ 1$ to $\$ 125$. However, most of the values for additional cost were between $\$ 5$ and $\$ 75$. The responses to

1 In fact, users who chose the "neither fee" option are not statistically different at the 10-percent level from those who chose the annual pass in terms of age, percent male, race, household size, education level, trip party size, one-way travel distance, total trip expenses, and the number of trips taken in the last 12 months. Statistically significant differences, however, exist for income, quality and preference ratings, and the percent of respondents who paid a day-use fee to visit other lake areas in the last 12 months. 
the additional cost question were used to estimate the dichotomous choice consumer's surplus equation.

The estimated equation is presented in Appendix B, Table B4. The average consumer's surplus or value estimated from that equation was $\$ 28.28$ per trip. That is, the average increase in trip expenses that would have to occur before the "neither fee" users would not have made the trip during which they were contacted was $\$ 28.28$. This is clearly much higher than the range of daily fees and represents a midrange of the annual pass fees presented to users in the study. This result provides strong evidence that the respondents did not select the "neither fee" category because the value they placed on the trip is less than the fee. Clearly, the consumer's surplus or value placed on the trip is much higher than the daily fee levels considered. This suggests that issues other than willingness to pay underlie this group's unwillingness to pay fees. As noted above, such unwillingness may be due in part to notions of unfairness or equity. 


\section{Respondent Motivations, Attitudes, and Expectations Toward Fees}

\section{Motivations to Visit Corps Site}

Respondents were asked about their reasons for visiting the day-use recreation area on the day their name was collected. They were offered a series of possible reasons and asked to rank each on a 5-point scale. At least 70 percent of all respondents ranked relaxing ( 87.8 percent), being together with family and friends ( 88.2 percent), spending time in the outof-doors (95.1 percent), and being physically active ( 74.6 percent) as very important or somewhat important motives for visiting Corps sites. Fortythree (43.3) percent reported spending time on a boat as an important motivation, while 46.6 percent indicated that the opportunity to fish was important to them. Fishing and boating were ranked most important by respondents at Truman Lake.

\section{Importance/Performance Analyses}

Importance/performance (IP) analyses offer insights regarding users' preferences and their judgements regarding current service levels. They were used (a) to identify those facilities or services most valued by Corps users and (b) to gather users' evaluations of Corps' efforts in providing these resources. Both types of information are essential to managers hoping to charge fees. Knowledge of valued resources and users' evaluations of these resources may be used when designing promotional messages (focusing on significant resources), when establishing pricing policies, and when allocating scarce resources. Uses for such information are discussed more fully in Chapter 6. 
Results suggest that several services and facility characteristics are valued above the others offered in this survey instrument (Table 17). Large numbers of respondents ranked the following issues as "Very Important": cleanliness of restrooms (60.9 percent), adequate parking (67.7 percent), friendliness of staff (63.4 percent), scenery (60.6 percent), swimming beaches (60.9 percent), security patrols (46.4 percent), and picnic tables near the beach (45.7 percent).

\section{Table 17}

Importance of Service and Facility Characteristics

\begin{tabular}{|c|c|c|c|}
\hline Service or Facility & Very Important & Somewhat Important & Not Important \\
\hline Swimming beach & 60.9 & 20.9 & 11.1 \\
\hline Playgrounds & 28.5 & 30.5 & 30.0 \\
\hline Picnic tables near beach & 45.7 & 32.4 & 14.1 \\
\hline Covered picnic tables & 31.3 & 35.2 & 24.6 \\
\hline Group shelters & 17.7 & 32.2 & 38.2 \\
\hline Cleanliness of restrooms & 82.2 & 10.8 & 1.9 \\
\hline Hot showers & 23.1 & 26.0 & 40.0 \\
\hline Adequate parking & 67.7 & 22.1 & 2.8 \\
\hline Boat ramps & 41.6 & 22.6 & 26.9 \\
\hline Boat docks or moorings & 29.2 & 27.0 & 33.1 \\
\hline Controlled access to area & 19.2 & 29.5 & 40.1 \\
\hline Fish-cleaning station & 12.2 & 25.6 & 52.1 \\
\hline Bicycle path & 11.3 & 30.2 & 46.5 \\
\hline Hiking, walking trails & 26.8 & 38.4 & 25.5 \\
\hline Nature trails & 18.4 & 37.1 & 32.7 \\
\hline Security patrols & 46.4 & 32.2 & 13.0 \\
\hline Scenery & 60.6 & 25.7 & 4.8 \\
\hline Close to home & 40.2 & 38.2 & 14.3 \\
\hline Remote location & 16.7 & 40.6 & 31.2 \\
\hline Friendliness of staff & 63.4 & 23.6 & 5.2 \\
\hline
\end{tabular}

The Corps seems to be offering appropriate levels of service in terms of these valued programs. Large numbers of respondents reported that the Corps was providing "Excellent" or "Very Good" quality on each of the following services or facilities: cleanliness of rest rooms ( 38.0 percent), adequate parking (44.3 percent), friendliness of staff ( 41.9 percent), scenery ( 53.0 percent), swimming beaches ( 38.0 percent), security patrols 
(20.3 percent), and picnic tables near the beach ( 32.3 percent). It is revealing that few respondents listed the quality of any Corps services as poor. The restroom issue seems the most apparent gap between importance and performance ratings. It ranks as one of the most important issues, yet more than 1 in 10 (11.9 percent) rate Corps performance as poor (Table 18).

\section{Table 18 \\ Quality of Services and Facilities}

\begin{tabular}{|l|l|l|l|}
\hline Service or Facility & $\begin{array}{l}\text { Excellent or } \\
\text { Very Good }\end{array}$ & Good or Fair & Poor \\
\hline Swimming beach & 38.0 & 32.8 & 5.6 \\
\hline Playgrounds & 30.6 & 29.9 & 2.2 \\
\hline Picnic tables near beach & 32.3 & 33.0 & 5.0 \\
\hline Covered picnic tabies & 19.3 & 27.5 & 4.9 \\
\hline Group shelters & 17.7 & 25.0 & 3.4 \\
\hline Cleanliness of restrooms & 30.7 & 36.1 & 11.9 \\
\hline Hot showers & 6.3 & 11.9 & 3.7 \\
\hline Adequate parking & 44.3 & 38.4 & 6.2 \\
\hline Boat ramps & 33.5 & 29.0 & 1.0 \\
\hline Boat docks or moorings & 20.5 & 25.2 & 4.3 \\
\hline Controlled access to area & 22.6 & 17.1 & 3.0 \\
\hline Fish-cleaning station & 4.6 & 7.3 & 2.4 \\
\hline Bicycle path & 6.2 & 12.9 & 2.1 \\
\hline Hiking, walking trails & 14.9 & 19.9 & 1.7 \\
\hline Nature trails & 8.5 & 13.7 & 2.4 \\
\hline Security patrols & 20.3 & 30.0 & 1.3 \\
\hline Scenery & 53.0 & 20.6 & \\
\hline Friendliness of staff & 41.9 & & \\
\hline Note: Because of missing values, responses may not add to 100 percent. & \\
\hline & & & \\
\hline
\end{tabular}

It should be noted that mean IP scores were not compared statistically in these analyses. Mean scores often cloud rather than clarify important trends. Such was the case in this study. Initial tests suggested that although patterns varied widely from service to service, mean scores were generally consistent. In other words, means failed to reflect subtleties found within the data. Consequently, this analysis was conducted using general response patterns rather than mean response levels. 
The IP ratings offered by respondents are noteworthy. High importance ratings were given to items that both enhance the leisure experience (swimming beaches, picnic tables, and boat ramps) and those that diminish possible irritation (cleanliness of restrooms, adequate parking, and proximity to home). The dynamics of the relationship between such variables is unclear. It may be that conditions like cleanliness or parking serve a threshold function. In other words, if they are present (and that quality threshold is crossed), the user will then look to other more relevant variables (swimming beach, picnic tables, etc.) to evaluate the quality of his or her leisure experience. If they are absent, however, the desired quality threshold may not have been reached; the leisure experience will be evaluated in a negative fashion regardless of the quality of other services and facilities. It may be that irritation reduction variables do not ensure a satisfying leisure experience, but their absence may ruin the experience.

Respondents clearly value interaction with staff. Such interaction was important to them when evaluating the quality of their experience at Corps sites. This finding has implications for standard operating procedures and for new pricing strategies. Both will be discussed under "Recommendations."

\section{Agreement with Fees}

These day users generally think of themselves as being price sensitive. A considerable majority ( 92.3 percent) reported that price was important to them when choosing recreation areas. Further, many of these respondents are unused to paying fees to enjoy outdoor recreation experiences. Relatively few (20.3 percent) had paid fees to visit day-use areas located on bodies of water during the last 12 months. This pattern was most evident at J. Percy Priest and Truman Lake where fewer than 7 percent had paid such a fee in the past year. Conversely, almost 40 percent (39.4) of the respondents visiting Canyon Lake had paid fees elsewhere during that period.

These conditions seem to have influenced respondents' view of fee policies. They were offered a series of statements regarding the implementation of fees and were asked to report their level of agreement with those statements. All respondents were asked to respond within a traditional 5-point Likert-type scale. There was considerable disagreement with the idea that fees be charged for day-use areas. Half ( 48.5 percent) of the respondents strongly agreed that they should not pay a fee. Less than half (40.7 percent) reported any willingness to pay a "fair" fee when using Corps day-use areas. Negative reaction to fees was most prominent at Burnsville, Truman, and Mendocino. Mean scores were also calculated across the six lakes. They are reported in Table 19. 


\section{Table 19 \\ Level of Agreement with Statements Regarding \\ Prices Across Projects}

Statement:

(1 - Strongly Agree; 5 - Strongly Disagree)

1: I should not pay a fee to visit Corps of Engineers day-use areas.

Burnsville $\quad 1.63$

Strom Thurmond 2.36

$\begin{array}{ll}\text { J.P. Priest } & 1.97\end{array}$

Truman $\quad 1.79$

Canyon $\quad 2.60$

Mendocino $\quad 1.76$

2: I am willing to pay a fair day-use fee when using Corps day-use areas.

Burnsville $\quad 3.63$

Strom Thurmond 2.75

J.P. Priest $\quad 3.40$

\begin{tabular}{ll} 
Truman & 3.407 \\
\hline
\end{tabular}

Canyon $\quad 2.47$

Mendocino $\quad 3.70$

3: I should not pay a day-use fee unless I use special facilities like boat ramp, group shelters, and bathhouse.

\begin{tabular}{|ll} 
Burnsville & 2.20 \\
Strom Thurmond & 2.86 \\
J.P. Priest & 2.38 \\
Truman & 2.52 \\
Canyon & 2.31 \\
Mendocino & 2.28
\end{tabular}

4: I should pay a day-use fee that covers operation and maintenance costs.

Burnsville $\quad 3.30$

Strom Thurmond 2.55

$\begin{array}{ll}\text { J.P.Priest } & 3.12 \\ \text { Truman } & 3.42\end{array}$

Truman $\quad 3.42$

Canyon $\quad 2.33$

Mendocino $\quad 3.33$

5: I support day-use fees if they are used to maintain my favorite day-use area.

Burnsville $\quad 3.02$

Strom Thurmond 2.29

J.P. Priest $\quad 2.80$
Truman

Truman $\quad 3.28$

Canyon $\quad 2.17$

Mendocino $\quad 2.91$

6: I expect to pay higher fees when using modernized day-use areas.

Burnsville $\quad 3.50$

Strom Thurmond 2.96

$\begin{array}{ll}\text { J.P. Priest } & 3.17\end{array}$

Truman $\quad 3.41$

Canyon $\quad 2.62$

Mendocino $\quad 3.38$

7: Elderly visitors should receive discounts when they use Corps day-use areas.

Burnsville $\quad 1.86$

Strom Thurmond 1.75

J.P. Priest $\quad 2.03$

Truman $\quad 2.26$

Canyon $\quad 1.70$

Mendocino $\quad 1.83$ 


\section{Table 19 (Concluded)}

8: Higher day-use fees on weekends and holidays would encourage me to visit more often during the week.

Burnsville $\quad 3.29$

Strom Thurmond 3.37

J.P.Priest $\quad 3.01$
Truman

Truman $\quad 3.47$

Canyon $\quad 3.26$

Mendocino $\quad 3.44$

9: If the Corps charged a day-use fee, I would no longer visit their day-use areas.

Burnsville $\quad 2.25$

Strom Thurmond 3.27

\begin{tabular}{ll} 
J.P. Priest $\quad 2.53$ \\
\hline
\end{tabular}

Truman 2.43

Canyon $\quad 3.41$

Mendocino $\quad 2.35$

Sixty (60.6) percent of the respondents agreed that they should not be charged a fee unless they used special facilities like a boat ramp, group shelter, or bathhouse. This view was most often reported at Burnsville, Canyon Lake, J. Percy Priest, and Mendocino. There was limited support for fees when respondents believed that service would improve as a result. Fifty-two (52.5) percent supported fees if those fees were used to maintain respondents' favorite day-use areas.

In a related question, respondents were asked where they believed funds gathered through fees at day-use areas should be allocated. The vast majority believed that such funds should be allocated to Corps recreation areas. Specifically, most preferred that the funds be returned to the site at which they were collected (62.3 percent), to any Corps day-use area (12.7 percent), or to any Corps recreational area (10.8 percent). Only 2.4 percent believed that the funds should be used to support any Corps program, and 1.2 percent preferred that the funds be returned to the U.S. Treasury.

Respondents were offered a series of statements regarding actual fee levels. Less than half (44.9 percent) agreed that fee levels should even cover operating and maintenance costs. There was general agreement (74.4 percent) that elderly visitors should be offered discounts from stated fee levels. This is perhaps surprising given that only about 1 in 10 respondents were currently eligible for such discounts.

Respondents were also asked about their intentions should fee policies be implemented. One-third (33.4 percent) reported that higher fees on weekends would encourage them to visit Corps sites more often during weekdays. Unfortunately, almost half ( 48.7 percent) report that they would no longer visit Corps day-use areas if fees were charged. 
Expected fee levels were gathered for a variety of water-based and dry land service packages (Table 20). Lakes reporting the highest and lowest mean price levels are reported here. Generally, boaters expected to pay between $\$ 1.00$ and $\$ 2.00$ for access to a boat ramp and parking (Boat Ramp Package I). Expected price levels rose as respondents received additional services for their money. They expected to pay between $\$ 1.41$ and $\$ 2.73$ if the boat ramp was augmented with security lights, a courtesy dock, and a fish-cleaning station (Boat Ramp Package II). Finally, they expected to pay between $\$ 1.41$ and $\$ 3.63$ when a gate house and attendant were added to the service mix (Boat Ramp Package III). Expected price levels were consistently highest among respondents using Canyon Lake.

Finally, in terms of the boating packages, respondents were asked to report their "favorite" of the three packages. There was considerable support for each of them. Thirty-seven (36.9) percent preferred the first package, while thirty-three (33.4) percent and twenty-nine (29.6) percent preferred Packages II and III, respectively.

Price expectations were then gathered for a variety of dry land service packages. The basic package, which offered uncovered picnic tables, parking, a swimming beach (but no lifeguard), restrooms with flush toilets, and a boat ramp (Picnic Package I), generated mean price expectations ranging from $\$ 1.47$ to $\$ 2.27$. When a gate house with attendant was added (Picnic Package II), mean price levels ranged from $\$ 1.74$ to $\$ 3.05$. The third picnic package offered respondents the basic services with covered picnic tables, electricity, and restrooms with hot showers. Expected price levels ranged from $\$ 2.55$ to $\$ 5.01$ for this final package. Again, Canyon Lake visitors reported among the highest price expectations for all three packages.

When asked to report their favorite dry land package, respondents tended to favor either Package I (45.3 percent) or III (41.3 percent). Only 13.4 percent preferred the second package, which highlighted a gate house and attendant.

The material provided in Table 20 suggests several distinct patterns across sites. First, respondents at Canyon Lake consistently reported the highest price expectations for both the boat ramp and picnic packages. This trend is perhaps surprising in light of an earlier finding that these same respondents also offered the lowest quality rating of all the sites under consideration. These respondents were also used to paying fees for similar programs however. Conversely, respondents at Truman Lake consistently reported the lowest price expectations. This was the case even though over 70 (71.4) percent of respondents at Truman rated their site as being excellent or very good. It seems that past experience with paying fees is more influential than project quality in determining price expectation levels. 


\section{Table 20 \\ Mean Expected Prices for Boat and Picnic Packages Across Projects}

\begin{tabular}{|c|c|c|c|c|c|c|}
\hline \multirow[b]{2}{*}{ Project } & \multicolumn{3}{|c|}{ Boat Packages' } & \multicolumn{3}{|c|}{ Picnic Packages $^{2}$} \\
\hline & 1 & \| & III & I & II & III \\
\hline Burnsville & 1.03 & 1.76 & 2.02 & 1.81 & 2.03 & 3.70 \\
\hline $\begin{array}{l}\text { Strom } \\
\text { Thurmond }\end{array}$ & 1.58 & 2.62 & 3.47 & 1.87 & 2.26 & 3.65 \\
\hline $\begin{array}{l}\text { J. Percy } \\
\text { Priest }\end{array}$ & 1.42 & 2.11 & 2.75 & 2.27 & 2.74 & 3.90 \\
\hline Truman & 0.97 & 1.41 & 1.41 & 1.47 & 1.74 & 2.55 \\
\hline Canyon & 1.83 & 2.73 & 3.63 & 2.25 & 3.05 & 5.01 \\
\hline \multicolumn{7}{|c|}{$\begin{array}{l}{ }^{1} \text { Boat Packages Key: } \\
\text { Boat Package I-Boat ramp with ample parking. } \\
\text { Boat Package II-Boat Package I plus security lights, courtesy dock, and fish- } \\
\text { cleaning station. } \\
\text { Boat Package II-Boat Package II plus a gate house with attendant to control access. } \\
2 \text { Picnic Packages Key: } \\
\text { Picnic Package } 1-A n \text { area with uncovered picnic tables, ample parking, swimming beach } \\
\text { (no lifeguard), restrooms with flush toilets, and a boat ramp. } \\
\text { Picnic Package I-Picnic Package I plus controlled access (a gate house with attendant). } \\
\text { Picnic Package III-Picnic Package II plus covered picnic tables with electricity at each site } \\
\text { and restrooms with hot showers. }\end{array}$} \\
\hline
\end{tabular}

Also, it is clear that price expectations rose consistently as services were added to the water and land-based packages. This trend is encouraging. It suggests a direct relationship between service levels and price expectations. This pattern is important for two reasons. First, it suggests that as users are made aware of additional services, then price expectations should rise accordingly. Managers hoping to charge new or elevated fees should, therefore, focus on the considerable number of services and facilities now available. It is unlikely that users are aware of all the services currently being offered at any given project, and communications that promote the many and varied services may raise price expectations accordingly. Second, this finding suggests that respondents expect to pay more for additional service offerings. Managers should promote any improvement in the number or type of services being offered. Knowledge of more and better services may help increase price expectations and reduce resistance to future price increases.

\section{Price Sensitivity}

An attempt was made to cluster respondents in terms of their reported sensitivity toward fees at Corps projects. In this context, sensitivity refers to respondents' self-reported aversion to fees. Several variables were used to group respondents into homogeneous clusters, each likely to respond in 
similar ways to Corps pricing initiatives. To discover the optimal cluster or "solution," respondents were grouped in terms of the importance they assigned to price, their intentions based upon various fee schedules, and even the number of activities they enjoyed while on site. The pricing literature suggests that all these variables may influence price sensitivity.

However, none of the clusters formed using these variables seemed to explain the response patterns found within these data. Instead, the best "solution" was that created when respondents were clustered according to (a) the number of trips they had taken to a Corps project over the past 12 months, (b) the number of hours spent while onsite, and (c) the perceived quality of the facilities at the Corps site they had visited. Although these variables are not directly related to price sensitivity, clusters undertaken on this basis offered considerable insight regarding users' price sensitivity.

The cluster analyses were undertaken using the average linkage between groups and squared Euclidean distances. In other words, clusters were formed on the basis of the average distance between pairs of cases in different clusters. This method of clustering is preferred because of its reliance on pairs of cases. Two clusters were generated using these variables. Subsequent discriminant analysis supported the selection of these two clusters with almost all ( 97.4 percent) respondents falling into one or the other.

First of all, members of the two clusters did not differ in terms of their sociodemographic characteristics. They were remarkably comparable in terms of sex, household size, ethnicity, and household income. These results suggest that, for this group at least, such variables offer little insight into general price sensitivity. Group members did, however, differ in terms of their behavior patterns.

The Cluster I group seemed to possess all the characteristics of loyal and committed visitors. Those in the first cluster were likely to live in close proximity to the project at which their names were collected. Just over 60 percent lived within 20 miles of the project they were visiting on the day their name was taken. Members of the second cluster tended to live further away from the Corps project. Only 34 percent lived within 20 miles of the project, and 28.6 percent of the second group lived more than 60 miles from the project. Members of the first cluster were also likely to have made multiple trips to the Corps project over the past year. Just over three-fourths (75.2 percent) of this group made 11 or more trips to a Corps day-use area in the past 12 months. Only 2 (2.2) percent of the members of the second group had made more than 11 visits during that time period, and none had made more than 20 visits over the past year.

Finally, members of the first cluster reported considerable commitment to their favorite Corps site. Three-fourths ( 76.6 percent) of the cluster's members reported that they preferred the day-use area at which contact had been made over others in the area. Fewer ( 52.3 percent) of the second group reported such commitment. Consequently, it was assumed that the 
first cluster most appreciated the value of Corps day-use facilities and would, therefore, be willing to pay for them as a result. However, it seems that this group is less supportive of fees at Corps projects than its counterpart.

The first seems to be the more price sensitive of the two clusters (Figure 1). This pattern was perhaps unexpected based on the characteristics of this cluster's members. They had reported greater affiliation with and commitment to the Corps sites included in the study. However, the first cluster's members strongly disagreed with the suggestion that fees be charged and reported considerable unwillingness to pay such fees. They also agreed with the statement "If the Corps charged a fee, I would no longer visit their day-use areas" (Figure 1). Further, if fees were instituted, this first cluster expected to pay significantly less for all the boat ramp and picnic packages described in the survey (Figures 2 and 3 ).

The second cluster reported greater (though limited) support for Corps pricing initiatives and expected to pay considerably higher fees. Perhaps this group's members treat a visit to Corps sites as a special occasion. They tend to visit less often and generally travel greater distances to do so. The often sporadic nature of their visits and the greater distance traveled may have diminished the importance of fee levels for this group.

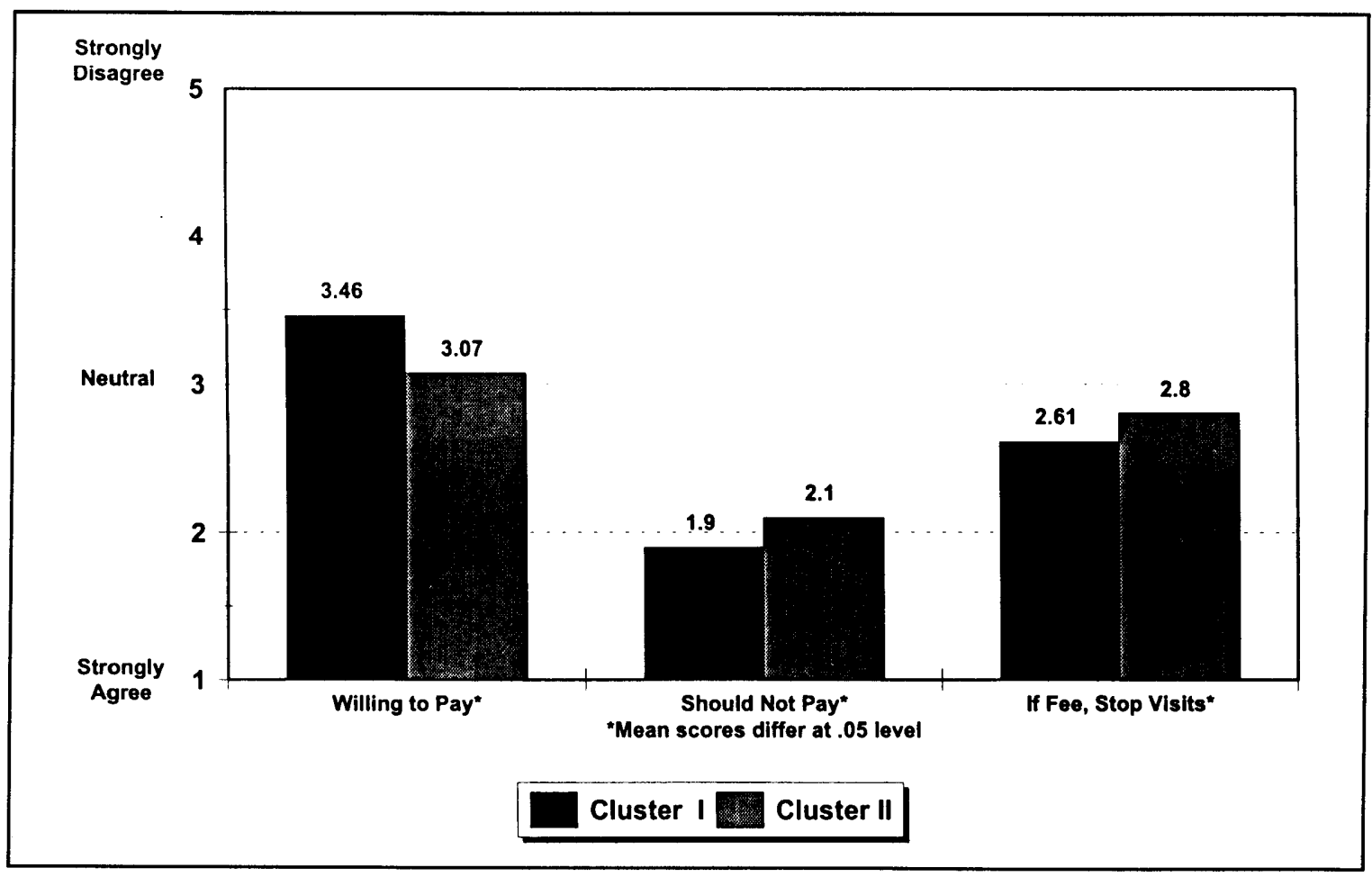

Figure 1. Cluster differences in reaction to charging of fees 


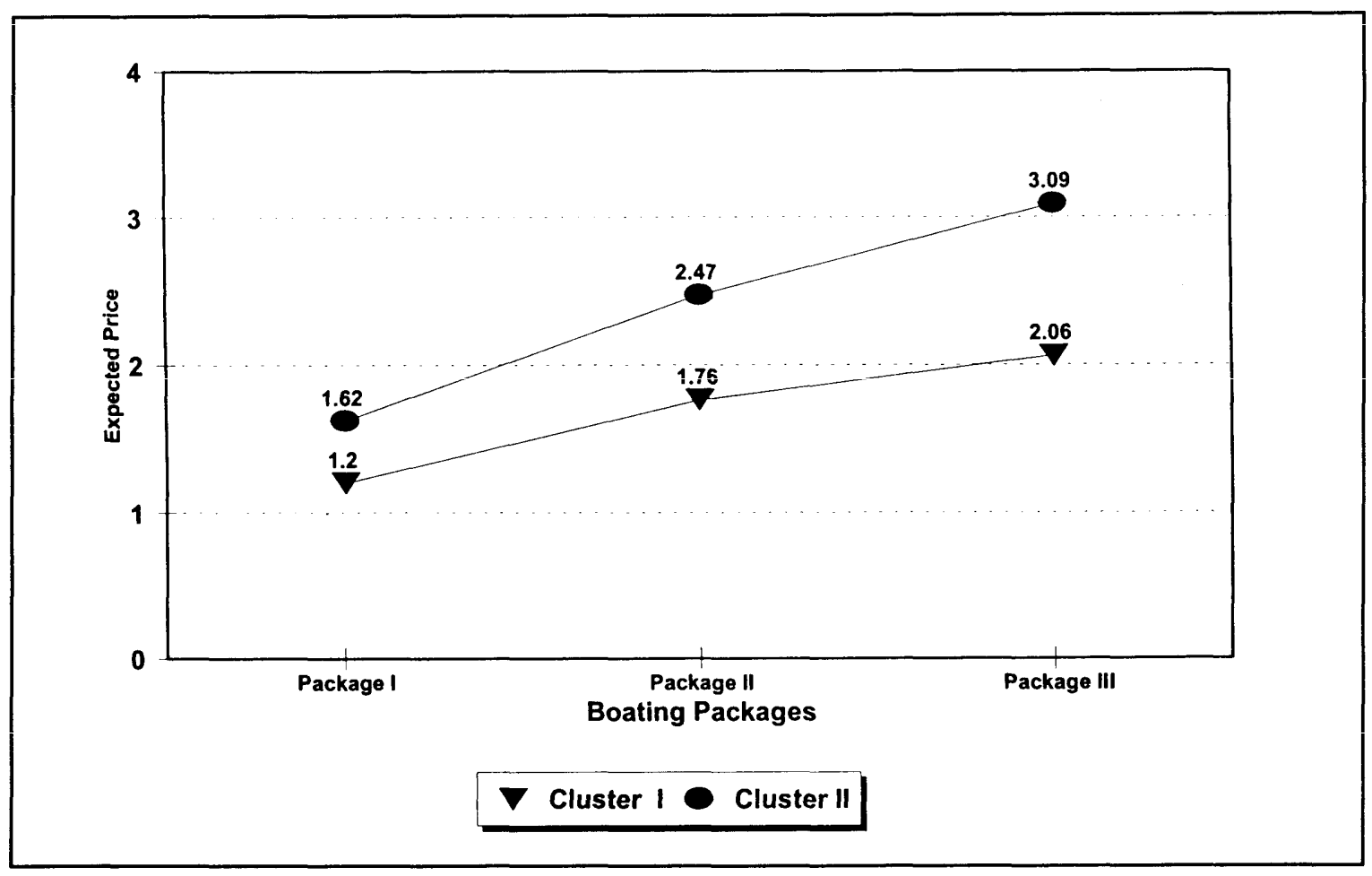

Figure 2. Price expectation for boating packages, by cluster

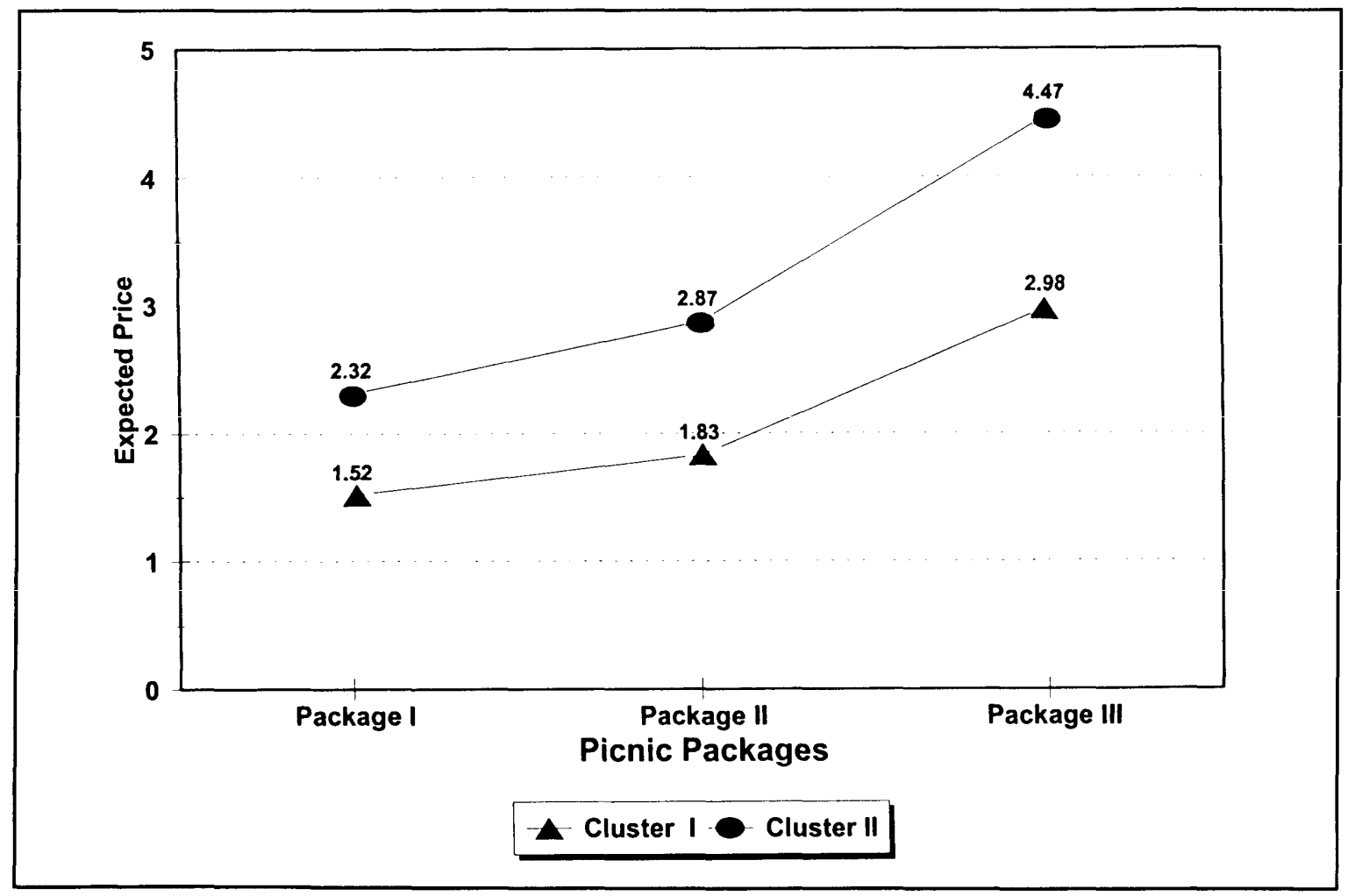

Figure 3. Price expectation for picnic packages, by cluster 
It should be noted, however, that although the second cluster expected to pay more for a visit than did its counterpart, members were still of the opinion that they should not pay such fees. Like those in Cluster I, many reported that they would no longer visit Corps areas if fees were charged.

Analyses were then undertaken to determine the distribution of cluster members across the survey sites. There was a relatively even distribution at the sites with the exception of Canyon Lake, Strom Thurmond, and Mendocino. The first cluster made up less than one-third (28.8 percent) of respondents at Canyon, while its members made up more than twice that number (64.2 percent) at Mendocino and Strom Thurmond (60.7 percent). 


\section{Discussion and Recommendations}

Corps day-users clearly value their experiences at the projects included in this survey. They pursue a variety of activities while onsite and often travel considerable distances to do so. Their evaluation of Corps facilities are almost uniformly positive, and they often report considerable loyalty to Corps sites. Unfortunately, the positive disposition toward the Corps day-use areas does not translate into an acceptance of fees for those areas. Several recommendations arise from this finding. It should be noted that these recommendations are based on related literature from the economics, leisure, and marketing fields.

Several of these recommendations focus on the provision of information to users. Typically, the only piece of information provided to users is the level of a fee. It is perhaps little wonder that users often respond negatively to such information. The recommendations offered here suggest that a promotional strategy should be developed around pricing initiatives. Fees and fee levels must be justified if they are to be accepted by user groups.

\section{Recommendation I: Equity and the Charging of Fees}

The question of charging fees must first deal with the issue of "equity." Equity is concerned with "what ought to be." In this case, equity norms among Corps users currently suggest that fees of any kind are inappropriate. As such, new fees (at any level) may meet with considerable resistance. Efforts to price Corps day-use facilities must first consider the equity issue if they are to be successful. 


\section{Recommendation I A}

The charging of fees must be justified to users, and the need for fees must be established in the minds of Corps users. This may be done in one of two basic ways. First, the costs of providing current service offerings should be publicized. Cost of service provision has been shown to alter users' price expectations and willingness-to-pay levels. It seems that as costs are made clear, users are more likely to recognize the need for fees to cover all or part of these costs.

\section{Recommendation I B}

Second, consequences of the payment of fees (or lack of payment) should be explained. Results of this study suggest that if the users benefit from the payment of fees, then these benefits should be fully explained. Price expectations may rise as a result. For example, receipts might outline how each fee is allocated within the project. The message on the receipt might be worded thus: "Thank you for your fee. We want you to know that we will be using your money to help make your stay with us even more pleasant. Sixty percent of your fee will be devoted to maintaining our day-use areas, twenty percent will buy new shelters for our picnic areas, and the rest will be used to provide staff for security patrols around the project." In this way, the user is made aware of all the benefits to be enjoyed as a result of paying that fee.

\section{Recommendation I C}

The results of this and previous fee studies clearly indicate that the disposition of the fee revenue is an important factor in people's acceptance of fees. Users of facilities prefer that fee revenue be used to maintain and improve the area where the fee was collected. If fees are allocated to other areas or projects that are not used by the people paying the fee, it is much more difficult to justify fees to users. Therefore, projects should exercise as much control over the allocation of fees as is allowed by the legislation authorizing the collection of fees.

\section{Recommendation I D}

All of these techniques might be combined to justify new pricing initiatives. For example, brochures might outline the amount of costs to maintain a site, then discuss how fees will be used to maintain or improve popular sites. This technique can be especially effective if costs are expressed in terms that are personally relevant to the individual user. If a user understands that it costs about $\$ 5$ a day to provide a favorite site, then a fee of $\$ 3$ may seem more reasonable and fair. 


\section{Recommendation I E}

It is recommended that staff members be fully involved in promoting the need for fees. Survey results suggest that users value interactions with staff. It is likely that they will communicate any questions or complaints regarding fees to staff. Such contact offers two important opportunities that should not be wasted. First, it will offer an opportunity for staff members to justify the fees using the techniques suggested here. Staff members must be briefed in the need for the fees, the benefits arising from the payment of fees, and the disposition of such fees. Contact with staff members often generates considerable word-of-mouth communication among users. If this contact is positive, then users themselves will be spreading the word on the need for new fee initiatives.

Contact with users will also enable staff members to gather information on public reaction to the fees. Users will provide a rich source of information on the impact of fees on visitation levels and on general perceptions of the fee program. This information will be particularly critical as fees are first being initiated.

\section{Recommendation II: Value and the Setting of Fees}

Price-setting strategies must consider the notion of "value" in the mind of the user. Value is generally defined as perceived benefits as moderated by the costs the user believes he or she paid to enjoy those benefits. The greater the benefits enjoyed or the lower the costs, the greater the value for the user. As noted, there seems little question that users currently recognize the value they enjoy as a result of visiting Corps day-use areas. Ratings of Corps facilities were uniformly high among all respondents, and feelings toward the Corps sites seem very positive. Strategies should be developed that draw attention to this sense of value.

\section{Recommendation II A}

It is recommended that managers focus their attention on those services most sought by users. As noted earlier, these services include clean restrooms, swimming beaches, adequate parking, and so on. Reference to these services helps draw attention to the value of the experience to be enjoyed once the fee has been paid. For example, promotions might invite users to "Come enjoy our fifteen beaches, one thousand miles of lake front, playgrounds for the children, and a shady tree for you. All this for only ...." Corps areas offer almost resort-like conditions and should be promoted accordingly. When considered in this context, a small fee may seem more reasonable to even the most irate user. 


\section{Recommendation II B}

The negative attitudes toward fees and the expressed behavioral intention by many current users to no longer visit Corps day-use areas if a fee system is implemented must be factored into the fee-setting decision process. The potential loss in revenue associated with setting the fee "too high" is greater than the potential loss in revenue associated with setting the fee "too low" at four of the six projects studied. Consequently, the Corps may want to be conservative in setting the initial fee levels. This may be advantageous for three reasons. First, current users' negative attitude toward fees is a major problem that needs to be addressed as the fee system is implemented. Adding to this problem with additional complaints about the magnitude of the fees may not be prudent. Second, setting fees at a conservative level would minimize the adverse impact on users with lower income levels and would allow them to adjust to the imposition of fees. Finally, lower fees would reduce the possibility of current users substituting nonfee areas for fee areas at projects where both exist in close proximity.

\section{Recommendation III: Choice and the Setting of Fees}

Users are likely to suffer from a phenomenon often called "reactance" as a result of being asked to pay fees where none had been charged earlier. This phenomenon has also been called the "Outrage Factor." Reactance is likely to occur when a fee is placed on a resource and users are forced to pay a fee or lose access to that resource. The loss of control users experience from such measures often results in complaint behavior, vandalism, and other forms of protest. One way to reduce the potential for reactance is to offer meaningful choices for users.

\section{Recommendation III A}

Pricing policies must offer pricing alternatives. Users must feel that they have some choice in the price they eventually pay to visit Corps sites. Price alternatives must recognize a user's particular needs. Results suggest that users vary in the amount of time they stay onsite, the number of times they visit a project in a given year, and so on. It is recommended that a pricing scheme be developed accordingly.

For example, half-day passes may be made available after 3:00 p.m., and season/annual passes should be available to frequent users. Those who visit Corps projects during traditional "shoulder" seasons could be rewarded with discounts. In this way, Corps administrators can stimulate visitation away from peak periods (thereby reducing congestion) and offer 
an additional option to user groups. Given such choices, users can select fee levels that best suit their own priorities.

Provision of choice offers an added benefit in that it aids users in selecting a fee type or fee level that is most acceptable to themselves and their own personal resource levels. In this way, low-income users are less likely to be displaced by user fees.

\section{Recommendation III B}

Respondents expected to pay more as basic services were enhanced. Price expectations for both the boat ramp and the picnic packages climbed significantly as services were added to the basic Corps product/facility. This finding presents both an opportunity and a challenge for price setting. In positive terms, it suggests that as services are enhanced, prices may also be elevated to reflect improved service quality. It also suggests, however, that users expect fees to vary with the level of service. Consequently, a "one-price-for-all-sites" pricing policy may create considerable dissatisfaction among users. If fees are instituted, they may expect that fee level to be linked with the quality of a site. As the quality varies, so too should the price for that site. 


\section{Appendix A Corps Day-Use Questionnaire}




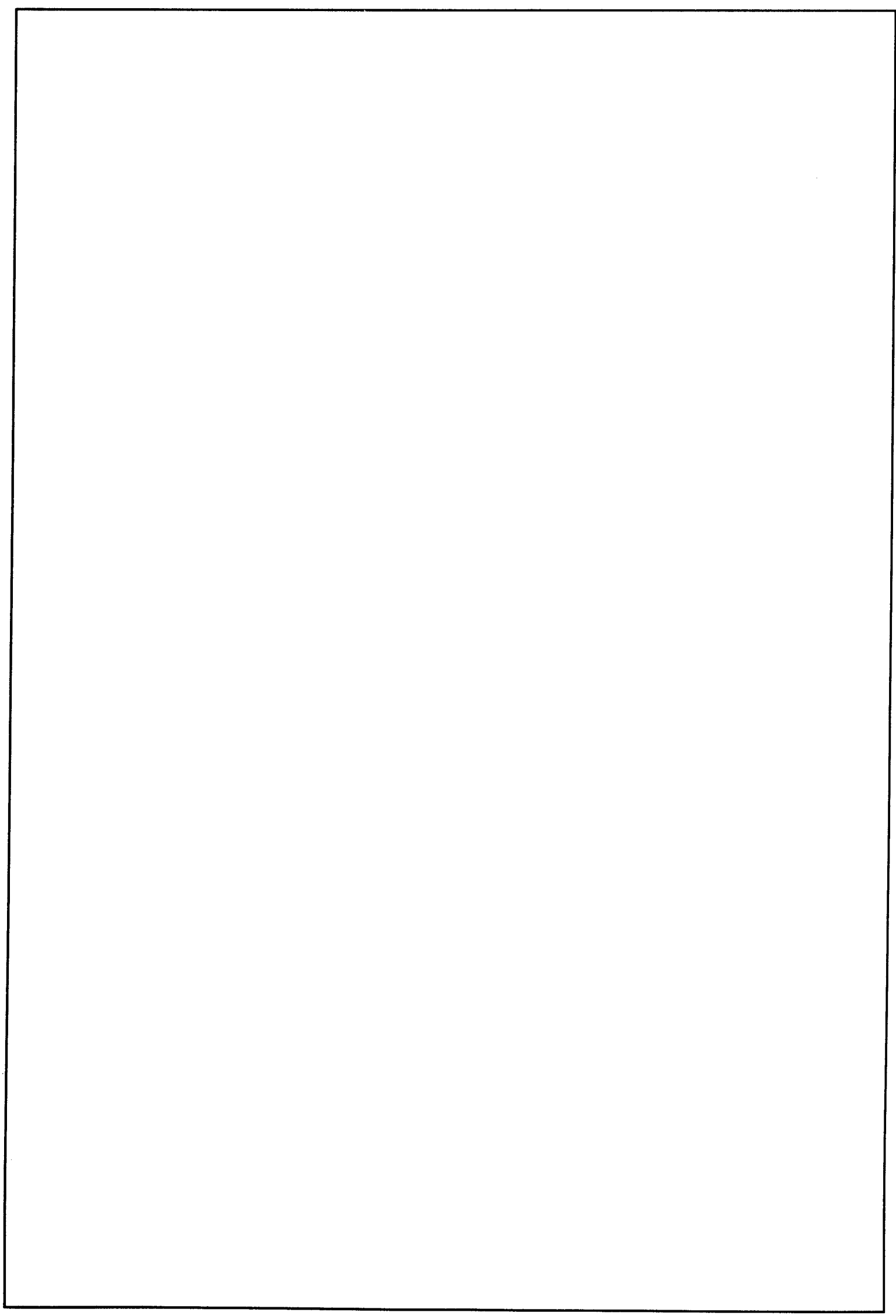




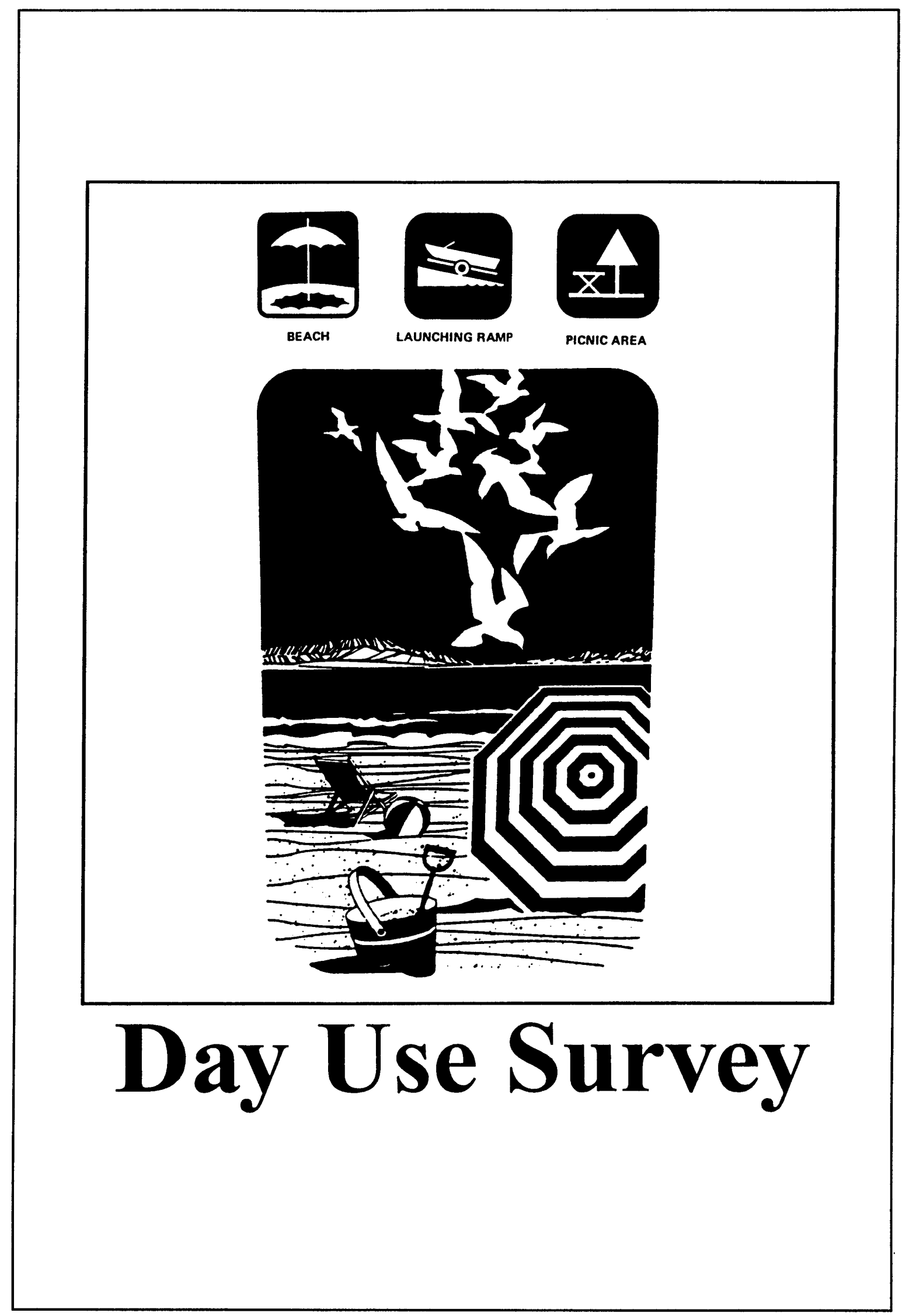




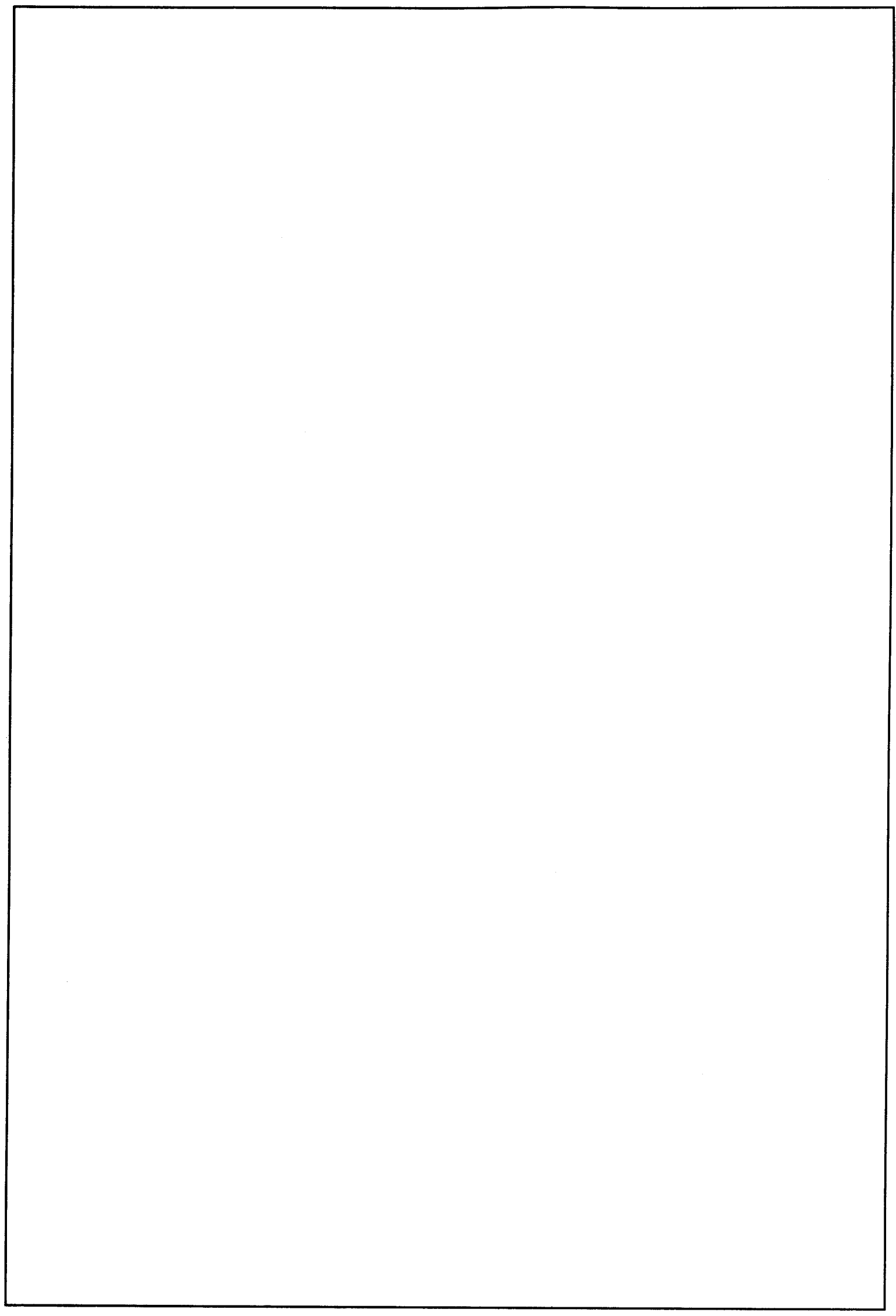


Section A. In this section we are interested in learning some general information about your use of day-use recreation areas located on lakes or reservoirs. For the purpose of this questionnaire, day-use recreation areas are defined as picnic and other recreation areas, including boat launching areas, where recreational use is allowed during the day. These areas may be closed overnight, except for fishing or boat ramp use. Camping overnight is not allowed at these day-use recreation areas.

1. What recreational activities do you or other members of your party usually participate in while visiting day-use recreation areas located on lakes or reservoirs? (please $\square$ all items that apply)
1. D relaxing
2. $\square$ swimming
3. $\square$ walking/hiking
11. $\square$ jet skiing
4. driving for pleasure
12. $\square$ windsurfing/sailboarding
5. $\square$ sunbathing
13. $\square$ motor boating
14. $\square$ sailing
6. ㅁ picnicking
15. $\square$ waterskiing
16. $\square$ fishing
7. $\square$ observing/photographing wildlife or nature
17. $\square$ volleyball
18. $\square$ softball/baseball/frisbee
8. $\square$ bicycling
19. $\square$ soccer/football
9. $\square$ horseback riding
20. $\square$ horseshoes
10. $\square$ canoeing/kayaking
21. u using playgrounds
22. $\square$ other activities (please list) 
2. How important is each item, listed below, for you personally when deciding which day-use recreation area located on lakes or reservoirs to visit? (please 0 one box for each item)

\begin{tabular}{lccc} 
& $\begin{array}{c}\text { Very } \\
\text { Important }\end{array}$ & $\begin{array}{c}\text { Somewhat } \\
\text { Important }\end{array}$ & $\begin{array}{c}\text { Not } \\
\text { Important }\end{array}$ \\
\hline 1. Swimming beach & $\square$ & $\square$ & $\square$ \\
2. Playgrounds & $\square$ & $\square$ & $\square$ \\
3. Picnic tables near beach & $\square$ & $\square$ & $\square$ \\
4. Covered picnic tables & $\square$ & $\square$ & $\square$ \\
5. Group shelters & $\square$ & $\square$ & $\square$ \\
6. Cleanliness of rest rooms & $\square$ & $\square$ & $\square$ \\
7. Hot showers & $\square$ & $\square$ & $\square$ \\
8. Adequate parking & $\square$ & $\square$ & $\square$ \\
9. Boat ramps & $\square$ & $\square$ & $\square$ \\
10. Boat docks or moorings & $\square$ & $\square$ & $\square$ \\
11. Controlled access to day-use area & $\square$ & $\square$ & $\square$ \\
1.e. gatehouse with attendant) & $\square$ & $\square$ & $\square$ \\
12. Fish cleaning station & $\square$ & $\square$ & $\square$ \\
13. Bicycle path & $\square$ & $\square$ & $\square$ \\
14. Hiking/Walking Trails & $\square$ & $\square$ & $\square$ \\
15. Interpretive/Nature Trails & $\square$ & $\square$ & $\square$ \\
16. Security patrols & $\square$ & $\square$ & $\square$ \\
17. Scenery & $\square$ & $\square$ & $\square$ \\
18. Close to home & $\square$ & $\square$ & $\square$ \\
19. Remote location & $\square$ & $\square$ & $\square$ \\
20. Friendliness of staff & $\square$ & $\square$ & $\square$ \\
\hline
\end{tabular}


Section B. We obtained your name and address by stopping your vehicle as you departed a Corps of Engineers' day-use recreation area. In this section, we are interested in obtaining some information about the visit you made on the day we stopped your vehicle. Please think in terms of your visit to that day-use area on that day when answering the following questions. Information about that visit is enclosed on a separate sheet. Please review it before completing this section.

1. Including yourself, how many people were in your party on the day you visited the day-use recreation area where your vehicle was stopped? (please $\square$ only one item)
A. $\square 1$ (alone)
B. $\square 2$
C. $\square 3$
D. $\square 4$
E. $\square 5$
F. $\square 6$ or more

2. How many hours did you and your party spend at the day-use recreation area on the day your vehicle was stopped? (please $\square$ only one item)
A. $\square$ less than 1 hour
B. $\square 1$ to 2 hours
C. $\square 2$ to 4 hours
D. $\square 4$ to 6 hours
E. $\square 6$ to 8 hours
F. $\square 8$ to 10 hours
G. $\square 10$ or more hours 
3 Who was with you when you visited the day-use recreation area or. the dav your vehicle was stopped? (please $\square$ only one item)

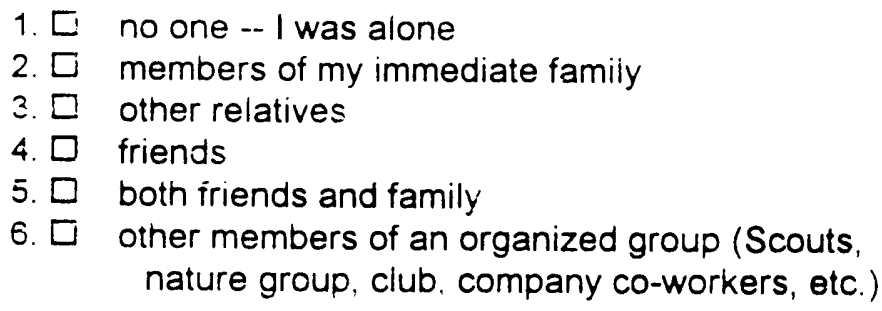

4. What recreational activities did you or other members of your party participate in at the day-use recreation area on the day your vehicle was stopped? (please $\square$ all items that apply)
1. $\square$ relaxing
2. $\square$ swimming
3. $\square$ walking/hiking
11. $\square$ jet skiing
4. $\square$ driving for pleasure
12. $\square$ windsurfing/sailboarding
13. $\square$ motor boating
14. $\square$ sailing
5. $\square$ sunbathing
6. $\square$ picnicking
15. $\square$ waterskiing
16. $\square$ fishıng
7. observing/photographing wildlife or nature
8. $\square$ bicycling
17. $\square$ volleyball
18. softball/baseball/frisbee
19. $\square$ soccer/football
๑. $\square$ horseback riding
10. $\square$ canoeing/kayaking
20. $\square$ horseshoes
21. $\square$ using playgrounds
22. $\square$ other activities (please list) 
5. Overall, how would you personally rate the quality of the facilities at the day-use recreation area where your vehicle was stopped? (please $\square$ only one item)
1. $\square$ Poor
2. $\square$ Fair
3. $\square$ Good
4. $\square$ Very Good
5. $\square$ Excellent

6. What is the one way travel distance from your home to the day-use recreation area where your vehicle was stopped? (please $\square$ only one item)

1. $\square$ less than 5 miles

2. 5 to 10 miles

3. 11 to 20 miles

4. $\square 21$ to 30 miles

5. 31 to 40 miles
6. $\square \quad 41$ to 50 miles

7. $\square 51$ to 60 miles

8. $\square 61$ to 70 miles

9. $\square$ more than 70 miles 
7. Day-use recreation visits involve several different types of expenses. About how much were your total expenses for the trip you made to the day-use recreation area where your vehicle was stopped? Please do not report equipment purchases. If you shared expenses with others, only report your share of the expenses. (please fill in all the blanks; write in a zero (0) if you had no expenses in a particular category)

1. Auto and RV expenses (gas and oil for vehicle, repairs, tolls, auto parts, parking fees)

\section{$\$$}

2. Food and beverages (restaurants, groceries, ice, etc.) ........ $\$$

3. Boating expenses (gas and oil, boat rental, boat repairs and parts)

$\$$

4. Fishing expenses (temporary license just for the trip, bait, charter fee)

$\$$

5. Miscellaneous expenses (maps and directories, film, bug spray, general clothing, services)

6. Other activity expenses (recreation equipment rental, guide services, other recreation activities)

7. Other (please list)

$\$$

8. TOTAL (lines 1 through 7 )

$\$$

8. Your cost of visiting day-use recreation areas could go up or down. For example, the cost of gasoline could increase, thus making your visit more expensive. Would you have still taken the trip to the dayuse recreation area where your vehicle was stopped if the total cost of your trip had been $\$$ more than the expenses calculated in the previous question? (please $\square$ yes or no)

1. $\square$ Yes

2. $\square$ No 
9. In the first section, we asked how important certain items are when you choose a day-use recreation area. Now we would like you to rate the quality of each item, listed below, for the day-use recreation area where your vehicle was stopped. (For each item listed, circle the number that best describes your opinion) Note: Some items may not be available at the day-use area you visited.

\begin{tabular}{lcccccc} 
& Excellent & $\begin{array}{c}\text { Very } \\
\text { Good }\end{array}$ & Good & Fair & Poor & $\begin{array}{c}\text { Nol available } \\
\text { or could not } \\
\text { jodge }\end{array}$ \\
\hline 1. Swimming beach & 1 & 2 & 3 & 4 & 5 & 6 \\
2. Playgrounds & 1 & 2 & 3 & 4 & 5 & 6 \\
3. Picnic tables near beach & 1 & 2 & 3 & 4 & 5 & 6 \\
4. Covered picnic tables & 1 & 2 & 3 & 4 & 5 & 6 \\
5. Group shelters & 1 & 2 & 3 & 4 & 5 & 6 \\
6. Cleanliness of rest rooms & 1 & 2 & 3 & 4 & 5 & 6 \\
7. Hot showers & 1 & 2 & 3 & 4 & 5 & 6 \\
8. Adequate parking & 1 & 2 & 3 & 4 & 5 & 6 \\
9. Boat ramps & 1 & 2 & 3 & 4 & 5 & 6 \\
10. Boat docks or moorings & 1 & 2 & 3 & 4 & 5 & 6 \\
11. Controlled access to day-use & & & & & & \\
area (i.e. gatehouse with & 1 & 2 & 3 & 4 & 5 & 6 \\
attendant) & 1 & 2 & 3 & 4 & 5 & 6 \\
12. Fish cleaning station & 1 & 2 & 3 & 4 & 5 & 6 \\
13. Bicycle path & 1 & 2 & 3 & 4 & 5 & 6 \\
14. Hiking/Walking trails & 1 & 2 & 3 & 4 & 5 & 6 \\
15. Interpretive/Nature trails & 1 & 2 & 3 & 4 & 5 & 6 \\
16. Security patrols & 1 & 2 & 3 & 4 & 5 & 6 \\
17. Scenery & 1 & 2 & 3 & 4 & 5 & 6 \\
18. Friendliness of staff & & & & &
\end{tabular}


10. How important was each reason, listed below, for you personally when planning your visit to the day-use recreation area where your vehicle was stopped? (please circle one number for each reason)

\begin{tabular}{|c|c|c|c|c|c|}
\hline & $\begin{array}{l}\text { Very } \\
\text { Important } \\
\end{array}$ & $\begin{array}{l}\text { Somewhat } \\
\text { Important }\end{array}$ & Neutral & $\begin{array}{l}\text { Somewhat } \\
\text { Unimportant }\end{array}$ & $\begin{array}{l}\text { Nok at all: } \\
\text { Important }\end{array}$ \\
\hline 1. Relaxing near the water & 1 & 2 & 3 & 4 & 5 \\
\hline 2. Spending time on a boat & 1 & 2 & 3 & 4 & 5 \\
\hline 3. Opportunity to fish & 1 & 2 & 3 & 4 & 5 \\
\hline $\begin{array}{l}\text { 4. Being together with family } \\
\text { and friends }\end{array}$ & 1 & 2 & 3 & 4 & 5 \\
\hline 5. Being physically active & 1 & 2 & 3 & 4 & 5 \\
\hline 6. Staying close to home & 1 & 2 & 3 & 4 & 5 \\
\hline 7. Being out-of-doors & 1 & 2 & 3 & 4 & 5 \\
\hline $\begin{array}{l}\text { 8. Returning to my favorite } \\
\text { day-use recreation area }\end{array}$ & 1 & 2 & 3 & 4 & 5 \\
\hline 8. Change in daily routine & 1 & 2 & 3 & 4 & 5 \\
\hline
\end{tabular}

11. Which of the following statements best describes how well you personally like the Corps of Engineers' day-use recreation area where your vehicle was stopped? (please $\square$ only one item)

1. $\square \quad$ I would not go elsewhere in this region.

2. $\square$ I would go elsewhere, but I prefer this day-use area

3. It makes no difference to me whether I use this dayuse area or another area.

4. $\square \quad$ I would come here again, but I would prefer to go eisewhere.

5. $\square$ I would not come here again. 
Section C. In this section we are interested in how recreation dayuse fees would affect your visits to the Corps recreation day-use area where you vehicle was stopped.

1. How many total trips did you personally take in the past 12 months to the day-use area where your vehicle was stopped? (please fill in the blank)

total trips

2. There is legislation before Congress that would establish day-use fees at Corps of Engineer day-use areas, like the one where your vehicle was stopped. The Corps is interested in your views on recreation day-use fees. Suppose a recreation day-use fee was charged at the recreation day-use area where your vehicle was stopped, and at other similar Corps-operated day-use recreation areas nationwide. If the fee was $\$$ _ per vehicle per day, or $\$$ __ per vehicle for an annual pass that would allow you to use all the day-use areas located on this lake for one year, which option would you personally choose? (please $\square$ one response)

1. I would pay the per-vehicle per-day fee

2. I would purchase the season pass

3. $\square$ Neither--I would not visit Corps day-use areas anymore (Go to Section D)

3. About how many visits would you personally have made in the last 12 months to the day-use recreation area where your vehicle was stopped if the fee levels mentioned in question 2 had been charged? Please give your best estimate. (fill in the blank)

total visits I would have made in the last 12

months at the stated fee levels. 
Section D. In this section we want to learn more about your personal opinions about day-use fees.

1. How important is cost to you personally when you choose: (please circle one number for each reason)

\begin{tabular}{lccccc} 
& $\begin{array}{c}\text { Very } \\
\text { Important }\end{array}$ & $\begin{array}{c}\text { Somenthat } \\
\text { Important }\end{array}$ & Neutral & $\begin{array}{c}\text { Somewhat } \\
\text { Unimportant }\end{array}$ & $\begin{array}{c}\text { Not at at } \\
\text { Important }\end{array}$ \\
\cline { 2 - 6 } A. Recreation Areas & 1 & 2 & 3 & 4 & 5 \\
B. Recreation Activities & 1 & 2 & 3 & 4 & 5 \\
C. Recreation Equipment & 1 & 2 & 3 & 4 & 5
\end{tabular}

2. Have you personally visited any day-use areas located on lakes or reservoirs in this region during the last 12 months where a dayuse fee was charged? (please $\square$ yes or no)

1. $\square$ Yes

2. $\square$ No 
3. Although the Corps does not charge day-use recreation fees, we are interested in your views on day-use fees at Corps of Engineers' day-use areas. Please circle the number that best describes how much you personally agree or disagree with each statement below. (Circle one number for each statement)

\begin{tabular}{|c|c|c|c|c|c|}
\hline & $\begin{array}{c}\text { Strongly } \\
\text { Agree }\end{array}$ & $\begin{array}{c}\text { Somewhat } \\
\text { Agree }\end{array}$ & Neutral & $\begin{array}{c}\text { Somewhat } \\
\text { Disagree }\end{array}$ & $\begin{array}{l}\text { Strongly } \\
\text { Disagree }\end{array}$ \\
\hline $\begin{array}{l}\text { 1. I shoufd not pay a fee to visit } \\
\text { Corps of Engineers' day-use } \\
\text { areas. }\end{array}$ & 1 & 2 & 3 & 4 & 5 \\
\hline $\begin{array}{l}\text { 2. I am willing to pay a fair day- } \\
\text { use fee when using Corps day- }\end{array}$ & 1 & 2 & 3 & 4 & 5 \\
\hline
\end{tabular}

If foes are charged:

3. I should not pay a day-use foe unless I use special facilities like boat ramp, group shelters and bathhouse.

4. I should pay a day-use fee that covers operation and maintenance costs.

5. I support day-use foes if they to used to maintain my favorite day-use area.

1

2

3

4

5

6. I expect to pay higher fees when using modernized dayuse areas.

7. Elderly visitors should receive discounts when they use Corps day-use areas.

8. Higher day-use fees on weekends and holidays would encourage me to visit more often during the woek.

8. If the Corps charged a day-use foe, I woutd no longer visit their day-use aroas.

\begin{tabular}{lllll}
1 & 2 & 3 & 4 & 5 \\
1 & 2 & 3 & 4 & 5 \\
1 & 2 & 3 & 4 & 5 \\
1 & 2 & 3 & 4 & 5 \\
1 & 2 & 3 & 4 & 5 \\
1 & 2 & 3 & 4 & 5 \\
\hline
\end{tabular}


4. Did your party use a boat on the day you visited the Corps day-use area where your vehicle was stopped? (please $\square$ yes or no)

\section{1. $\square$ Yes \\ 2. $\square$ No $\rightarrow$ (If no, go to question 7 )}

5. What is a "fair" fee you personally would pay for each of the following Corps of Engineers boat ramp "packages" (please fill in the blank for each package)

\begin{tabular}{|l|c|}
\hline Boat Ramp Package One & Excluding any discount, "fair" fee I would \\
Boat ramp with ample parking. & pay for Boat Ramp Package One is \\
& $\$ \quad$ per vehicle per day \\
\hline
\end{tabular}

\section{Boat Ramp Package Two}

Boat ramp Packago One plus security lights, courtesy dock. and fish cleaning station.

Excluding any discount, a "fair" fee I would pay for Boat Ramp Package Two is $\$$ per vehicle per day

\begin{tabular}{l|c|}
$\begin{array}{l}\text { Boat Ramp Package Three } \\
\text { Boat ramp Package Two plus } \\
\text { a gate house with attendant to } \\
\text { control access. }\end{array}$ & pxcluding any discount, a "fair" fee I would \\
& \$_por bohicle per day \\
\hline
\end{tabular}

6. Which of the three Corps of Engineers Boat Ramp "packages" presented in Question 5 do you personally prefer? (please $\square$ only one item)

1. $\square$ Boat Ramp Package One

2. Boat Ramp Package Two

3. $\square$ Boat Ramp Package Three 
7. What is a "fair" fee you personally would pay for each of the following Corps of Engineers' Picnic "packages"? (please fill in the blank for each package)

\begin{tabular}{l|l}
\hline Picnic Package One & Excluding any discount, a "fair" fee I \\
An area with uncovered picnic \\
tables, ample parking, swimming \\
$\begin{array}{l}\text { beach (no llfeguard), rest rooms with } \\
\text { llush tollets, and a boat ramp. }\end{array}$ & would pay for Picnic Package One is \\
\end{tabular}

\begin{tabular}{|l|l|}
\hline Picnic Package Two & Excluding any discount, a "fair" fee I \\
Picnic Package One plus controlled & would pay for Picnic Package Two \\
access (a gate house with attendant). & \begin{tabular}{l} 
is $\$$ \\
\hline
\end{tabular}
\end{tabular}

\section{Picnic Package Three}

Picnic Package Two plus covered picnic tables with electricity at each site and restrooms with hot showers.
Excluding any discount, a "fair" fee I would pay for Picnic Package Three is $\$$ per vehicle per day

8. Which of the three Picnic "packages" presented in Question 7 do you personally prefer? (please $\square$ only one item)
1. $\square$ Picnic Package One
2. $\square$ Picnic Package Two
3. $\square$ Picnic Package Three 
9. If fees were charged at Corps of Engineers' day-use areas, the money collected should be: (please $\square$ only one item)

1. $\square$ used to maintain or improve the day-use area where the fee was collected.

2. u used to maintain or improve any Corps dayuse area.

3. $\square$ used to maintain or improve any Corps recreation area (campground, scenic overlooks, etc.).

4. used to operate any Corps program, such as flood control.

5. $\square$ returned to the U.S. Treasury.

6. $\square$ other (please list) 
Section E. In this section we would like to ask you some questions about your background to help us compare your answers to those of other people. We stress that all your answers are strictly confidential.

1. Including yourself, how many people live in your household? (please $\square$ only one item)
1. ㅁ One, just me
4. ㅁ 4
2. 2
5. ㅁ 5 or more people
3. $\square 3$

2. What is your sex? (please $\square$ female or male)
1. $\square$ Female
2. $\square$ Male

3. What is your age? (please $\square$ only one item)
1. $\square$ less than 20 years old
4. $\square 40$ to 49 years
2. 20 to 29 years
5. ㅁ 50 to 59 years
3. $\quad 30$ to 39 years
6. $\square 60$ or more years

4. What is the highest level of formal education you have attained? (please $\square$ only one item)

1. $\square \quad$ Eight years or less

2. $\square$ Some high school

3. High school graduate or equivalent

4. Some college or technical school

5. $\square \quad$ B.A. degree or equivalent

6. $\square$ M.A. degree or equivalent

7. Advanced degree (M.D., PhD., etc.) 
5. With respect to your current occupation, are you: (please $\square$ all items that apply)

1. $\square$ Unpaid homemaker

5. $\square$ Fully retired

2. Working full-time outside home

3. W Working part-time outside home

6. Part-time student

4. $\square$ Semi-retired, working part-time

7. $\square$ Full-time student

8. Not presently employed

6. How would you describe your racial/ethnic background? (please $\square$ only one item)
1. $\square$ American Indian
4. Caucasian
2. Asian
5. $\square$ Hispanic
3. B Black
6. Other (please specify)

7. What was your total gross household income for 1992? (please $\square$ only one item)

1. $\square$ less than $\$ 5,000$

2. $\$ 5,000$ to $\$ 9,999$

3. $\$ 10,000$ to $\$ 14,999$

4. ㄴ $\$ 15,000$ to $\$ 19,999$

5. $\$ 20,000$ to $\$ 24,999$

6. $\$ 25,000$ to $\$ 29,999$

7. $\$ 30,000$ to $\$ 34,999$

8. $\$ 35,000$ to $\$ 39,999$
9. $\$ 40,000$ to $\$ 44,999$
10. $\$ \$ 45,000$ to $\$ 49,999$
11. $\$ 50,000$ to $\$ 59,999$
12. $\$ \$ 60,000$ to $\$ 69,999$
13. $\$ 70,000$ to $\$ 79,999$
14. $\$ 80,000$ to $\$ 89,999$
15. $\$ \$ 90,000$ to $\$ 99,999$
16. $\$ \$ 100,000$ or more

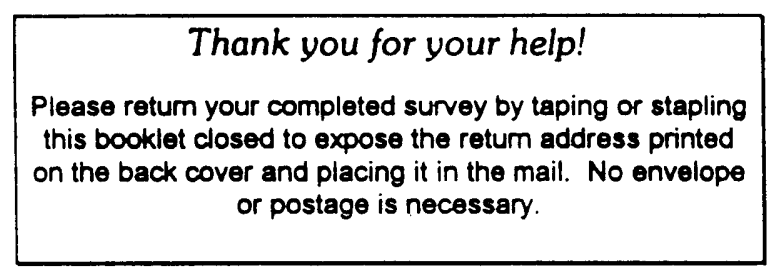

16 


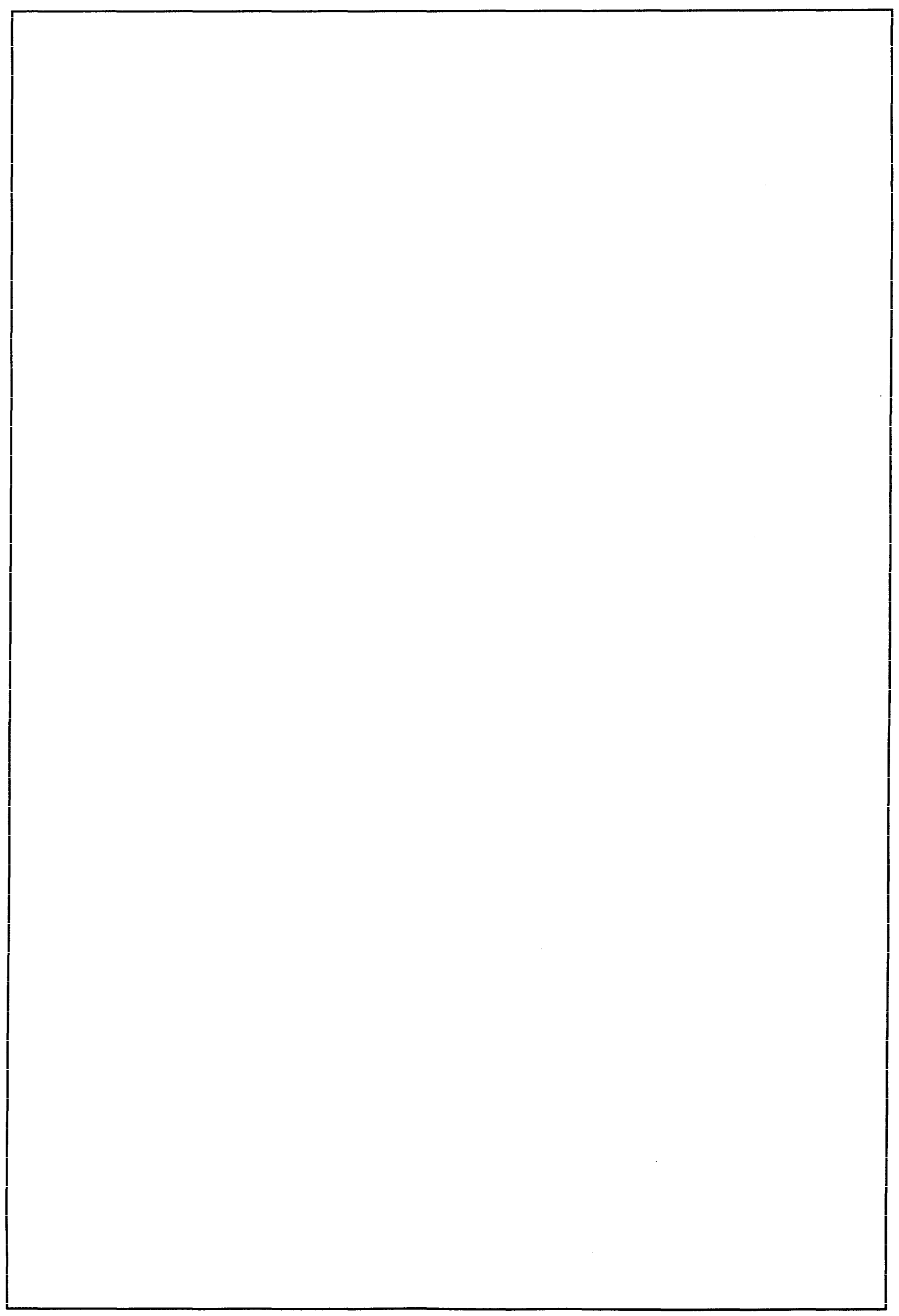




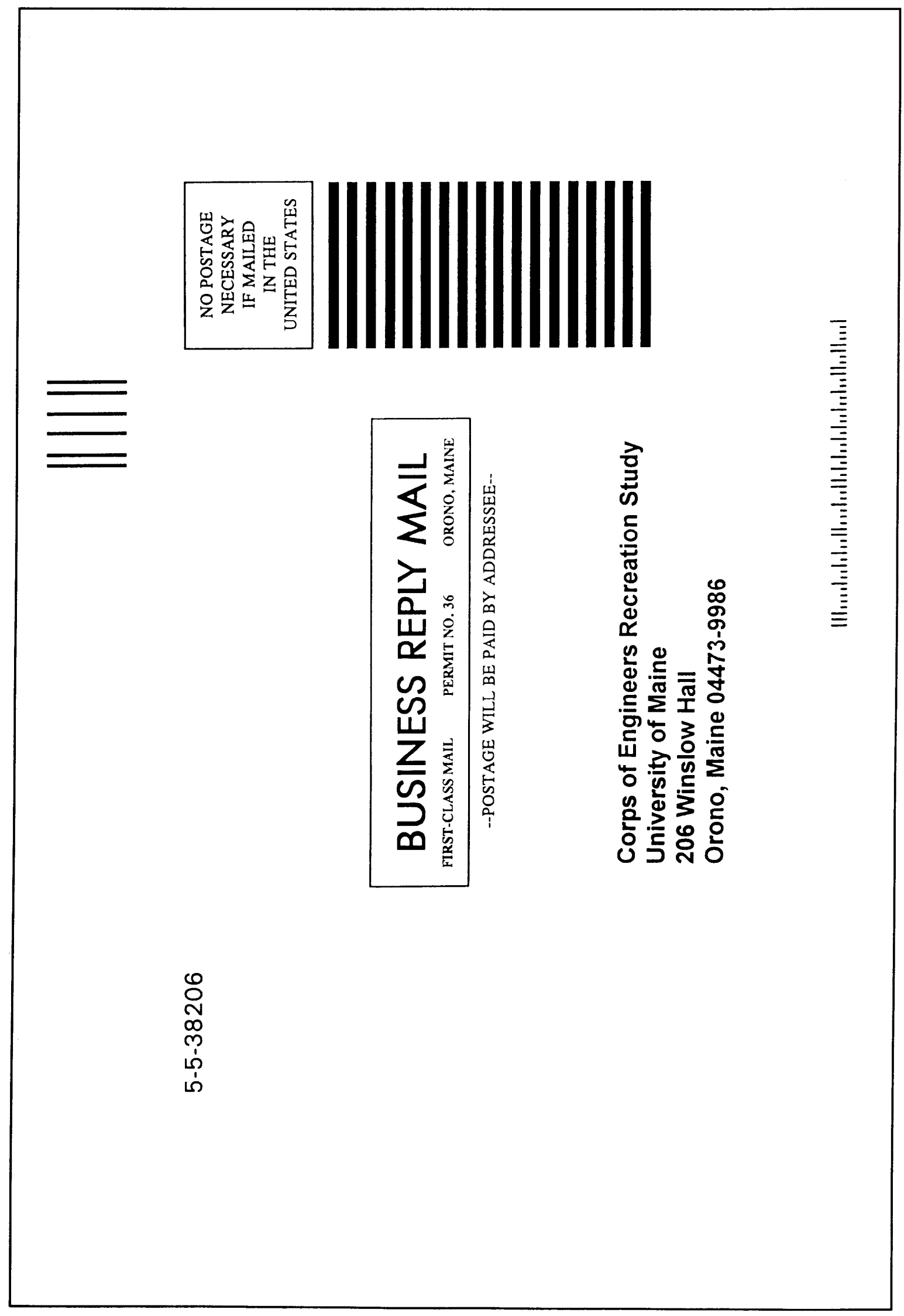




\section{Appendix B Sampling Information}




\begin{tabular}{|c|c|c|c|c|c|}
\hline \multirow{2}{*}{\multicolumn{6}{|c|}{$\begin{array}{l}\text { Table B1 } \\
\text { Sample Allocations for Corps Day-Use Study, by Project } \\
\text { Strom Thurmond Lake Day-Use Sample' }\end{array}$}} \\
\hline & & & & & \\
\hline \multirow[b]{2}{*}{ Area } & \multirow[b]{2}{*}{ \# Vehicles } & \multirow[b]{2}{*}{$\%$ of Total } & \multicolumn{3}{|c|}{ Sample Size } \\
\hline & & & Area Total & Weekday & Weekend \\
\hline Lake Springs & 16,894 & 72 & 334 & 134 & 200 \\
\hline Clarks Hill & 6,502 & 28 & 128 & 51 & 77 \\
\hline Total & 23,396 & 100 & 462 & 185 & 277 \\
\hline \multicolumn{6}{|c|}{ Weekday Sample Size by Time } \\
\hline Area & 6-10 am & $10 \mathrm{am}-2 \mathrm{pm}$ & 2-6 pm & 6-10 pm & Total \\
\hline Lake Springs & 13 & 34 & 74 & 13 & 134 \\
\hline Clarks Hill & 5 & 13 & 28 & 5 & 51 \\
\hline Total & 18 & 47 & 102 & 18 & 185 \\
\hline \multicolumn{6}{|c|}{ Weekend Sample Size by Time } \\
\hline Area & 6-10 am & 10 am-2 pm & 2-6 pm & 6-10 pm & Total \\
\hline Lake Springs & 20 & 50 & 110 & 20 & 200 \\
\hline Clarks Hill & 8 & 19 & 42 & 8 & 77 \\
\hline Total & 28 & 69 & 152 & 28 & 277 \\
\hline \multicolumn{5}{|l|}{ Grand Total } & 462 \\
\hline \multicolumn{6}{|c|}{ Burnsville Lake Day-Use Sample ${ }^{1}$} \\
\hline \multirow[b]{2}{*}{ Area } & \multirow[b]{2}{*}{ \# Vehicles } & \multirow[b]{2}{*}{$\%$ of Total } & \multicolumn{3}{|c|}{ Sample Size } \\
\hline & & & Area Total & Weekday & Weekend \\
\hline Riffle Run & 8,775 & 67 & 310 & 109 & 202 \\
\hline Bulltown & 4,348 & 33 & 152 & 53 & 99 \\
\hline Total & 13,123 & 100 & 462 & 162 & 301 \\
\hline \multicolumn{6}{|c|}{ Weekday Sample Size by Time } \\
\hline Area & 6-10 am & $10 \mathrm{am}-2 \mathrm{pm}$ & $2-6 \mathrm{pm}$ & 6-10 pm & Total \\
\hline Riffle Run & 5 & 11 & 65 & 27 & 108 \\
\hline Bulltown & 3 & 5 & 32 & 13 & 53 \\
\hline Total & 8 & 16 & 97 & 40 & 161 \\
\hline \multicolumn{6}{|c|}{ Weekend Sample Size by Time } \\
\hline Area & 6-10 am & 10 am-2 pm & 2-6 pm & $6-10 \mathrm{pm}$ & Total \\
\hline Riffle Run & 10 & 20 & 121 & 51 & 202 \\
\hline Bulltown & 5 & 10 & 59 & 25 & 99 \\
\hline Total & 15 & 30 & 180 & 76 & 301 \\
\hline \multicolumn{5}{|l|}{ Grand Total } & 462 \\
\hline & & & & & (Sheet \\
\hline 1 Sample Size - 462 & & & & & \\
\hline
\end{tabular}




\section{Table B1 (Continued)}

\begin{tabular}{|c|c|c|c|c|c|}
\hline \multicolumn{6}{|c|}{ Canyon Lake Day-Use Sample' } \\
\hline \multirow[b]{2}{*}{ Area } & \multirow[b]{2}{*}{ \# Vehicles } & \multirow[b]{2}{*}{$\%$ of Total } & \multicolumn{3}{|c|}{ Sample Size } \\
\hline & & & Area Total & Weekday & Weekend \\
\hline Comal Park & 22,417 & 30 & 139 & 11 & 128 \\
\hline Canyon Park & 51,453 & 70 & 323 & 26 & 297 \\
\hline Total & 73,870 & 100 & 462 & 37 & 425 \\
\hline \multicolumn{6}{|c|}{ Weekday Sample Size by Time } \\
\hline Area & 6-10 am & $10 \mathrm{am}-2 \mathrm{pm}$ & 2-6 pm & 6-10 pm & Total \\
\hline Comal Park & 1 & 2 & 3 & 5 & 11 \\
\hline Canyon Park & 1 & 5 & 8 & 12 & 26 \\
\hline Total & 2 & 7 & 11 & 17 & 37 \\
\hline \multicolumn{6}{|c|}{ Weekend Sample Size by Time } \\
\hline Area & 6-10 am & $10 \mathrm{am}-2 \mathrm{pm}$ & 2-6 pm & 6-10 pm & Total \\
\hline Comal Park & 6 & 26 & 38 & 58 & 128 \\
\hline Canyon Park & 15 & 59 & 89 & 134 & 297 \\
\hline Total & 21 & 85 & 127 & 192 & 425 \\
\hline \multicolumn{5}{|l|}{ Grand Total } & 462 \\
\hline \multicolumn{6}{|c|}{ Truman Lake Day-Use Sample ${ }^{1}$} \\
\hline \multirow[b]{2}{*}{ Area } & \multirow[b]{2}{*}{ \# Vehicles } & \multirow[b]{2}{*}{$\%$ of Total } & \multicolumn{3}{|c|}{ Sample Size } \\
\hline & & & Area Total & Weekday & Weekend \\
\hline Long Shoal & 7,534 & 42 & 194 & 103 & 91 \\
\hline Shawnee Bend & 10,606 & 58 & 268 & 169 & 99 \\
\hline Total & 18,140 & 100 & 462 & 272 & 190 \\
\hline \multicolumn{6}{|c|}{ Weekday Sample Size by Time } \\
\hline Area & 6-10 am & $10 \mathrm{am}-2 \mathrm{pm}$ & 2-6 pm & 6-10 pm & Total \\
\hline Long Shoal & 5 & 31 & 52 & 15 & 103 \\
\hline Shawnee Bend & 8 & 51 & 85 & 25 & 169 \\
\hline Total & 13 & 82 & 137 & 40 & 272 \\
\hline \multicolumn{6}{|c|}{ Weekend Sample Size by Time } \\
\hline Area & $6-10 \mathrm{am}$ & 10 am-2 pm & $2-6 \mathrm{pm}$ & 6-10 pm & Total \\
\hline Long Shoal & 5 & 27 & 46 & 14 & 92 \\
\hline Shawnee Bend & 5 & 30 & 50 & 15 & 100 \\
\hline Total & 10 & 57 & 96 & 29 & 192 \\
\hline \multicolumn{5}{|l|}{ Grand Total } & 464 \\
\hline & & & & & (Sheet 2 \\
\hline 1 Sample Size - 462 & & & & & \\
\hline
\end{tabular}




\section{Table B1 (Concluded)}

\begin{tabular}{|c|c|c|c|c|c|}
\hline \multicolumn{6}{|c|}{ J. Percy Priest Lake Day-Use Sample ${ }^{1}$} \\
\hline \multirow[b]{2}{*}{ Area } & \multirow[b]{2}{*}{ \# Vehicles } & \multirow[b]{2}{*}{$\%$ of Total } & \multicolumn{3}{|c|}{ Sample Size } \\
\hline & & & Area Total & Weekday & Weekend \\
\hline Anderson Road & 23,470 & 66 & 305 & 122 & 183 \\
\hline Cook Rec. Area & 11,932 & 34 & 157 & 63 & 94 \\
\hline Total & 35,402 & 100 & 462 & 185 & 277 \\
\hline \multicolumn{6}{|c|}{ Weekday Sample Size by Time } \\
\hline Area & 6-10 am & $10 \mathrm{arn}-2 \mathrm{pm}$ & $2-6 \mathrm{pm}$ & 6-10 pm & Total \\
\hline Anderson Road & 6 & 24 & 73 & 18 & 121 \\
\hline Cook Rec. Area & 3 & 13 & 38 & 9 & 63 \\
\hline Total & 9 & 37 & 111 & 27 & 184 \\
\hline \multicolumn{6}{|c|}{ Weekend Sample Size by Time } \\
\hline Area & 6-10 am & $10 \mathrm{am}-2 \mathrm{pm}$ & $2-6 \mathrm{pm}$ & 6-10 pm & Total \\
\hline Anderson Road & 9 & 37 & 110 & 27 & 183 \\
\hline Cook Rec. Area & 5 & 19 & 56 & 14 & 94 \\
\hline Total & 14 & 56 & 166 & 41 & 277 \\
\hline \multicolumn{5}{|l|}{ Grand Total } & 461 \\
\hline \multicolumn{6}{|c|}{ Mendocino Lake Day-Use Sample ${ }^{1}$} \\
\hline \multirow[b]{2}{*}{ Area } & \multirow[b]{2}{*}{ \# Vehicies } & \multirow[b]{2}{*}{$\%$ of Total } & \multicolumn{3}{|c|}{ Sample Size } \\
\hline & & & Area Total & Weekday & Weekend \\
\hline Pomo & 16988 & 42 & 194 & 103 & 91 \\
\hline Che-ka-ka & 23,320 & 58 & 268 & 142 & 126 \\
\hline Total & 40,308 & 100 & 462 & 245 & 217 \\
\hline \multicolumn{6}{|c|}{ Weekday Sample Size by Time } \\
\hline Area & 6-10 am & $10 \mathrm{am}-2 \mathrm{pm}$ & $2-6 \mathrm{pm}$ & 6-10 pm & Total \\
\hline Pomo & 10 & 21 & 41 & 31 & 103 \\
\hline Che-ka-ka & 14 & 28 & 57 & 43 & 142 \\
\hline Total & 24 & 49 & 98 & 74 & 245 \\
\hline \multicolumn{6}{|c|}{ Weekend Sample Size by Time } \\
\hline Area & 6-10 am & $10 \mathrm{am}-2 \mathrm{pm}$ & $2-6 \mathrm{pm}$ & 6-10 pm & Total \\
\hline Pomo & 9 & 18 & 36 & 27 & 90 \\
\hline Che-ka-ka & 13 & 25 & 50 & 38 & 126 \\
\hline Total & 22 & 43 & 86 & 65 & 216 \\
\hline \multicolumn{5}{|l|}{ Grand Total } & 461 \\
\hline & & & & & (Sheet 3 of 3 ) \\
\hline ample Size & & & & & \\
\hline
\end{tabular}




\begin{tabular}{|c|c|c|c|c|c|c|}
\hline & & $\begin{array}{r}\text { Day Use Da } \\
\text { U.S. Arn } \\
\text { ps of Engine }\end{array}$ & $\begin{array}{l}\text { a Collectior } \\
\text { y Corps of En } \\
\text { rs' Project: } \mathrm{E}\end{array}$ & $\begin{array}{l}\text { Schedule } \\
\text { ineers } \\
\text { rnsville Lak }\end{array}$ & & \\
\hline Sunday & Monday & Tuesday & Wednesday & Thursday & Friday & Saturday \\
\hline & & & $\begin{array}{r}\text { June } 9 \\
\text { Orientation }\end{array}$ & $\begin{array}{c}\text { DU2 } \\
\text { Do } \\
10: 00 \\
(5)\end{array}$ & $\begin{array}{cc} & 11 \\
\text { DU1 } & \\
10: 00 & \\
(11) & \end{array}$ & $\begin{array}{l}12 \\
\text { DU1 10:00 } \\
(10) \\
\text { DU2 18:00 } \\
(13) \\
\end{array}$ \\
\hline 13 & 14 & 15 & 16 & 17 & 18 & 19 \\
\hline $\begin{array}{c}\text { DU2 06:00 } \\
(3) \\
\text { DU1 } 14: 00 \\
(61)\end{array}$ & $\begin{array}{l}\text { DU1 } \\
18: 00 \\
(14)\end{array}$ & Day Off & Day Off & $\begin{array}{l}\text { DU2 } \\
06: 00 \\
\text { (3) }\end{array}$ & $\begin{array}{l}\text { DU1 } \\
06: 00 \\
(5)\end{array}$ & $\begin{array}{c}\text { DU2 10:00 } \\
(5) \\
\text { DU1 18:00 } \\
(26) \\
\end{array}$ \\
\hline 20 & 21 & 22 & 23 & 24 & 25 & 26 \\
\hline $\begin{array}{c}\text { DU1 10:00 } \\
(10) \\
\text { DU2 18:00 } \\
(12)\end{array}$ & $\begin{array}{c}\text { DU1 } \\
14: 00 \\
(33)\end{array}$ & Day Off & Day Off & $\begin{array}{l}\text { DU2 } \\
18: 00 \\
(7)\end{array}$ & $\begin{array}{c}\text { DU2 } \\
14: 00 \\
(16)\end{array}$ & $\begin{array}{c}\text { DU2 10:00 } \\
(5) \\
\text { DU1 18:00 } \\
(25) \\
\end{array}$ \\
\hline 27 & 28 & 29 & 30 & July 1 & 2 & 3 \\
\hline $\begin{array}{c}\text { DU1 06:00 } \\
(5) \\
\text { DU2 14:00 } \\
(30)\end{array}$ & $\begin{array}{l}\text { DU2 } \\
18: 00 \\
(6)\end{array}$ & Day Off & Day Off & $\begin{array}{c}\text { DU2 } \\
14: 00 \\
(16)\end{array}$ & $\begin{array}{l}\text { DU1 } \\
18: 00 \\
(13)\end{array}$ & $\begin{array}{c}\text { DU2 06:00 } \\
(2) \\
\text { DU1 14:00 } \\
(60)\end{array}$ \\
\hline 4 & 5 & 6 & 7 & 8 & 9 & 10 \\
\hline $\begin{array}{c}\text { DU1 06:00 } \\
(5) \\
\text { DU2 14:00 } \\
(29) \\
\end{array}$ & $\begin{array}{l}\text { DU1 } \\
14: 00 \\
(32)\end{array}$ & Day Off & Day Off & $\begin{array}{l}\text { Week day } \\
\text { Rain day } 1\end{array}$ & $\begin{array}{l}\text { Week day } \\
\text { Rain day } 2\end{array}$ & $\begin{array}{l}\text { Weekend } \\
\text { Rain day } 1\end{array}$ \\
\hline 11 & 12 & 13 & 14 & & & \\
\hline $\begin{array}{l}\text { Weekend } \\
\text { Rain day } 2\end{array}$ & $\begin{array}{l}\text { Week day } \\
\text { Rain day } 3\end{array}$ & & & & & \\
\hline $\begin{array}{l}\text { Key to Sites: } \\
\text { DU } 1=\text { Day us } \\
\text { DU } 2 \text { = Day us }\end{array}$ & $\begin{array}{l}\text { site \#1 } \\
\text { site \#2 }\end{array}$ & $\frac{\text { Riffle Run }}{\text { Bulltown }}$ & & $\begin{array}{c}\text { Key to Tim } \\
06: 00= \\
10: 00= \\
14: 00= \\
18: 00=\end{array}$ & $\begin{array}{l}\text { s: } \\
\text { a.m. to } 10 \text { a.m. } \\
\text { :00 a.m. to } 2 \text { p.m } \\
\text { p.m. to } 6 \text { p.m. } \\
\text { p.m. to } 10 \text { p.m. }\end{array}$ & \\
\hline Keys to Quotas: & & $(x x)=n u m$ & Der of contacts $n$ & gded & & \\
\hline
\end{tabular}




\section{Table B2 (Continued)}

Day Use Data Collection Schedule

U.S. Army Corps of Engineers

Corps of Engineers' Project: Strom Thurmond Lake

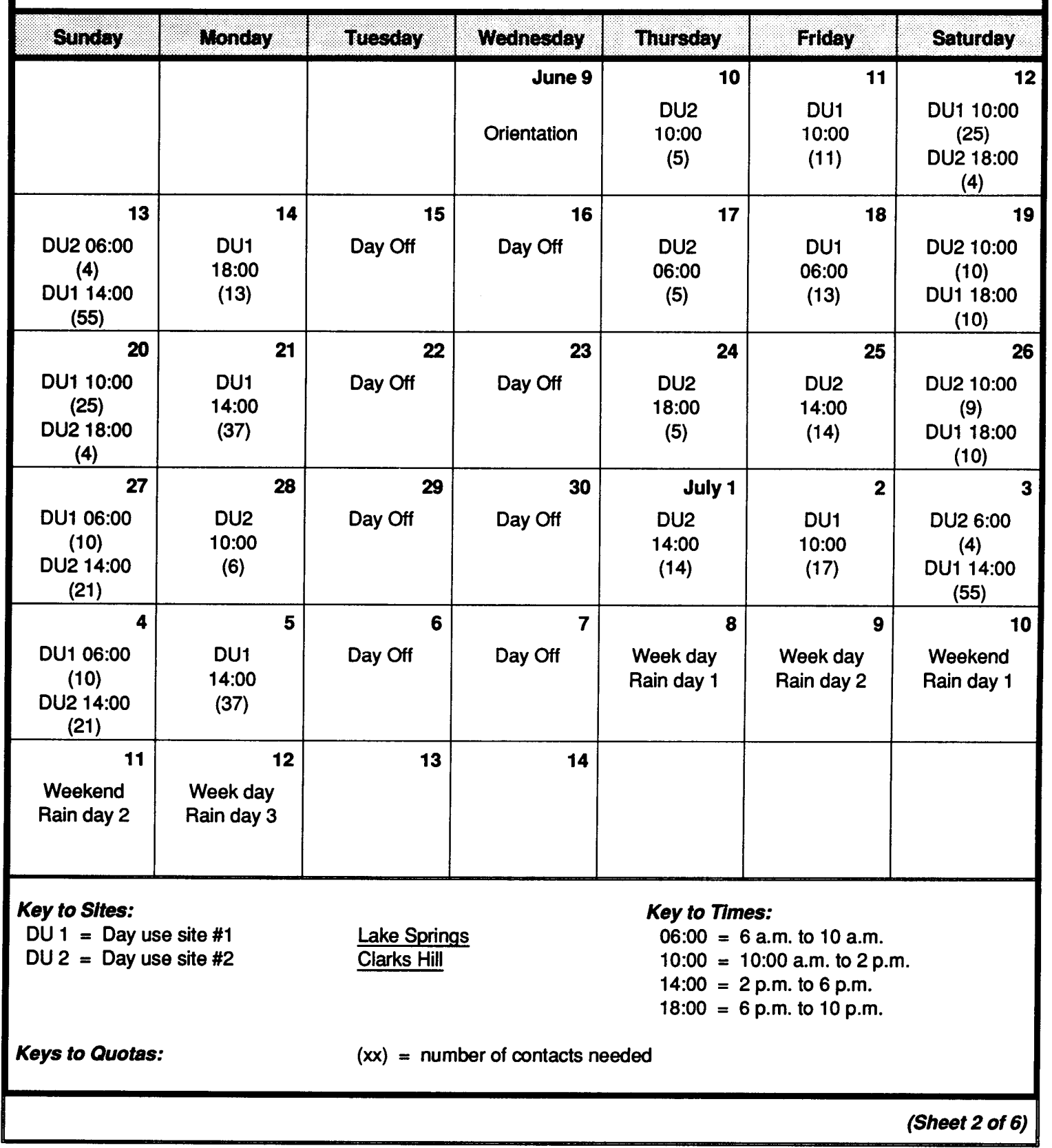




\section{Table B2 (Continued)}

Day Use Data Collection Schedule

U.S. Army Corps of Engineers

Corps of Engineers' Project: $\underline{\text { J. Percy Priest Lake }}$

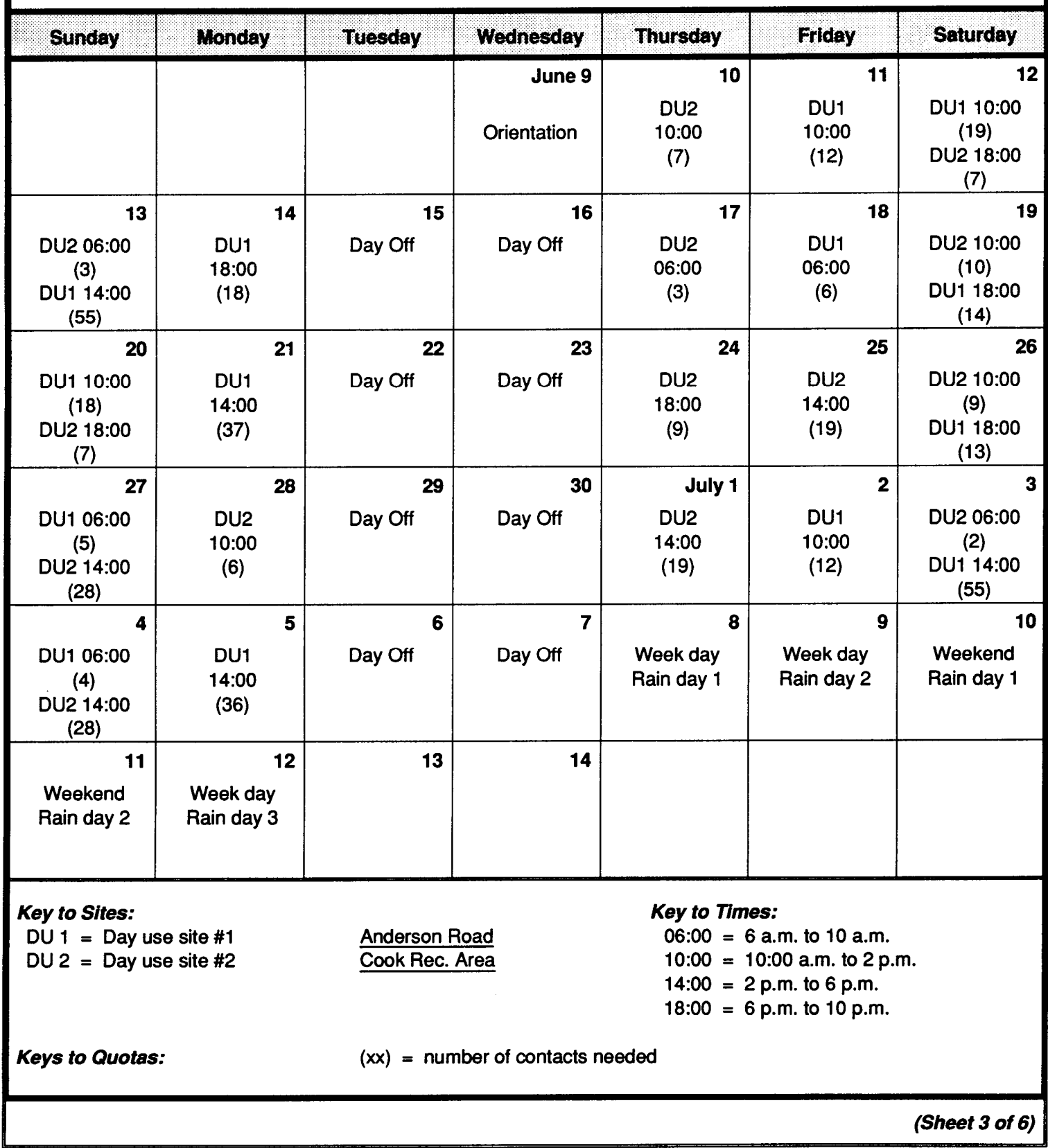




\begin{tabular}{|c|c|c|c|c|c|c|}
\hline & & $\begin{array}{l}\text { Day Use Da } \\
\text { U.S. Arn } \\
\text { orps of Engin }\end{array}$ & $\begin{array}{l}\text { a Collectiol } \\
\text { y Corps of En } \\
\text { ers' Project: }\end{array}$ & $\begin{array}{l}\text { Schedule } \\
\text { ineers } \\
\text { Iruman Lake }\end{array}$ & & \\
\hline Sunday & Monday & Tuesday & Wednesday & Thursday & Friday & Saturday. \\
\hline & & & $\begin{array}{r}\text { June } 9 \\
\text { Orientation }\end{array}$ & \begin{tabular}{cc|} 
DU2 & \\
$10: 00$ & 10 \\
$(26)$ &
\end{tabular} & $\begin{array}{c}{ }^{11} \\
\text { DU1 } \\
10: 00 \\
(16)\end{array}$ & $\begin{array}{l}12 \\
\text { DU1 10:00 } \\
(14) \\
\text { DU2 18:00 } \\
(8) \\
\end{array}$ \\
\hline 13 & 14 & 15 & 16 & 17 & 18 & 19 \\
\hline $\begin{array}{c}\text { DU2 06:00 } \\
(3) \\
\text { DU1 14:00 } \\
(23) \\
\end{array}$ & $\begin{array}{l}\text { DU1 } \\
18: 00 \\
(15)\end{array}$ & Day Off & Day Off & $\begin{array}{c}\text { DU2 } \\
06: 00 \\
(8)\end{array}$ & $\begin{array}{l}\text { DU1 } \\
06: 00 \\
(5)\end{array}$ & $\begin{array}{l}\text { DU2 10:00 } \\
(15) \\
\text { DU1 18:00 } \\
(7) \\
\end{array}$ \\
\hline 20 & 21 & 22 & 23 & 24 & 25 & 26 \\
\hline $\begin{array}{c}\text { DU1 10:00 } \\
(13) \\
\text { DU2 18:00 } \\
(7) \\
\end{array}$ & $\begin{array}{l}\text { DU1 } \\
14: 00 \\
(26)\end{array}$ & Day Off & Day Off & $\begin{array}{c}\text { DU2 } \\
18: 00 \\
(25)\end{array}$ & $\begin{array}{c}\text { DU2 } \\
14: 00 \\
(43)\end{array}$ & $\begin{array}{l}\text { DU2 10:00 } \\
(15) \\
\text { DU1 18:00 } \\
(7) \\
\end{array}$ \\
\hline 27 & 28 & 29 & 30 & July 1 & 2 & 3 \\
\hline $\begin{array}{l}\text { DU1 06:00 } \\
(3) \\
\text { DU2 14:00 } \\
(25) \\
\end{array}$ & $\begin{array}{l}\text { DU2 } \\
10: 00 \\
(25)\end{array}$ & Day Off & Day Off & $\begin{array}{c}\text { DU2 } \\
14: 00 \\
(42)\end{array}$ & $\begin{array}{l}\text { DU1 } \\
10: 00 \\
(15)\end{array}$ & $\begin{array}{l}\text { DU2 06:00 } \\
\quad(2) \\
\text { DU1 14:00 } \\
(23) \\
\end{array}$ \\
\hline 4 & 5 & 6 & 7 & 8 & 9 & 10 \\
\hline $\begin{array}{l}\text { DU1 06:00 } \\
(2) \\
\text { DU2 14:00 } \\
(25) \\
\end{array}$ & $\begin{array}{c}\text { DU1 } \\
14: 00 \\
(26)\end{array}$ & Day Off & Day Off & $\begin{array}{l}\text { Week day } \\
\text { Rain day } 1\end{array}$ & $\begin{array}{l}\text { Week day } \\
\text { Rain day } 2\end{array}$ & $\begin{array}{l}\text { Weekend } \\
\text { Rain day } 1\end{array}$ \\
\hline $\begin{array}{l}\text { Weekend } \\
\text { Rain day } 2\end{array}$ & $\begin{array}{l}\text { Week day } \\
\text { Rain day } 3\end{array}$ & 13 & 14 & & & \\
\hline \multicolumn{2}{|c|}{$\begin{array}{l}\text { Key to Sites: } \\
\text { DU } 1 \text { = Day use site \#1 } \\
\text { DU } 2 \text { = Day use site \#2 }\end{array}$} & \multirow{2}{*}{\multicolumn{5}{|c|}{$\begin{array}{l}\text { Key to Times: } \\
\begin{aligned} 06: 00 & =6 \text { a.m. to } 10 \text { a.m. } \\
10: 00 & =10: 00 \text { a.m. to } 2 \text { p.m. } \\
14: 00 & =2 \text { p.m. to } 6 \text { p.m. } \\
18: 00 & =6 \text { p.m. to } 10 \text { p.m. }\end{aligned}\end{array}$}} \\
\hline \multicolumn{2}{|l|}{ Keys to Quotas: } & & & & & \\
\hline \multicolumn{7}{|r|}{ (Sheet 4 of 6 ) } \\
\hline
\end{tabular}




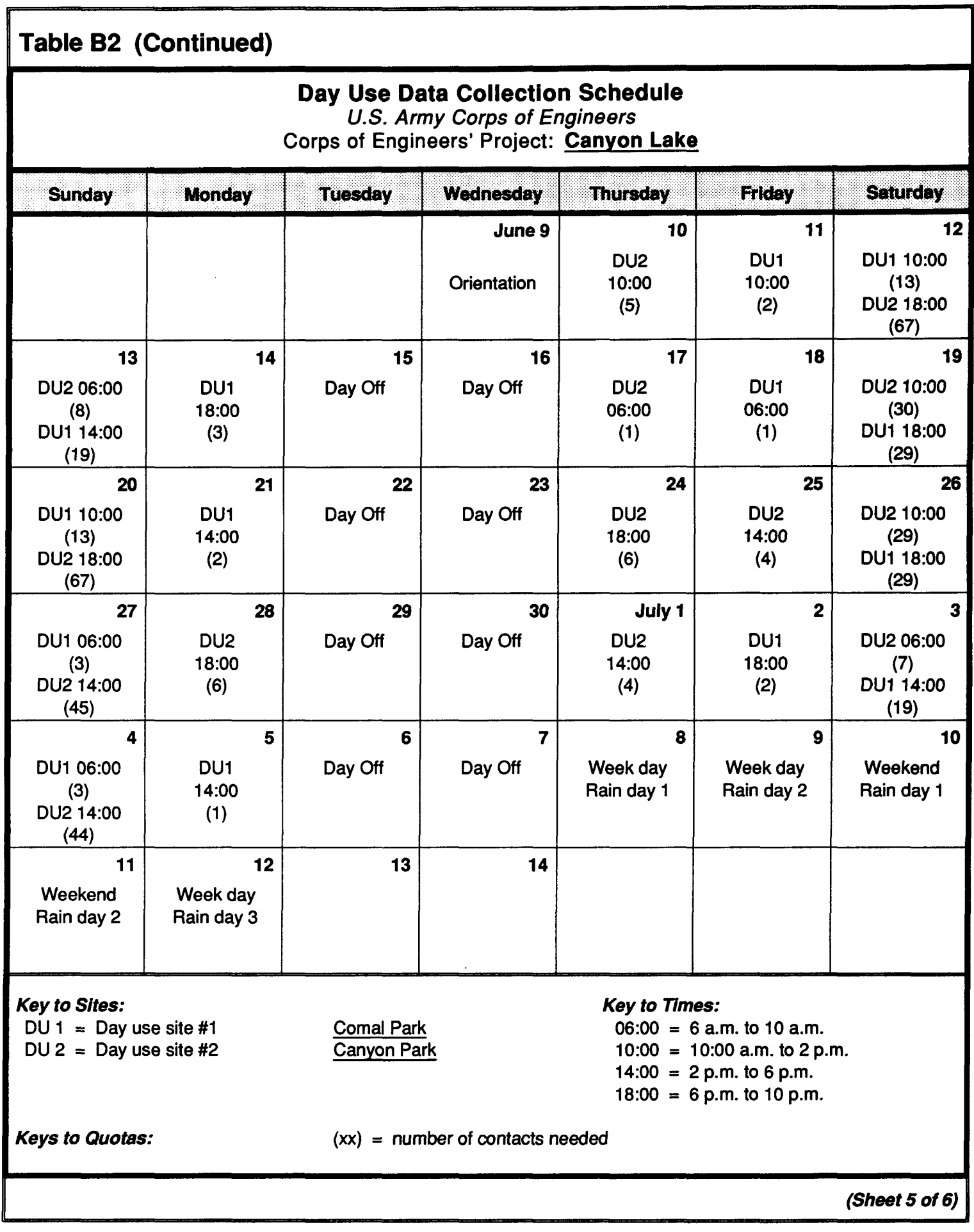




\section{Table B2 (Concluded)}

Day Use Data Collection Schedule

U.S. Army Corps of Engineers

Corps of Engineers' Project: Mendocino Lake

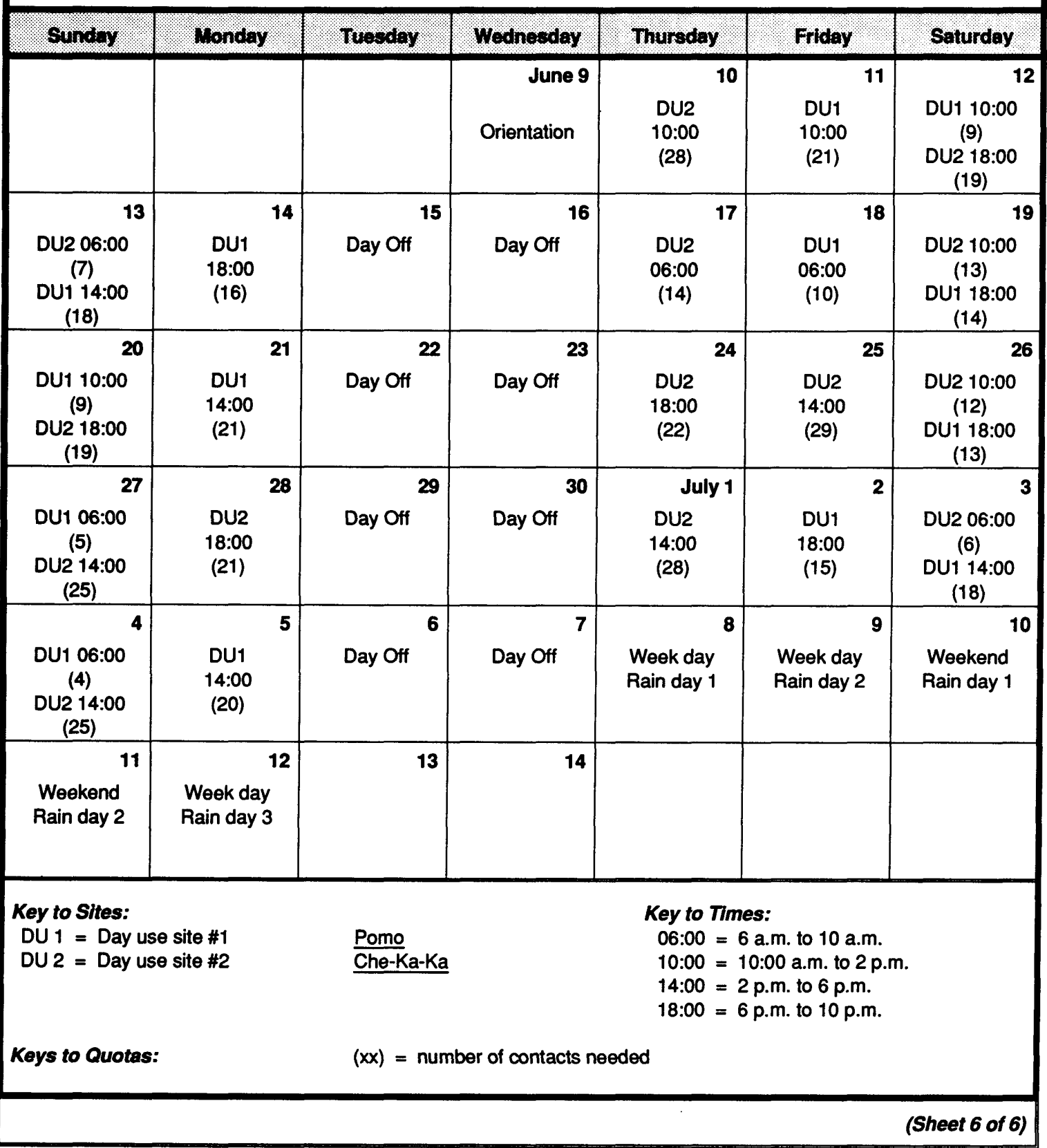




\section{Table B3}

Day-Use Visitor's Information Sheet

OMB \#: 0710-0001

Exp: 11/30/95

\section{Day-Use Visitors - Information About Your Visit}

Are you camping at a Corps campground at this lake this trip? Yes No

Day of Week:

Date of Visit:

Time your vehicle was stopped: $\mathrm{am} / \mathrm{pm}$

Lake Visited:

Day-use area visited:

Number of people in party:

Number of hours spent at day-use area:

Primary activity during visit:

Name:

Mailing address: 


\begin{tabular}{|c|c|c|c|}
\hline \multicolumn{4}{|c|}{$\begin{array}{l}\text { Table B4 } \\
\text { Probit Equation for “Neither Fee” Respondents Used } \\
\text { to Estimate Consumer's Surplus }\end{array}$} \\
\hline Variable & Coefficient & Standard Error & t-ratio \\
\hline Constant & 0.147 & 0.504 & 0.29 \\
\hline ADDCOST & $-0.024^{*}$ & 0.005 & -4.93 \\
\hline INCOME & -0.003 & 0.005 & -0.56 \\
\hline DISTANCE & $0.017^{*}$ & 0.005 & 3.53 \\
\hline LAKE 1 & 0.477 & 0.404 & 1.18 \\
\hline LAKE 2 & 0.656 & 0.438 & 1.50 \\
\hline LAKE 3 & 0.263 & 0.427 & 0.62 \\
\hline LAKE 4 & 0.180 & 0.451 & 0.40 \\
\hline LAKE 5 & -0.334 & 0.514 & -0.65 \\
\hline QLTY & -0.062 & 0.251 & -0.25 \\
\hline PREFER & -0.168 & 0.243 & -0.69 \\
\hline PAIDFEE & 0.454 & 0.367 & 1.24 \\
\hline BOAT & 0.019 & 0.294 & 0.065 \\
\hline RACE & $-0.770^{*}$ & 0.389 & -1.98 \\
\hline
\end{tabular}

\section{Table B5 \\ Calculation of Expansion Factors for Corps Day-Use Study (by project)}

\begin{tabular}{|l|l|l|l||}
\hline Project & $\begin{array}{l}\text { Number of Visits } \\
\text { Made by Sample }\end{array}$ & $\begin{array}{l}\text { 1992 Total Visits } \\
\text { (\# Vehicles) }\end{array}$ & Expansion Factor \\
\hline Burnsville & 3,443 & 110,647 & 32.14 \\
\hline Strom Thurmond & 2,852 & 169,172 & 59.32 \\
\hline J. Percy Priest & 3,992 & 443,199 & 111.02 \\
\hline Truman & 2,916 & 614,217 & 210.64 \\
\hline Canyon & 1,812 & 501,581 & 276.81 \\
\hline Mendocino & 7,317 & 196,525 & 26.86 \\
\hline 1 Expansion Factor $=1992$ total visits/number of visits made by sample. \\
\hline
\end{tabular}




\section{Appendix C Day-Use Survey Comments}




\section{Burnsville Lake}

Date \# Comment

$7 / 9 \quad 1076 \quad 1$. If costs to come here increased by $\$ 5$, we would not come here as often because the Ohio River is the same distance away, has better fishing, and no entrance fees.

2. If fees were charged, I would fish here less often, I would also fish at Stonewall Jackson less often (Stonewall Jackson is closer to my home than the place I was stopped today).

3. If I have to pay fees, I would like to see where they are being used. But keep in mind that there are a lot of people that would not be able to fish if fees were charged, they could not afford it.

4. Currently, Boat Ramp Package Two is in effect, with the exception of the cleaning station. I think the Engineers should pay for the package and for the facility to be upgraded.

7/20 1086 Our tax money paid to create and maintain these day use areas, therefore we should not be charged.

7/21 1142 Fees should not be charged at these day-use areas, "I grew up there, and I wouldn't pay a penny. They run us out of there and I don't see why we have to pay to see my home land. I am a riffle."

1189 The restrooms were closed the entire time of our visit.

1023 We use this area for swimming. "We usually use Burnsville Lake at site of $\mathrm{dam} /$ there is no swimming area which creates a problem for us! We otherwise have to travel 18 miles to Bulltown which isn't fair to Burnsville residents since our family gave up a lot of land for this project!."

7/26 1038 I would be interested in a vehicle annual pass for ALL state day use areas or/and annual pass for all United States day use areas.

$7 / 27 \quad 1375$ 1. You need a swimming beach.

2. At the Riffle Run area, there are always swimmers in the boat launch area. You need security in this area to keep the swimmers away, it is very dangerous.

3. Security is good at all other areas except Riffle Run.

1017 We need a beach area at the Burnsville Dam.

1304 "Would like to have the lake left up from October to December so we can use boat during hunting season at Bulltown camping area."

"We have no beach at Burnsville, but we would like to have one."

7/29 1332 We like to come here, we also like to go to Sulton Lake, Bee Run.

$7 / 30 \quad 1140 \quad 1$. I would be willing to pay money here if you put a beach in, you really need one here for kids to swim.

2. I come here every day to take my kids to the playground.

$8 / 21228$ 1. It is important to have some picnic tables in shade near the water.

2. If you charge a fee, keep it low, because of the large amount of people in the area that would not be able to afford it. 
1149 "It is ridiculous amounts of money appropriated to do stupid studies like this one that is causing the decline and fall of this great country."

1155 Rental fees and sales supplies should be enough revenue as to not have to charge fees.

1370 You need a swimming beach.

$8 / 3 \quad 12671$. We come to the lake a lot, mostly to fish and boat.

2. The people who live here should not have to pay, they took their land to build these dams, isn't that enough.

1356 No person, young or old, should have to pay a fee to use these areas, since all our taxes pay for this area.

1180 If we had to pay to come here, we would not come because we do not have a lot of money and there are a lot of places we could swim around here that are free.

1147 1. Security should keep swimmers off the boat ramp.

2. You should charge everyone in the recreational area, not only those using the boating facilities.

1336 1. If fees are charged we will go to Ohio and other states.

2. Fees should not be charged for Corps land. This is why we pay high taxes, fishing licenses, taxes and licenses on boats and trailers.

1041 I should not have to pay to enter the day use area because I spend enough money on gas getting here (I have to drive 100 miles).

1237 There is no swimming beach here.

1172 1. You need a lifeguard.

2. No fees need to be charged, that is what our taxes are for.

1344 1. We came here to meet my brother and his family at the dam.

2. You need a place for swimmers (especially with small children) to walk down to the water, that is not covered with big rocks.

3. The Burnsville lake does not have: a beach, a fish cleaning station, a bicycle path, hiking/walking trails, or interpretive/nature trails.

4. If I can afford the fee, I will come as often as I can, if I can not afford it, I would not come as often.

Hot showers would be great to have here.

8/5 1360 If you charge a fee we will not attend. We live in a rural area where salaries are low and money is very limited.

1333 You need a beach at Riffle Run/Burnsville area.

8/9 1186 We do not usually come to Bulltown, we usually go to Sutton Lake.

8/13 1274 We have visited other day use areas on lakes where fees were charged, but it only cost $\$ 1$.

8/17 1080 You need life guards at the beach.

8/24 1182 We come here for family get togethers.

1175 Thank you. Good luck with your survey.

$8 / 2512841$. We like to picnic at the swimming hole.

2. Bec Run is closer to home, but we like BullTown.

3. Clean up the water.

4. Charging money for the public to use public beach and picnic areas is discriminating against low income families.

5. "Over in Clermont Co. Ohio at East Fork Lake they have a large concession stand with restrooms and hot showers and dressing rooms. I believe these food stands can create enough money to do what ever." 
6. "A small dock fee for all boats would not be too bad. After all their the ones who put the gas and oil in the lakes and it would be nice to have it cleaned up once in a while."

1131 I feed the fish at the boat docks.

8/30 1137 "You should get the rocks out from around the Lake at Burnsville so people can actually swim without breaking their legs on those huge rocks.

9/9 1396 Money collected should go to the department of fish and game.

1341 1. This area was a very nice place to stop on my ride for a quick swim.

2. If someone is staying all day, a fee is alright, but if you are just staying for an hour or two, you should not have to pay.

1291 An annual pass is a good idea, I enjoy visiting different areas.

1321 You should build a swimming beach here.

1222 If you are just driving through an area, you should not have to pay a fee.

\section{Strom Thurmond}

\section{Date}

\section{Comment}

$7 / 9 \quad 2087$ If we should pay fees, then we should be allowed to drink alcoholic beverages (not referring to kids getting drunk).

2033 "Charles Hill (Lake Springs Area) is a great place! Keep up the good work!"

2108 "The lock and dam in Augusta, GA is at the Savannah River but its run by the city of Augusta, the core (sic) never charged and when they turned it over to the city they started charging."

2086 1. "If you are going to have people at gates, they should be friendly, Modoc sucks." "Fire the gate attendant."

2. You don't need security patrols in area's like this, "that's what guns are for!"

3. If fees were charged here, I would go to Lake Murray.

4. We should not be charged fees here because the area is not taken care of at all. If you can not take care of this area and the campgrounds, give them to some one who can.

7/15 2069 1. Picnic tables should be shaded.

2. "Auto burglaries are common at boat ramps during non-peak hours. I have not yet experienced this, however, I see broken glass from break in frequently."

3. I come here primarily to fish.

4. If fees were charged, I would find somewhere else to fish.

5. Security patrols should make rounds frequently through the boat ramp areas (because of the frequent car break ins).

$7 / 232324$ I ride my bike into the park.

2258 They used to charge a fee/per vehicle at this area last year and in previous years.

7/26 2136 You should use money collected to make all the areas the same, this would take the pressure off the better areas.

2307 You should allow pets into these areas. Dogs like to swim too.

2437 You should not have to pay a lot to get into a Day Use area when you only stay for a few hours. 
$7 / 27 \quad 2447$ 1. Money that is being made from the sale of electricity at the dam should be used to help support the day use areas.

2. "If you make us pay to enjoy and relax, your taking away the enjoyment and relaxation."

2098 We only stopped here because my trailer had a bad wheel and I was fixing it in the parking lot. I ended up leaving it here because I could not fix it.

8/3 2293 I like to take my dogs swimming here.

2047 Money does not bother me, if fee's were charged I would still try to get out here as often as I can, I do not have much free time.

2441 I enjoy watching the sunset here.

2303 1. An annual pass would be good if it could be used at all Corp Day-Use Areas.

2. We like that there are controlled access to day-use areas (gatehouses with attendants). However, many times we like to stay after dark, and the gates close after dark.

$8 / 6 \quad 2410 \quad 1$. The park was full.

2. The sites would be taken by other people most always if there were covered picnic tables with electricity and showers nearby.

$8 / 92089$ 1. We would like this area, if you could bring pets. We came here to train our dog, but were thrown out because to pets are allowed.

8/10 2315 "Note: Higher taxes on fishing equipment, boats, ammunition, guns; license fees, were hiked to take care of these areas, or the question is, where the money went, when, these prices were raised. Sounds like the Corps wants to stick it to the American Public Again and Again."

8/13 2092 We came here to picnic and check out the area.

2381 Your question seven is a trick question. Package two is the same as package one, how else would you collect the money in number one.

9/2 2327 The recreation personnel were rude, so we left.

2090 I feel that our taxes should take care of the fees.

$9 / 92299$ 1. I come here to exercise my dog.

2. It would not be cost effective to have someone collecting fees, it would cost more to employ them then the actual money collected.

2198 Picnic tables should not be electrified due to the high cost of electricity.

2275 Are you Crazy???? - returning money to the treasury, ha.

2120 I enjoy coming here, it is the only area around I can come to, because I am handicapped, and it is handicapped accessible.

\section{J. Percy Priest}

Date $\quad$ Comments

7/16 3035 People should not pay a full day fee if they are only going to be there for an hour, that would not be fair.

$7 / 20 \quad 3078$ Half of the fees charged should be used for state conservation programs, especially, boat ramps, docks, and moorings, which have more of an impact on the environment.

3148 This day use area is a great place for my daily walks. 
3040 Do not hurt the poor people, we have no other free places to bring our families.

3139 Luxury taxes on bait and tackle as well as government taxes should be used to support these areas.

3251 I have no problem with paying to enter as long as the area is kept safe and there is no drugs and alcohol present (especially on the beach areas).

7/21 3320 "Citizens should not be denied free access to the lake."

3366 The "only thing lacking excellent" at this day-use area "is the dirty bathrooms."

3014 1. The bathrooms here are exceptionally poor.

2. You should use people who owe the courts for community service to help fix up the area.

$7 / 22 \quad 3330 \quad 1$. The playgrounds are in good condition, but are too small.

2. Since I live only two miles away from the lake, my property taxes should be used to maintain the neighborhood, including this day use area.

$7 / 26 \quad 3030 \quad 1$. One of the reasons we moved to a house near the lake was because of the FREE access to the ramps and picnic areas (therefore they do not approve of charging fees).

2. Fees are for county clubs and time sharing areas.

3288 Money collected should be used for the public schools, they really need it.

3230 Senior citizens, like us, living on social security can not afford to pay fees to go to day use areas.

$7 / 27 \quad 3442$ 1. Regardless of the "no dogs" sign, there are always dogs on the beach. Security is not doing a good job of keeping dogs off the beach.

2. I fish at other places around the lake, not at the day-use recreation area.

3008 Some of the money spent at the day-use areas should go to help control drinking beer, this happens at lot at our location.

3135 1. Paying to come here would not be fair, it would be paying twice, once with taxes.

2. If you charged money, how could you keep track of the people coming in on the lake trails, that's how we get here.

3. Most people around here are poor and could not afford to come here anymore if there was a fee.

4. It is nice to come here at night for a walk down to the lake.

5. It is nice that you finally fixed up the Anderson Road area, in the past it was not given any attention, finally its a beautiful open, clean place to go.

2165 It is very important to have shade trees over the picnic tables.

3081 Money collected should be used for security service for single people who wish to walk the fitness trail alone. This is what I do.

$7 / 30 \quad 3309 \quad 1$. You need a bigger parking area by the swimming area.

2. If you charged here we would not come.

3. "The core (sic) used to own where Hermitage Landing is and we used to go there until they sold the land to Baltz Brothers who now charge for their area. It has not made money." We go further now in miles but we do so because it is free, and because we only use the area in the three summer months.

$8 / 2 \quad 3190 \quad 1$. If you charged money, the number of teenagers and young adults visiting would decrease.

2. My friends and I enjoy going down to the beach to sunbathe, fish, and etc.

$8 / 3 \quad 3097$ I will not pay to swim in a lake when there are so many pools around. 
8/10 $3114 \quad$ Playgrounds are very important.

3411 Do not charge fees, we pay enough taxes.

8/13 $3032 \quad$ Playgrounds are important to keep up.

3365 Forty dollars is too much to charge, just to come here for the day.

8/21 3332 The controlled gates have to be closed at night.

$8 / 24 \quad 3276 \quad$ I came here for a boy scout meeting.

3196 I come here for night fishing, the parking lots should be better lighted to deter theft of vehicle or trailers.

$8 / 253268$ 1. I was looking for some of my friends who were fishing at four corners boat dock.

2. I am not in as good health as I used to be, after a lung operation.

3243 The money collected should be used to pad a politician's pocket because the Corps of Engineers is already being backed by taxpayers.

9/3 3238 Picnic Package One and three are good ideas, but number two is bad, you do not need controlled access (a gate house with attendant).

9/8 $3387 \quad$ Public parks are for the public, they should not charge money, even if they are not getting that many funds from the government.

9/9 3204 We had our son's birthday party here today.

3225 1. Do not charge fees.

2. We pay too much money in federal, state, and sales taxes, we should not have to pay to come here.

3. Develop the area around the lake for residential use and use this money to support the park.

\section{Truman}

\section{Date \#}

\section{Comments}

$7 / 234351$ 1. We enjoy staying at the lake cabin.

2. We would pay for camping if there were nice shower houses available.

3. Funds should be used to help keep the areas clean and for better security patrols.

4135 "If the Corps cannot manage with the tax money received, then they should improve or change their management. The Corps receives enough money. They need to be better stewards with what they have. Check the inefficiency in their operation."

4116 1. Recreational use is not on the top of Corps priorities.

2. Fees should not be charged since we have already paid to use these areas with federal and state taxes.

7/26 4006 I live off of my social security checks and would not be able to afford a fee if one were charged.

7/27 4342 The only person we saw working here was the person doing the survey.

4408 1. All Corps of Engineers parks are great, we have been to all of them in the state of MO. Job well done.

2. "By charging a fee aren't you making this like a private club - for only the people who can afford it?"

3. We enjoy having breakfast at Long Shoal Marina.

4353 We came here from out of state and enjoyed it so much, we plan to come back. 
4410 "You folks are crazy if you think you will pull a crowd for K.C. to fish at Truman when you bandits start charging."

4290 It is very unfair to charge us to use this area as my tax dollars paid for this facility to begin with, why should I pay for something I already own.

4075 The rest rooms are really dirty.

4456 We came here to clean our boat.

4039 1. We will not pay to picnic.

2. Only non residents should pay.

"It is wrong to have revenue for something we have already paid for."

"I was informed by a Corp employee last year, "Truman Lake was not constructed for YOU DAMNED fisherman, it is for flood control."

4042 "The people purchased and paid for the lake and pay taxes for the upkeep, why should they pay a fee."

$7 / 304267$ 1. Security patrols and controlled access are very important because of the high crime. Even though the cost of security is high, law enforcement with two way radios are important for safety and medical reasons and makes one more easy in their feeling of safety.

2. The swim beach water was dirty and the lake bottom was very rocky at Long Shore.

3. Yearly passes are much better than having to get one every time you go to an area.

4. On Truman, we usually camp at the Buck Saw area and then travel to other areas, mostly to swim.

5. We believe people that use an area should pay a fee, those that do not should not be allowed to use the area.

4358 Tax payers should be able to use all areas paid for with their tax money. The questions you ask are misleading, we do not want any new taxes.

4102 We come here for four main reasons: Basketball, visit dam facility local historical areas, visit local points of interest, and to eat at the marina.

4337 1. The activities most important to us are picnicking, fishing, and swimming. 2. If you collect money, do not spread out the spending in too many places. Spreading things out thinly ends up in no one seeing the benefits of the money collected.

4143 We came here to check the flood water level.

$8 / 3 \quad 4017$ Do not charge fees, we pay taxes.

4331 Fees collected should be used to build an equal rights day use area and any fees should be used to help homeless people get back on their feet. To preserve wildlife and natural habitat.

4123 We were running a trout line today.

8/6 4459 1. Trout lines and fishing buoy's should be done away with.

2. There are people parking cars at Long Shoal in spots that are designated for car and trailer.

3. If you charged a fee here we would go to Lake of the Ozarks.

4. "We all pay out the ass in taxes. Truman Lake should be free.

8/9 4225 We were visiting our relatives and they showed us this area, we will probably not return for 10 years, or until our next visit.

8/10 4158 Since I am retired, I could not come as often if you charged a fee.

$8 / 234388$ Returning fees collected to the U.S. Treasury is a joke, right?? 
8/30 4200 You charge money for camping to keep poor people from being around. Give the little guy some consideration, if you charge to use the rest room we will not be able to go anywhere anymore.

4077 1. I mostly came here to check out my motor boat.

2. I did not come here that often this year because of the flood.

3. No fees are needed, that is what taxes are for.

4. I really enjoy coming here.

4073 Motorcycling is important to me.

4035 We only stopped here on part of a 5,000 mile cross country trip.

9/9 4396 This is the third survey I have filled out.

4068 Taxes are too high, you should not charge us for the only thing we can afford.

\section{Canyon Lake}

Date \#

Comment

7/9 5021 Dogs should be allowed in the park, I like to go swimming with my dog.

$7 / 15 \quad 5105$ The rest rooms are not working, and the porta potty was terrible.

5108 "I am only interested in boat ramps and fishing."

7/16 5102 The rest rooms and hot showers were being redone, due to the flood.

5265 I came here to see the lake.

$7 / 20 \quad 5114$ We like covered picnic tables.

$7 / 215195$ Since our boat is at the marina and we come here many weekends out of the year, we should not have to pay to use the day use area (since we pay to use the marina area). -- If you pay to use the marina, you should not have to pay for the day use area.

7/27 5043 Texas currently has annual passes that can be used, that is what we use.

5391 Senior citizens should not be charged for day use areas.

5403 Clean up from the flood was supposed to be completed by July the Fourth but was still not finished on the fifth.

5151 We were in the Canyon Lake area today, but we do not usually use day use areas, we usually go camping.

5339 We were looking for good areas to go camping with the Boy Scouts.

5072 If you only come here to use picnic tables, swim, and go fishing, you should not have to a pay a fee.

5095 1. We come to the marina here often, our sailboat is here.

2. We would really like to see more restaurants on the water.

3. The Blue Pelican could use some improvement.

$7 / 295179$ We came here to swim, but the area was of poor quality, so we left to go somewhere else.

5199 You should really get lifeguards here.

$7 / 30 \quad 5122 \quad$ "I would like to see a pier for fishing on the north side of the lake where I was fishing like the one on the south side."

5131 Money collected should be used to maintain and buy more wilderness areas on which no development could take place.

5299 We came here to get a map and find out what there is to do here.

$8 / 253951$. We come here to rock hound. 
2. The Corps does not operate facilities such as this one, close to Houston, TX.

8/3 5363 1. The bathrooms here are disgusting.

2. You need more covered picnic tables by the beach area.

3. We love to camp at Potters Creek.

4. We love it here, but have not been coming back as much because of the disgusting bathrooms.

5057 We should not have to pay fees, we already pay them, our boat is at a commercial marina on a Corps Lake.

5163 An annual pass is a good idea if it can be used at all Corps areas.

5132 1. The general condition of the day use areas at canyon lake is terrible.

2. The restrooms are filthy.

3. The swimming and picnicking areas are full of trash, both during the week and on the weekends.

5152 I would only pay a fee here if you would fix up the picnic tables and have cleaner restrooms, right now both are in very bad conditions.

5161 Since we paid to stay at the campground here, we should not have to pay to use the day-use area.

8/4 5103 The bathrooms here were disgusting and have been this way for over two years. You should tell people that come to camp that the bathrooms are out of order. You should not charge so much money either, if the bathrooms are broken.

8/6 5041 We came here to just drive through and check out the lake and day use area but found the areas to be of very poor quality and will not be coming back.

8/9 5138 Do not modernize, leave the area rustic.

5401 This trip was unexpected.

5333 We only came here for a boat show, we usually do not visit these types of areas.

8/13 5181 1. This was our first visit here, we were just looking around.

2. You should not have picnic tables near the beach.

3. The rest rooms were very dirty.

4. The showers were dirty.

5456 Fees collected should be used to balance the deficit.

5433 1. There were no playgrounds or hot showers or moorings or fish cleaning stations here.

2. We came here to check the wind and water roughness or the lake for boating and fishing.

5237 1. The staff are always friendly here.

2. In Texas, there is plenty things to do for free.

8/23 5189 You need to spend more money on water safety.

5425 1. This was our first visit here, we enjoyed it and will return.

2. You need to put in showers here.

5356 Your grounds need to be kept up better.

$8 / 245368$ We came here for a family reunion.

5049 A season pass is a good idea.

5313 The Texas park and recreation pass should apply to the Corps also.

$8 / 25 \quad 5231$ The beaches were great, but other facilities were not available.

$8 / 315155$ I used my radio controlled sail planes here.

$9 / 25220$ The rest rooms were in bad condition. 
5337 We came here for a boat show.

9/8 $5353 \quad$ We never got out of our car when we were here.

9/9 5342 This park is the best in our area for day use. However, when we go camping we go further away.

5357 On this same day, our son and his friend went to Canyon Day-Use area and it cost $\$ 6$, why a fee for a free area???

5338 Canyon Lake is very overused because it does not charge a fee, because of all the areas around that charge fees, for this reason it should be closed at 10 p.m. or 11 p.m.

\section{Lake Mendocino}

Date \# Comment

$7 / 20 \quad 6059$ You should not have to pay money to go on a picnic.

6054 1. We usually do not come to this particular day use area, we came here today just to feed the ducks.

2. "We used to enjoy going to the "Mesa" day use area. It's very discouraging to go there and see the dry, brown (dead) grass."

6156 The road sounds like a race track and the boat motors are too loud.

6126 The beach is overcrowded, which makes me rather swim along the trail.

$7 / 23 \quad 6321$ "It would be nice to have a friendly staff, but you do not have pleasant personnel - the East end of lake, people at the gate - have the personality of a two headed snake."

6103 1. Fees should be used for the area where the fee was paid. It should be used for maintenance and improvement.

2. Annual passes are good if they are affordable $(\$ 20 /$ year).

$7 / 26 \quad 6168$ 1. Biking the trails cost nothing, if it did cost, I would break the law and find a new way in.

2. You should maintain the picnic areas. You should also improve and expand the biking trails. Biking is a growing popular sport.

6133 Where is the beach here? We could not find it.

$7 / 27 \quad 6182$ Season passes are better than daily passes.

6372 I come here at six a.m. when I get off work to watch the sun come up and unwind.

6403 The swimming beach is very dirty.

6318 1. We spend most of our time at the North end of the Lake.

2. I helped my friend take his boat out of the lake.

3. The elderly should not pay any fees.

4. I never visit here on the weekends.

6014 The money spent should be used "to reimburse local county government for the loss of tax dollars when Lake Mendocino $\mathrm{C}$ of $\mathrm{E}$ property was removed from the tax rolls. Every year more private land is removed for state and federal reserves, parks, etc. $70 \%$ of our county is in public ownership and over half of California is not paying local taxes."

6352 A season pass is a good idea.

6308 I usually come here to go boating, but today I came to go to my jobs annual picnic. 
6375 We take rides to the lake almost every day.

6322 1. Fee's collected should be used to reduce the national debt.

2. Although I can afford I fee, I would resent paying it, because our taxes go directly for the upkeep of these areas.

$7 / 29 \quad 6443$ This is the only day use area we know of.

$8 / 26127$ Picnic tables with electricity and restrooms with hot showers are not necessary for day use areas.

60021 . I usually never see any staff.

2. The only reason I come to the lake is to fly remote controlled planes.

6260 1. I came here for a company party.

2. We caught some really delicious striped bass in the lake.

3 . We did not see any staff.

4. We were located between the south and north ramps.

5. No more fees.

6258 1. I never use the campgrounds here.

2. I only come here to fish.

3. Build more lake/reservoir dams.

8/3 6439 "We pay plenty of taxes, why can't some things be fully tax supported."

6113 The quality of this day use area was the poorest ever.

6332 We bring our children here to feed the ducks.

6036 1. As the lake goes down the beach quality lessens.

2. By introducing a fee, the price would only go up.

3. If Congress would CUT spending FIRST this whole booklet would not be necessary. Right?

6383 1. We came here for a birthday party.

2. Fees collected should be used to improve day use areas within the county.

6256 We have only gone to other day use areas for fishing tournaments.

6099 1. The questions in this survey were very poor, we were never here before, but we would come back.

2. An annual pass for one lake is too restrictive, you should have a pass for many Corps areas.

3. I understand nothing is free. I am willing to pay a reasonable fee to use a clean and patrolled area.

6172 I am against paying any fee. We do not have funds for this recreation.

$8 / 4 \quad 6181 \quad 1$. I do not mind paying fees.

2. Fees going to high might eliminate some lower income people from the lake.

3. I am very concerned regarding reservations being available for the campgrounds. We travel two hours only to be told nothing is available. Very frustrating!

6108 1. I live only a mile away and come here daily to visit with some of my retired friends.

2. "Handicapped people as myself can not use boat dock's for no ramps or ladder available to climb into boats!"

3. The boat ramp is locked and we can not use it anyway.

$8 / 6 \quad 6049$ 1. Clear Lake is less choppy and crowded than this lake, but the water quality is poor and it is one hour away.

2. If fees are to be charged, town or county residents should not have to pay, only out of county residents. 
6364 "The staff is always rude at Mendocino campgrounds!! However, the two doing the survey were very friendly!!"

$8 / 9 \quad 6238$ We are part of a large family that visits here often.

$8 / 106234$ "We were only at the dock for 10 minutes. Dumped off the jet ski and my wife. We meet at the other end of the lake. I can not be charged for that.

6378 1. We went to the Pomo Indian interpretive center. It was very nice.

2. If we were charged $\$ 5$ per car, we would not come.

$8 / 136007$ 1. "I am Pomo Indian. As for Medocino Lake, I feel that I should not have to pay because its one thing to be pushed off my land for a man made lake and another to have to pay to use it."

2. You should spend fees collected to help the wildlife populations.

6179 1. You need more ducks, more ramps and less out of towners.

2. I like to ride my motorcycle here.

6201 We came here for a family reunion picnic barbecue.

6359 "The government takes enough taxes from me, that you should not charge any fees at all at any Corps of Engineers facility."

6056 In reference to fees being charged by the Corps, "They make lots of money during the summer on their campground which are all filled all summer and then in the winter they close half of the lake off so no locals can use it. I do not feel people should have to pay to park and use the lake during the day maybe pay for boat ramps but not parking."

6026 Fees collected should be used for Project Heavens:

1. A series of high tech air gliders. One for each endangered predatory bird.

2. A series of ultra-light high-tech gliders, one for each vulture/recorded in air space.

Series One - With colors and markings of bird (typical representation)

Series Two - Wind dependent super series.

6136 1. I would not be able to come as often if there was a fee, I do not attend many sporting events because of the high admission costs.

2. An annual fee would be good.

3. I only live one mile from here. I walk here many times.

4. I have been sailing on this lake for thirty years.

6309 1. "With all due respect - this survey is a shoddy piece of work which does little service to Maine/Orono's reputation via Sea Grant as a responsible curator of resource management input. Shape it up or ship out!! P.S. It leaves a bad taste in my mouth to fill this out. What does that tell you?" 2. Question B11 is worded especially poorly.

8/23 6167 There is no way you should charge higher fees on weekends and holidays, that is not fair.

6270 1. Picnic tables should be shaded.

2. Do not modernize your day use areas, costs will be raised then.

3. I really like picnic package one, gate attendants are not needed, they are too costly.

$8 / 246299$ I come here to walk and swim my dog.

6295 We were just looking for a place to camp overnight with the family.

$8 / 25 \quad 6093$ I only came here to use the rest rooms.

$8 / 30 \quad 6437$ I pay taxes for this place, you can not charge to come here.

6279 You need lifeguards here. 
9/9 6001 1. We came here for celebrations, it is a community gathering place.

2. Money collected should be kept in the area it is collected, and if you ask where the money should go, you should keep your promise and have it really go where is agreed upon.

3. "It is vital that recreational areas remain ACCESSIBLE to ALL. It is preventive medicine ... people need and physically require, opportunities to discharge their accumulated stress before it turns into disease."

4. If people can not afford the "minimal" fee charged they should have an opportunity to establish "work credits" or community service for the area they - want to visit, and therefore not pay the fee they can not afford.

6259 I would still come here if you charged a fee, but I would not like paying the fee.

9/27 6384 If you charged a fee to get in here, I would park somewhere else and bike in on the bike trail.

\section{Unknown Lakes}

$7 / 207003$ The water at the beach is sometimes full of trash.

8/3 7014 We already pay for this area with our taxes.

7002 We come here to drink beer.

7011 You need a life guard.

7013 We came here to repair our boat at the marina.

7022 1. We never saw any staff here.

2. Let Bill Clinton pay for this stuff.

3. "Any money collected should be returned to individuals. The money you seek is already there. Cut out the stupid wasteful spending, shoot a few congressmen, and you will have all the money you need to fix up all these areas."

8/27 7007 1. Our south parking lot on our lake is a meeting place in the morning for five or more people. People that have heart problems to do things. Since we are retired and medical disability, most of use do not have the money to pay one to five dollars a day to go there.

2. We go to the lake around 280 days a year.

\section{Other Comments}

\section{Burnsville Lake}

Date $\quad$ Comment

7/9 10761.I am a Union Carpenter.

2. I ate food at the marina.

$7 / 14 \quad 1044$ We were having a family reunion today.

$7 / 16 \quad 1087$ I used the recreation area as a place to meet my friend.

7/20 1072 We were checking out the lake to see if it would be a good place for girl scout trips.

$7 / 23 \quad 1230 \quad$ We came here just to look around. 
I usually come here for 2 to 8 hours to fish.

We came here for a birthday party.

We came here to get familiar with the area

1381 We drove two vehicles here, one had two people and one had three.

1061 We came here for a family reunion.

7/29 1066 We only came here for a family reunion.

1332 I like to come here with my dog.

7/30 1288 The men in our group came here to girl watch.

$8 / 21299$ We come here to girl watch.

8/3 1007 We only came here to check things out.

1252 We like camping in our camper, but that is the campground area.

8/9 1273 We do not own a boat.

$8 / 131283$ I come here every Wednesday.

8/23 1114 I came here to visit some campers.

\section{Strom Thurmond Lake}

Date \#

Comment

7/9 2007 I am a Pacific Islander.

2086 I am a white, and it is none of your business what my income is.

2034 I lost my fishing lures today, so I had to buy new ones.

$7 / 152010$ I am only 17, and girl watching is very important to me.

2070 I am a full time student, so I don't really make any money, not enough to come back if fees were charged.

$7 / 20 \quad 2182$ I like to scuba dive and hang glide.

$7 / 212057$ I like to bring my dog here to swim.

$7 / 272165$ This trip was the only one we took to this area of the state.

2115 We enjoy sitting in the porch swing.

2360 Our grandson was injured in the playground and had to go to the emergency room.

7/29 2391 We came here to go camping.

$7 / 302099$ Old fashioned girl watching is what we come here for.

2031 If I had to pay money to come here I would find somewhere else to go where I would not have to pay a fee.

$8 / 2 \quad 2305$ I only stopped here to wash my hands.

8/6 2097 There should not be any surplus money going anywhere except where it was collected.

9/9 2120 I am white, but I have black relatives.

\section{J. Percy Priest Lake}

Date \# Comments

7/20 $3037 \quad$ My company paid for everything on this trip.

$7 / 213142$ 1. I like to go to the beaches and swimming areas with my metal detector.

2. I like to walk around here, this is the area I was "born and raised." 
$7 / 23 \quad 3127$ No fees, the government already takes 5 or 6 months of my total income away, is not that enough? Tell Congress to use better more efficient ways to spend money.

$7 / 26 \quad 3271$ You should not have to pay to swim in a lake.

$7 / 27 \quad 3145$ I like to come here with my dog.

3303 We live in this area.

$8 / 3 \quad 3026$ I came here to visit my family.

$8 / 17 \quad 3076 \quad$ I have an in home licensed day care center.

$9 / 3 \quad 3238 \quad$ I came here looking for girls.

\section{Truman Lake}

Date \# Comment

7/23 4135 I only came here to help put my friends boat in the water.

4116 We launch our boat as close to where we think the best fishing is.

7/26 4080 I am an American and should not have to pay fees because we pay enough taxes already.

4099 We were just checking on out boat at the marina.

4006 1. I like to come to watch the deer play.

2. I have a vacation house five miles from here where my five children come to visit me.

4418 I have a lake home two miles from the day-use area.

7/27 4342 We came almost 1700 miles to visit this area (from California).

7/29 4285 Coming here to be together with our family is very important.

$7 / 30 \quad 4059$ I do not want to pay a fee, I pay taxes and a lot of them.

$8 / 24194$ 1. We ate dinner at the Boat Dock restaurant.

2. We rented a boat slip for the summer.

4373 We did not stay long, it started to thunder and lightning.

4091 I come here many times to get together with friends for lunch.

$8 / 3 \quad 4122$ It was very windy the day we were here.

$8 / 10 \quad 4375$ I come here to hunt.

4190 I do not fish.

$8 / 13 \quad 4140$ We ate a meal at the marina.

4240 Fee's should not be made at day use areas.

4377 I come here to hunt.

8/17 4074 "We put our boat in at a different place and then drove the boat over to the beach because it has no boat ramp."

4060 1. The fishing is not that great on weekends anyway. We never have had very good fishing luck.

2. "I would not trust any government agency with money to use as it see's fit. Take some of the Pork users off and use that money (like the catsup thickness tester).

9/8 4448 We only came here to eat. 


\section{Canyon}

Date

Comments

$7 / 9 \quad 5048 \quad$ I am thinking about buying a boat, then some of my responses would change to these questions.

7/9 $5002 \quad$ Visiting sister and brother in law, that live near here, to help repair their boat.

7/15 5105 I am a descendent of an American Indian.

5027 We rented a boat.

$7 / 20 \quad 5114$ We just moved to Texas.

$7 / 215318$ We were just driving through.

$7 / 265397$ We came here searching for future camping and picnic areas.

5332 We came here because we were visiting the resort next door.

$7 / 275391$ Due to poor health (both being 79 years of age) we come here to fish and relax, bringing our camper like we had in the past is too strenuous.

5003 Money does not matter when you are having fun.

5011 This was a bad survey, there is pages missing????

$7 / 295223$ "There is no S or P in Cor (Corps), learn how to spell. We are poor. We have no home. We found this in the street. Please send us money. We have a cardboard box under the border bridge. Thanks."

$7 / 30 \quad 5036 \quad$ We only came here to see what was here.

5131 I have been coming here for a five week sailing class.

5075 We came here to observe the beautiful members of the female gender.

8/3 $5230 \quad$ 1. I mostly come here to drink beer.

2. I went tubing on the Guadelupe River.

$8 / 5 \quad 5158 \quad 1$. You spelt my name and city wrong.

2. I came here for the day, my husband and son spend the night at the campground.

8/13 5004 We only came here to pull our boat out of the water.

5125 Came here to work on my boat.

5241 We only came here for sightseeing.

$8 / 175436$ I use the marina, not the boat ramp.

5096 "I wasn't that impressed with the day-use area where my car was stopped. If a fee was set at THIS AREA it would have to be cleaned up a lot before I'd pay to go in. I don't mean to be rude - just honest."

5250 I used my cellular phone here, it was very expensive.

8/23 5073 We went to a party at the marina.

5147 I was looking for a good fishing spot.

9/2 $5206 \quad$ I like to scuba dive.

\section{Lake Mendocino}

Date \# Comment

7/16 6176 I am a Hawaiian, and I come here to look at the "Laid"ies.

$7 / 206063$ I came here just to walk around the dam.

6127 We come here to walk our dogs. 
$7 / 26 \quad 6399$ We came here for a family reunion.

6340 We just came here to check on the lake's water conditions.

$7 / 276182$ I came here to visit my son, he lives in this area. I live in Buena Park.

6403 We came here to socialize and play frisbee.

6025 I like to read here.

$8 / 6 \quad 6272$ It is none of your business how much money we make.

6023 If you charge money, I will not come here anymore.

$8 / 136367$ 1. We came here looking for friends to Barbecue with.

2. I come here all summer.

8/24 6091 I came here looking for my uncle.

$8 / 306391$ I come here to drink.

6062 I am not presently employed because I have a disability.

$9 / 9 \quad 6251$ I like to watch boaters come and go.

6254 I am a redneck and we came here for a wedding. 


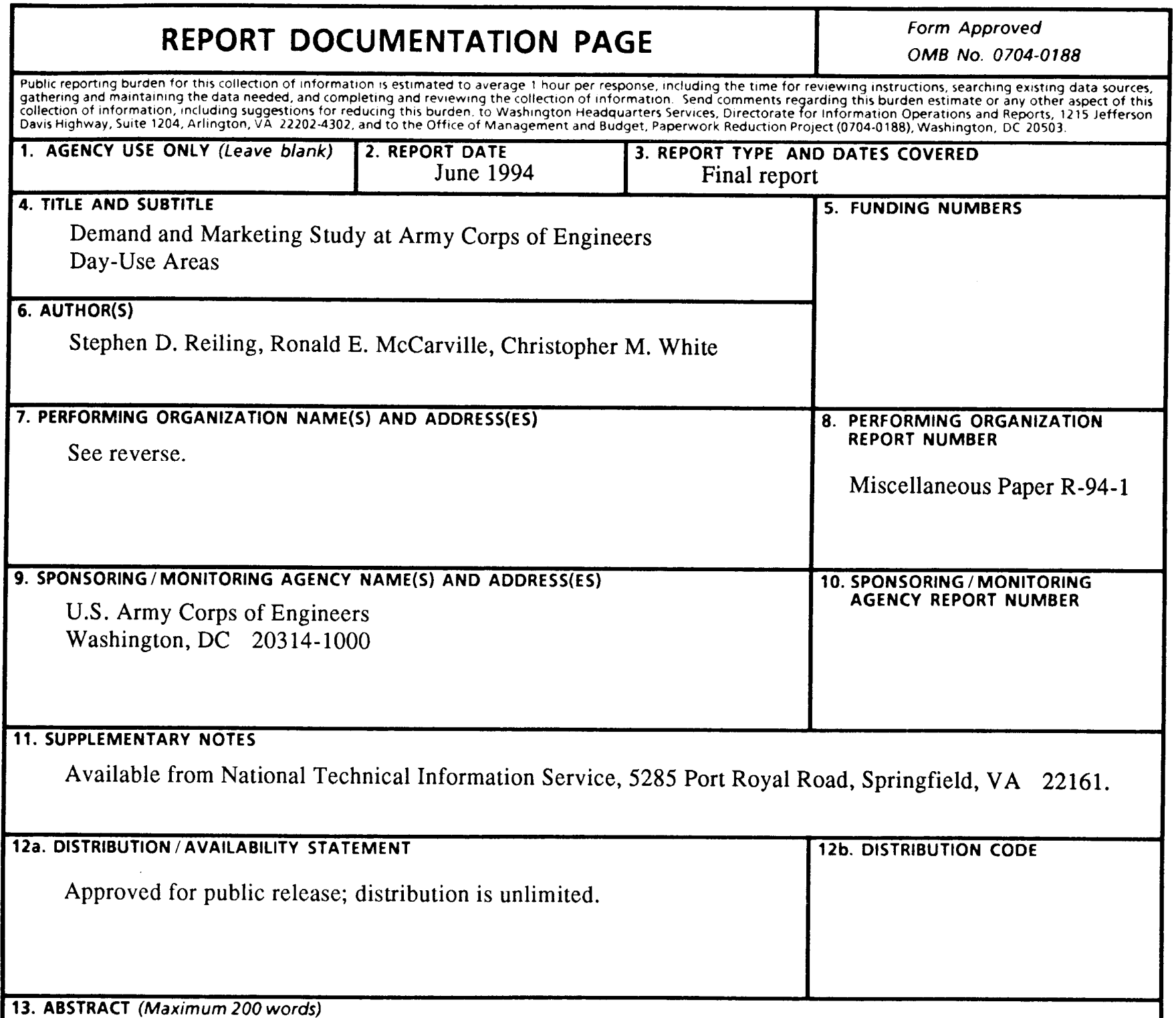

Increasing use of fees to offset declining appropriations has been an ongoing reality for the past 10 years. There are few studies that attempt to gather the impact this has on the users at Corps projects. This study developed marketing and demand information along with attitudinal measures related to fees for Corps day-use facilities (picnic areas, beaches, and boat ramps) from six Corps projects in different parts of the country. Revenue projections and fee impacts on population subgroups along with respondent motivations, attitudes, and expectations towards fees are provided along with recommendations concerning the implementation and level of fee for day-use facilities.

\begin{tabular}{|c|c|c|c|}
\hline \multirow{2}{*}{\multicolumn{3}{|c|}{$\begin{array}{l}\text { 14. SUBJECT TERMS } \\
\text { Attitudes } \\
\text { Fees } \\
\text { Marketing and demand studies }\end{array}$}} & \multirow{2}{*}{$\begin{array}{l}\text { 15. NUMBER OF PAGES } \\
106 \\
\text { 16. PRICE CODE } \\
\text { 20. }\end{array}$} \\
\hline & & & \\
\hline $\begin{array}{l}\text { 17. SECURITY CLASSIFICATION } \\
\text { OF REPORT } \\
\text { UNCLASSIFIED }\end{array}$ & $\begin{array}{l}\text { 18. SECURITY CLASSIFICATION } \\
\text { OF THIS PAGE } \\
\text { UNCLASSIFIED }\end{array}$ & $\begin{array}{l}\text { 19. SECURITY CLASSIFICATION } \\
\text { OF ABSTRACT }\end{array}$ & 20. LIMITATION OF ABSTRACT \\
\hline N 7540-01-280-5500 & & & $\begin{array}{l}\text { dard Form } 298 \text { (Rev. 2-89) } \\
\text { bed by ANSI Std. Z39-18 } \\
02\end{array}$ \\
\hline
\end{tabular}




\section{7. (Concluded).}

Department of Recreation and Leisure Studies, University of Waterloo, Waterloo, Ontario N2L 3G1; Department of Resource Economics and Policy, University of Maine, Orono, ME 04469-5782;

U.S. Army Engineer Waterways Experiment Station, Environmental Laboratory, 3909 Halls Ferry Road, Vicksburg, MS 39180-6199 
Destroy this report when no longer needed. Do not return it to the originator. 